\title{
INTERNATIONAL AND U.S. OBLIGATIONS TOWARD STOWAWAY ASYLUM SEEKERS
}

\section{BEATE ANNA ORT $\dagger$}

The day was Sunday, June 4, 1939, when a German Liner, the St. Louis, cruised off Miami Beach. On board were 907 Jewish refugees from Nazi Germany. The ship was surrounded by vessels of the U.S. Coast Guard to prevent any attempts by the refugees to reach the shore, and also to rescue any attempted suicides. The crew and refugees were waiting for $a$ decision by President Roosevelt on their request for political asylum. The request was refused and the ship returned to Europe. The German captain, more humanitarian than the President of the United States, allowed them to land in Holland, Belgium, France, and Britain. A year later, the Nazis invaded Holland, Belgium, and France and half of the refugees died in concentration camps. ${ }^{1}$

A stowaway ${ }^{2}$ asylum seeker denied an adequate opportunity to assert her claim can be returned to her country of origin where she may then face persecution and death, suffering a fate similar to that

† B.A. 1988, Harvard College; M.A. Foreign Affairs 1989, University of Virginia; J.D. Candidate 1992, University of Pennsylvania. This Comment is dedicated to Ausma Grimes, Kim Pham Trang, and my parents, all inspirational refugees, and to John Short. Many thanks to Fernando Chang-Muy and Jeff Dillman, for sparking my interest in stowaways, and to Professors Roger Clark, David Martin, and Gerry Neuman, for kindling this interest with their insightful commentary. The time and support of Alexei Cowett, Teri Firmiss, Larry Frankel, Felicia Listwa, and Blake Rhodes was also much appreciated.

${ }^{1}$ Haitian Detention and Interdiction: Hearing Before the Subcomm. on Immigration, Refugees, and International Law of the House Comm. on the Judiciary, 101st Cong., 1st Sess. 122 (1989) [hereinafter Haitian Interdiction Hearing] (statement of Msgr. Bryan O. Walsh, Executive Director, Catholic Community Services).

2 While stowaways also arrive on airplanes, this Comment addresses the problems specific to shipboard stowaways. Since 1989, the Immigration and Naturalization Service (INS) has classified "as a stowaway any alien who lacks proof that he or she was admitted on an airplane and paid for the flight." LAWYERS COMM. FOR HUMAN RIGHTS, THE IMPLEMENTATION OF THE REFUGEE ACT OF 1980: A DECADE OF EXPERIENCE 80 (1990) [hereinafter A DECADE OF EXPERIENCE]. Significantly, vessel and airplane stowaways are in very different situations upon their arrival in the United States. Airline carriers usually detain aliens classified as stowaways at hotels near the airport. See, e.g., id. at 80-81. Because airplanes must immediately be readied for use by other passengers, it is not feasible to detain stowaways on board. Vessel stowaways, on the other hand, are not routinely permitted off their vessels; they are detained on board until return transportation can be arranged. 
of the St. Louis passengers. Though many will escape death, often "stowaway asylum-seekers have been confined for many weeks and even months on board ship travelling from one port to another." Because records are incomplete, ${ }^{4}$ it is impossible to determine how many stowaways are landing in the United States or to trace the ultimate fate of those rejected at the border. It is known that between 1892 and 1988, 16,300 stowaways were apprehended and excluded, or rejected. ${ }^{5}$ This number, however, obviously does not include those who evaded inspection or who were granted asylum.

This Comment addresses protection issues pertaining to stowaway asylum seekers. Section I discusses their treatment under United States law. Section II sets forth the problems with current shipboard screening procedures for stowaways, focusing on access to interpreters (II.B.1) and counsel (II.B.4) and on the obstacles during shipboard interviews of official bias (II.B.2.a) and asylum seeker reticence (II.B.2.b). These procedures are also compared to those used in the Haitian interdiction program (II.B.3). This section argues that, contrary to current practice, all stowaways should be automatically removed from their vessels and granted a hearing, or at least be granted access to an interpreter and to any counsel present. Section III details the involvement of the United Nations High Commissioner for Refugees (UNHCR) ${ }^{6}$ in U.S.

${ }^{3}$ Note on Stowaway Asylum-Seekers, U.N. HCR Executive Comm., 39th Sess., at 1, U.N. Doc. EC/SCP/51 (1988) [hereinafter Stowaway Asylum-Seekers]. The Executive Committee noted further that "[i]]n one instance, the individual concerned was kept on board for well over a year." Id.; see also On a Bahamas Cruise With No Way Ashore, N.Y. TIMES, July 13, 1987, at A13 ("Eight stowaways have been riding the high seas in a legal muddle, stuck for six days on a cruise ship that makes daily round trips between Miami and the Bahamas.").

${ }^{4}$ See Robert M. Jarvis, Rusting in Drydock: Stowaways, Shipowners and the Administrative Penalty Provision of INA Section 273(d), 13 TUL. MAR. L.J. 25, 48 n.115 (1988) (asserting that " $[\mathrm{i}] \mathrm{t}$ has never been possible to know just how many stowaways actually are landing in the United States"); see also infra note 258 (describing the difficulties in ascertaining the number of stowaways that arrive at U.S. shores).

5 See U.S. DEP'T OF JUSTICE, 1988 STATISTICAL YEARBOOK OF THE IMMIGRATION AND NATURALIZATION SERVICE 111 (1989).

${ }^{6}$ The UNHCR was established in 1951 to assist those displaced by World War II. Its mandate is to protect refugees and to find durable solutions for them through voluntary repatriation, local integration, or resettlement in a third country. The High Commissioner, both as a person and as an agency, "stands at the center of the structure of refugee protection and care." W.R. SMYSER, REFUGEES: EXTENDED EXILE 42 (1987). The agency now "occupies the wings of two large Geneva office buildings, has 80 delegates in offices around the world, and employs more than 1,500 regular staff personnel." Id.; see also infra notes 198-204 and accompanying text (discussing the status of the UNHCR under international law). 
stowaway cases and suggests possible improvements in this intervention. Section IV then discusses the rights of appeal available to stowaways. Section $\mathrm{V}$ assesses the impact of the suggested changes on current U.S. immigration procedures.

The Comment continues with a discussion in section VI of how the United States, once it implemented progressive measures toward stowaway asylum seekers, could then pressure other nations to assume similar obligations, for stowaways are a worldwide problem and an international responsibility. Subsection VI.A describes the dormant International Convention Relating to Stowaways and maintains that the United States could take the lead in securing international commitment to assisting stowaways by initiating the drafting of a new and more comprehensive International Convention Relating to Stowaways, and by backing its ratification. In subsection VI.B the special obligations that port states bear toward stowaways are outlined; subsection VI.C discusses the international role of the UNHCR in protecting stowaways; and subsection VI.D highlights the heightened duties that the international community owes to child stowaway asylum seekers. The conclusion sets forth possible amendments to U.S. and international stowaway procedures that incorporate the solutions suggested in the previous sections.

\section{THE EVOLUTION OF U.S. IMMIGRATION LAW REGARDING STOWAWAY ASYLUM SEEKERS}

\section{A. Stowaways as an Excludable Class under Immigration Law}

Through the Immigration Act of 1917, stowaways became excludable ${ }^{7}$ from admission into the United States, but the Secretary of Labor was given discretionary power to admit them if they were "otherwise admissible." ${ }^{8}$ As a result of the Act, 13,755 stowaways were excluded between 1921 and 1950. ${ }^{9}$ Even so, the Immigration and Naturalization Service's (INS) 1948 Annual Report listed stowaways as "one of the five major causes of an unusually

${ }^{7}$ Aliens apprehended at the border are placed into exclusion proceedings whereas aliens who have entered the United States (either legally or illegally) are entitled to deportation proceedings.

${ }^{8}$ See Immigration Act of 1917 , ch. $29, \S 3,39$ Stat. 874, 876 (codified at INA $\S 212,8$ U.S.C. $\$ 1182$ (1988)). To avoid complication, all immigration statutes will be referred to in the text by their INA (Immigration and Nationality Act) sections. A parallel citation to the United States Code will be included in the footnotes.

${ }^{9}$ See U.S. DEP'T OF JUSTICE, supra note 5 , at 111. 
heavy work load" and maintained that "legislation to authorize stowaways being detained on board and deported without ... hearings would make for better law enforcement and conservation of manpower." 10

In light of the INS's concern, Congress included stowaways among those aliens excludable under the 1951 Immigration and Nationality Act (INA). ${ }^{11}$ The legislative history of the Act explained that "[s]towaways are excluded absolutely, whereas at present, the Attorney General has discretionary authority to admit stowaways." ${ }^{12}$ Not only did the new INA eliminate the Attorney General's discretion in admitting stowaways, but it included provisions that denied stowaways the right to a hearing before a special inquiry officer ${ }^{13}$ and the right to appeal an exclusion decision to the Board of Immigration Appeals (BIA), ${ }^{14}$ the highest administrative immigration forum. ${ }^{15}$

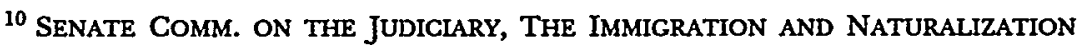
SYSTEMS OF THE UNITED STATES, S. REP. NO. 1515, 81st Cong., 2d Sess. 366 (1950) [hereinafter S. REP. NO. 1515] (quoting INS, ANNUAL REPORT 9, 27 (1948)); see also Revision of Immigration, Naturalization, and Nationality Laws: Joint Hearings on S. 716, H.R. 2379, H.R. 2816 Before the Subcomms. of the Comm. on the Judiciary, $82 \mathrm{~d}$ Cong., 1st Sess. 165 (1951) [hereinafter Joint Hearings] (statement of Richard Arens, staff director of the Subcommittee on Immigration and Naturalization of the Senate Committee on the Judiciary) (asking why it is "that the stowaway problem is one of the five greatest problems of the Immigration and Naturalization Service at the present time").

${ }^{11}$ See INA § 212(a)(18), 8 U.S.C. \$ 1182(a)(18) (1988) ("[T] aliens shall be ineligible to receive visas and shall be excluded from admission into the United States: . . (18) Aliens who are stowaways."). This provision was reenacted in the Immigration Act of 1990 , which states that "[a]ny alien who is a stowaway is excludable." Immigration Act of 1990, Pub. L. No. 101-649, § 601(a)(6)(D), 104 Stat. 5073 (to be codified at 8 U.S.C. $\$ 1182$ ). The new section applies to "individuals entering the United States on or after June 1, 1991." Id. \$601(e), 104 Stat. at 5077.

12 H.R. REP. No. 1365, 82d Cong., 2d Sess. 49 (1952), reprinted in 1952 U.S.C.C.A.N. 1653, 1703.

13 The term "special inquiry officer" is synonymous with "immigration judge." See 8 C.F.R. $§ 1.1(l)(1991)$. Immigration judges comprise one section of the Executive Office of Immigration Review (EOIR), which operates within the Justice Department, apart from INS. The EOIR is directly accountable to the Associate Attorney General.

14 The BIA is a five-member body which, along with the corps of immigration judges, makes up the Executive Office of Immigration Review (EOIR) in the Justice Department. The BIA primarily hears appeals from the exclusion and deportation decisions of immigration judges.

${ }^{15}$ See INA $\S 273(d), 8$ U.S.C. $\$ 1323(d)$ (1988). This section also imposed fines on carriers who failed to detain a stowaway aboard or who did not remove from the United States a stowaway on whorn an exclusion order had been imposed. See Jarvis, supra note 4, at 34 ("For many members of Congress, section 273(d) represented a means of deterring stowaways by regulating unscrupulous as well as careless shipowners."); Mary Mason, Alien Stowaways, the Immigration and Naturalization Service, 
It is revealing to compare the procedures afforded stowaways with those applied to other aliens. Section 235 of the INA grants immigration officers the authority to inspect all aliens seeking admission into the United States and to determine whether the alien is entitled to enter. ${ }^{16}$ INA $\S 235(\mathrm{~b})$ mandates that "every alien ... except as otherwise provided in ... [section] 273(d), who may not appear to the examining immigration officer at the port of arrival to be . . . entitled to land shall be detained for further inquiry to be conducted by a special inquiry officer. ${ }^{n 17}$ Under INA $\S 236(a)$, a special inquiry officer is granted "the authority in any case to determine whether an arriving alien who has been detained for further inquiry under section 235 shall be allowed to enter or shall be excluded and deported. ${ }^{18}$ Furthermore, an alien normally has the right to appeal a special inquiry officer's exclusion decision to the BIA. ${ }^{19}$

With respect to stowaways, however, INA § 273(d) explicitly states that " $[t]$ he provisions of section 235 for detention of aliens for examination before special inquiry officers and the right of appeal provided for in section 236 shall not apply to aliens who arrive as stowaways and no such alien shall be permitted to land in the United States. ${ }^{20}$ In sum, stowaways are summarily excludable under INA $\S 212(a)(18)$ and are denied permission to land under INA \& 273(d).

Although the INA does not define the term stowaway, a workable definition can be found in the statute that criminalizes stowing away, 18 U.S.C. $\$ 2199^{21}$ (entitled "Stowaways on vessels and aircraft"). This statute classifies as a stowaway anyone who,

and Shipowners, 12 TUL. MAR. L.J. 361, 365 (1988) (noting that $§$ 273(d) "specifically refer[s] to the duties [of shipowners] which are triggered by the discovery of an alien stowaway"); see also CHARLES GORDON ET AL., 3 IMMIGRATION LAW AND PROCEDURE $\$ 9.13$ (1991) (stating that the failure to detain stowaways aboard until inspection triggers an absolute liability in that the carrier will be subject to penalties "even though it had no knowledge of the stowaway's presence until he was apprehended in the United States ... [and] even though every precaution was taken" (footnote omitted)).

${ }^{16}$ See INA $\S 235,8$ U.S.C. $\S 1225$ (1988).

17 Id. \$ 235(b), 8 U.S.C. \$ 1225(b).

${ }^{18}$ Id. $\$ 236(\mathrm{a}), 8$ U.S.C. $\$ 1226(\mathrm{~b})$.

${ }^{19}$ See id. $\$ 236(\mathrm{~b}), 8$ U.S.C. $\$ 1226$ (b) ("From a decision of a special inquiry officer excluding an alien, such alien may take a timely appeal to the Attorney General .... "). Recall that the BIA operates under the auspices of the Attorney General. See supra notes 13-14.

20 INA $\S 273(d), 8$ U.S.C. $\$ 1323(d)$ (1988).

21 U.S.C. $\$ 2199$ (1988). 
"without the consent of the owner... or person in command of any vessel, ... [ [and] with intent to obtain transportation, boards, enters or secretes himself aboard such vessel." 22 Many courts have used this definition or a similar one requiring intent to stow away. ${ }^{23}$

There are persuasive reasons for according stowaway asylum seekers the right of disembarkation. When the INA was proposed, the Association of Immigration and Nationality Lawyers feared that $\S \S 212(a)(18)$ and 273(d) "did not allow full and fair hearings for stowaways and vested judicial or quasi judicial powers 'in the prosecutor or the immigration policemen." 24 When they are not permitted ashore stowaways essentially become prisoners aboard their vessels and face a high risk of being returned to persecution. Thus, "although limited in overall numbers, [they] constitute a major protection concern [for the UNHCR]." ${ }^{25}$ It is, therefore, important to assess whether the United States is satisfying its obligations toward stowaway asylum seekers.

\section{B. United States Obligations Toward Asylum Seekers}

Juxtaposed against the limited rights of stowaways is the United States obligation, under treaty and statute, of non-refoulement. By ratifying the 1967 Protocol Relating to the Status of Refugees, ${ }^{26}$

${ }^{22} \mathrm{Id}$. This provision imposes a fine of "not more than $\$ 1,000$ or imprison[ment] not more than one year, or both" for stowing away. Id. However, "only a very small percentage of arrests of aliens are intended or expected to lead to criminal prosecutions." INS v. Lopez-Mendoza, 468 U.S. 1032, 1043 (1984). The INS mainly focuses its attention on the removal of aliens.

${ }^{23}$ See United States ex rel. Candreva v. Smith, 27 F.2d 642, 644 (7th Cir. 1928) (defining stowaway as "one who conceals himself aboard an outgoing vessel for the purpose of obtaining free passage"); United States ex rel. D'Amato v. Williams, 193 F. 228, 230 (S.D.N.Y. 1909) (defining a stowaway as "one who steals his passage"); In $r e \mathrm{M} / \mathrm{V}$ "South African Victory," 12 I. \& N. Dec. 253, 256 (B.I.A. 1967) (finding longshoremen who boarded vessel in search of food and then fell asleep not to be stowaways); In re S.S. Maria Angela Martinoli, 1961 American Maritime Cases 1581 (B.I.A. 1960) (holding that a longshoreman who accidently fell asleep aboard a vessel was not a stowaway because of a lack of necessary intent to remain aboard); see also BLACK's LAW DICTIONARY 1421 (6th ed. 1990) (defining stowaway as "[o]ne who conceals himself aboard an out-going vessel or aircraft for the purpose of obtaining free passage").

${ }^{24}$ S. REP. No. 1515, supra note 10, at 366 (quoting testimony of a representative of the Association of Immigration and Nationality Lawyers).

${ }^{25}$ Stowaway Asylum-Seekers, supra note 3, at 1; $c f .2$ INT'L J. REFugEE L. 298 (1990) (reprinting a resolution of the General Assembly wherein particular concern for the safety and welfare of stowaway asylum seekers is expressed).

26 Protocol Relating to the Status of Refugees, Jan. 31, 1967, 19 U.S.T. 6223, 606 U.N.T.S. 267 [hereinafter 1967 Protocol]. The United States acceded to the 1967 
which incorporates the 1951 Convention Relating to the Status of Refugees, ${ }^{27}$ the United States agreed to abide by Article 33 of the 1951 Convention. This Article states that " $[\mathrm{n}] \mathrm{o}$ Contracting State shall expel or return ('refouler') a refugee ... to the frontiers of territories where his life or freedom would be threatened on account of his race, religion, nationality, membership of a particular social group or political opinion. ${ }^{28}$

The Refugee Act of $1980,{ }^{29}$ obligated the Attorney General to

Protocol on November 1, 1968. See M.J. Bowman \& D.J. HaRRIS, MulTtLateral TREATIES: INDEX AND CURRENT STATUS 307 (1984) (volume updated annually).

${ }^{27}$ See 1967 Protocol, supra note 26, art. I, para. 1, 19 U.S.T. at 6225, 606 U.N.T.S. at 268.

${ }^{28} 1951$ Convention Relating to the Status of Refugees, July 28, 1951, 189 U.N.T.S. 150 [hereinafter 1951 Convention]. Another treaty that prevents the United States from returning people to persecution is the Convention Against Torture and Other Cruel Inhuman or Degrading Treatment or Punishment, Dec. 10, 1984, 23 I.L.M. 1027, 24 I.L.M. 535 [hereinafter Torture Convention] (adopted by U.N. General Assembly as G.A. Res. 39/46, U.N. GAOR, 39th Sess., Annex, Agenda Item 99, U.N. Doc. A/RES/39/46 (1984)). The U.S. Senate ratified the Convention on October 27, 1990. See 136 CoNG. REc. S17,491-92 (daily ed. Oct. 27, 1990). Legislation implementing the Torture Convention is pending in Congress. It is part of the Omnibus Crime Control Act of 1991. See 137 CoNG. REC. S3209, S3237 (daily ed. Mar. 13, 1991).

Article 1 of the Torture Convention defines torture as "any act by which severe pain or suffering, whether physical or mental, is intentionally inflicted on a person ... when such pain or suffering is inflicted by or at the instigation of or with the consent or acquiescence of a public official." Torture Convention, supra, 23 I.L.M. at 1027. Paragraph 1 of Article 3 is critical in the refugee context. It mandates that "[n]o State Party shall expel, return ('refouler') or extradite a person to another State where there are substantial grounds for believing that he would be in danger of being subjected to torture." Id. at 1028. Paragraph 2 clarifies that "[f]or the purpose of determining whether there are such grounds, the competent authorities shall take into account all relevant considerations including, where applicable, the existence in the State concerned of a consistent pattern of gross, flagrant or mass violations of human rights." Id. Therefore, if a stowaway alleges that she fled from a country with a poor human rights record, the authorities must investigate to determine if there are substantial grounds for believing the stowaway could be subject to torture if denied entry into the United States.

${ }^{29}$ Pub. L. No. 96-212, 94 Stat. 102 (codified as amended in scattered sections of 8 U.S.C.). This Act was the implementation mechanism for United States obligations under the 1967 Protocol. The Act was hailed for establishing "a permanent and systematic procedure for meeting the humanitarian needs of refugees and those seeking asylum in the United States." 46 Fed. Reg. 45,116 (1981). The House Report stated that the Act was establishing "for the first time a provision in Federal law specifically relating to asylum" so as "to insure a fair and workable asylum policy which is consistent with this country's tradition of welcoming the oppressed of other nations and with our obligations under international law." HOUSE COMM. ON THE JUDiciary, THe Refugee ACT OF 1979, H.R. ReP. No. 608, 96th Cong., 1st Sess. 17-18 (1979). 
establish a procedure for an alien ... at a land border or port of entry, irrespective of such alien's status, to apply for asylum, and the alien may be granted asylum in the discretion of the Attorney General if the Attorney General determines that such alien is a refugee within the meaning of section $101(\mathrm{a})(42)(\mathrm{A}) .^{30}$

This Act's definition of "refugee" tracked the language of the 1951 Convention. A refugee is defined as any person who has "a well-founded fear of persecution on account of race, religion, nationality, membership in a particular social group, or political opinion. ${ }^{31}$ A corps of specially trained asylum officers has initial jurisdiction over asylum applications "filed by an alien physically present in the United States or seeking admission at a port of entry. $" 32$

Once exclusion or deportation proceedings ${ }^{33}$ have commenced, asylum claims are considered to be requests for withholding of exclusion or deportation under $\S 243(\mathrm{~h})$ and are heard by an immigration judge. ${ }^{34}$ If an alien initially is denied asylum by an asylum officer, she can renew her request before an immigration judge in the exclusion or deportation proceeding. ${ }^{35}$ While INA $\S 208$ makes granting of asylum discretionary, INA $\S 243(\mathrm{~h})$ mandates withholding of deportation of refugees. ${ }^{36}$ Thus, both

${ }^{30}$ Refugee Act of 1980, Pub. L. No. 96-212, § 201(b), 94 Stat. 102, 105 (codified at INA $\S 208(a), 8$ U.S.C. \$ 1158(a) (1988)). An alien can apply for discretionary asylum under $\S 208$ if the INS has not yet initiated deportation or exclusion proceedings against her. Once such proceedings have been initiated, her application will automatically be considered under $\S 243(\mathrm{~h})$. See infra notes 32-35 and accompanying text.

31 Refugee Act of 1980, § 201(a), 94 Stat. at 102 (codified at INA § 101(a)(42)(A), 8 U.S.C. $\$ 1101$ (a)(42)(A) (1988)). For the treaty definition of "refugee," see 1951 Convention, supra note 28, art. 1(A)(2), 189 U.N.T.S. at 152, amended by 1967 Protocol, supra note 26, art. 1, para. 2, 19 U.S.T. at 6224, 606 U.N.T.S. at 268.

328 C.F.R. $\$ 208.2(a)$ (1991). The asylum officer position was created in July 1990. The officers are attached to the Office of Refugees, Asylum, and Parole (CORAP) within the INS. See 8 C.F.R. § 208.1(b) (1991).

${ }^{33}$ For the distinction between these proceedings, see supra note 7 .

${ }^{34}$ See 8 C.F.R. $\$ 208.2(b)$ (1991).

${ }^{35}$ See id.

${ }^{36}$ Refugee Act of $1980, \S 203(\mathrm{e}), 94$ Stat. at 107 (codified at INA $\S 243(\mathrm{~h}), 8$ U.S.C. $\$ 1253(\mathrm{~h})(1988)$ ) ("The Attorney General shall not deport or return any alien ... to a country ... [where her] life or freedom would be threatened."). The Act revised this section by imposing an obligation on the Attorney General to withhold deportation; this had previously been left to the Attorney General's discretion. See 8 U.S.C. $\$ 1253(\mathrm{~h})$ (1976) ("The Attorney General is authorized to withhold deportation of any alien ....").

Another critical difference between application for asylum under $\S 208$ and withholding of deportation under $\S 243(\mathrm{~h})$ is the burden of proof to be satisfied by 
treaty and statute obligate the United States to offer haven, or asylum, to those who satisfy the refugee definition.

The disparity between INA §273(d), requiring summary exclusion of stowaways, and the 1967 Protocol and the Refugee Act of 1980, mandating protection for asylum seekers, posed a dilemma for immigration authorities. Because of the rights accorded under the Refugee Act, stowaway asylum seekers could apply for asylum to the district director at the port of entry. ${ }^{37}$ But while asylum applicants generally had the right to appeal the district director's decision to an immigration judge, ${ }^{38} \mathrm{INA} \S 273$ (d) denied this right to stowaways. 39

In a case involving two Chinese stowaways, however, the Second Circuit held that "the Refugee Act of 1980's asylum proceedings and [INA $\S 273(d)$ ] can be reconciled by allowing stowaways a hearing limited to the asylum claim, followed by whatever other procedural rights other asylum applicants are afforded. ${ }^{30}$ By limiting the hearing to the issue of asylum eligibility, the court reasoned that it was "preserv[ing] the basic thrust of [INA § 273(d)'s] command that stowaways are not entitled to exclusion hearings. ${ }^{n 11}$ The BIA refused to apply this case outside the Second Circuit, asserting that because stowaways are not entitled to an exclusion hearing, neither the immigration judge nor the Board had authority to consider a renewed application for asylum after a district director passed judgment on it. ${ }^{42}$ Two California district courts, however, did

the applicant. Those who can show a "well-founded fear of persecution" are eligible for asylum under $\S 208$. See INS v. Cardoza-Fonseca, 480 U.S. 421, 448-50 (1987). To qualify for the mandatory relief under $\$ 243(\mathrm{~h})$, the alien must demonstrate clear probability ("more likely than not") that she would be subject to persecution. See INS v. Stevic, 467 U.S. $407,429-30$ (1984).

${ }^{37}$ See 8 C.F.R. § 208.1(a) (1990); see also A DECADE OF EXPERIENCE, supra note 2, at 77-78 (noting that "[t]he INS has taken the position that aliens who stow away on U.S. vessels and who claim asylum when they are discovered by the crew may apply for asylum at the vessel's first United States port of call").

${ }^{38}$ See supra text accompanying notes $13,17-18$.

${ }^{39}$ See supra text accompanying note 20.

40 Yiu Sing Chun v. Sava, 708 F.2d 869, 876 (2d Cir. 1983).

${ }^{41} \mathrm{Id}$. at 876. The court based its decision on United States treaty obligations toward asylum applicants, the Refugee Act of 1980, and a procedural due process "interest in not being returned" to persecution. See id. at 877.

42 See In re Waldei, 19 I. \& N. Dec. 189, 191 (B.I.A. 1984). This case dealt with an Ethiopian stowaway who was denied asylum by the local district director. After this denial, the director instituted exclusion proceedings against the stowaway. The confusion in stowaway procedures even among INS officials is evidenced by the BIA's statement that "[ $t]$ he applicant, as an entrant stowaway, was not entitled to an exclusion hearing before an immigration judge and was therefore improperly placed 
follow the Second Circuit, granting stowaways the right to appeal their asylum claim to an immigration judge. ${ }^{43}$

In jurisdictions influenced by the BLA's reasoning, a stowaway was not entitled to appeal the district director's initial decision on her asylum claim and, thus, was not permitted to disembark from the vessel. ${ }^{44}$ The stowaway asylum seeker could leave the vessel only through a habeas corpus proceeding ${ }^{45}$ in district court, ${ }^{46}$

in exclusion proceedings by the Service." Id.

Our immigration system is so complicated that a federal circuit judge declared that ${ }^{\text {"[w] }}$ ]hatever guidance the regulations furnish to those cognoscenti familiar with [immigration] procedures, this court, despite many years of legal experience, finds that they yield up meaning only grudgingly and that morsels of comprehension must be pried from mollusks of jargon." Dong Sik Kwon v. INS, 646 F.2d 909, 919 (5th Gir. 1981), quoted in T. ALEXANDER ALEINIKOFF \& DAVID A. MARTIN, IMMIGRATION: PROCESS AND POLICY Xviii (1985).

${ }^{43}$ See Guo-Jun Cheng v. Ilchert, 698 F. Supp. 825 (N.D. Cal. 1988); Fang-Sui Yau v. Gustafson, 623 F. Supp. 1515 (C.D. Cal. 1985).

${ }^{44}$ See, e.g., Yiu Sing Chun, 708 F.2d at 871 ("While their applications [for asylum] were considered [by the San Francisco district director, before the vessel came within the jurisdiction of the Second Circuit,] the [stowaways] were confined on the 'American Lark,' en route to New York by way of Panama and Savannah, Georgia ....”). It was only when the stowaways reached New York that they were permitted to leave the vessel. See id.; see also Young Stowaways Ask Asylum From Ethiopia, N.Y. TIMES, Aug. 1, 1983, at B2 (noting that after initially being denied asylum in New York, two teenage stowaways traveled to numerous U.S. ports before finally being disembarked upon the vessel's return to New York).

45 See U.S. ConsT. art. I, § 9, cl. 2; see also BLACR's LAW DictionaRY 709 (6th ed. 1990) ("The primary function of the writ [of habeas corpus] is to release from unlawful imprisonment.").

${ }^{46}$ See INA $\S 106(\mathrm{~b}), 8$ U.S.C. $\$ 1105 \mathrm{a}(\mathrm{b})(1988)$ (" $[\mathrm{A}]$ ny alien against whom a final order of exclusion has been made ... under ... section 236 of this Act ... may obtain judicial review of such order by habeas corpus proceedings and not otherwise."). Although stowaways are excluded pursuant to INA § 273(d), not INA $\S 236$, "the clear intent of Congress in passing [INA § 106(b)] was to make petitions for habeas corpus the sole procedure for testing all decisions to exclude aliens, including those who are stowaways." Garcia v. Smith, 674 F.2d 838, 840 n.1 (11th Cir.) (holding that the district court had jurisdiction to hear the habeas corpus petition of a stowaway asylum seeker who had been excluded by the district director), modified on other grounds, 680 F.2d 1327 (11th Cir. 1982); see also House COMM. ON THE JUDICIARY, IMMIGRATION AND NATIONALITY ACT-AMENDMENTS, H.R. REP. NO. 1086, 87th Cong., 1st Sess. 30 (1961), reprinted in 1961 U.S.C.C.A.N. 2950, 2974 ("[H]abeas corpus shall be the sole and exclusive method for judicial review of an order excluding an alien from admission into the United States.").

It is well established that physical presence in the United States, "even under shipboard detention in the territorial waters, is sufficient to support the application of the constitutionally grounded writ of habeas corpus." David A. Martin, Due Process and Membership in the National Community: Political Asylum and Beyond, 44 U. PITT. L. REV. 165, 179 (1983). Although the United States has not ratified the 1982 U.N. Convention on the Law of the Sea, which states that the territorial sea can extend to 12 nautical miles from the baseline, see U.N. Convention on the Law of the Sea, Dec. 
which, in turn, could be initiated only after the district director's issuance of a final exclusion order. ${ }^{47}$

When ruling on a habeas petition, a court will consider "whether the statute, regulations, and the constitutional requirements of due process were observed, and whether the agency's action was arbitrary, capricious or an abuse of discretion." ${ }^{48} \mathrm{~A}$ federal court in habeas corpus proceedings can then issue "an order permitting the stowaway to leave the vessel to develop an asylum claim and may also issue an injunction preventing the stowaway from being transferred or removed [from its jurisdiction] during the pendency of the asylum case. ${ }^{\text {49 }}$

Nevertheless, the availability of habeas relief for a stowaway asylum seeker is far from certain. It depends entirely upon whether the stowaway can secure counsel to draft and file the petition, a difficult task given "the brief period that a vessel is usually in port." ${ }^{50}$ The vessel authorities will not delay departure to give the

10, 1982, pt. II, § 2, art. 3, 21 I.L.M. 1261, 1272 [hereinafter Sea Convention], President Reagan extended the U.S. territorial sea claim from three to twelve miles on December 27, 1988. See Proclamation No. 5928, 3 C.F.R. 547 (1988). Therefore, stowaways aboard vessels within twelve miles of the U.S. baseline can file for habeas corpus.

While habeas corpus is the only other legal means for a stowaway to leave a vessel if she is not initially permitted to disembark, she can escape from the vessel and swim to shore, entering the United States illegally. In this situation, the stowaway would have to be removed through deportation, not exclusion, proceedings because she has already entered the United States. See In re A-, 9 I. \& N. Dec. 356, 361 (B.I.A. 1961) (stating that a stowaway who escaped through porthole and swam to shore was entitled to deportation proceedings because she effected entry into the United States). Attempts by stowaways to swim ashore are not uncommon. See, e.g., Four Iranian Stowaways Jump From a Ship Into New York Harbor, N.Y. TimEs, Jan. 11, $1987, \S 1$, at 20 ("Four Iranians, stowaways on a freighter bound for Newark from Istanbul, were pulled from New York Harbor . . . after they jumped from the ship . . . ."); U.S. Recommends Denial of Asylum for Syrian, N.Y. TIMES, Dec. 11, 1985, at A23 ("The State Department recommended ... that asylum be denied to a Syrian ship stowaway who jumped handcuffed into the Mississippi River ....").

47 See INA $\S 106(\mathrm{~b}), 8$ U.S.C. $§ 1105 \mathrm{a}(\mathrm{b})$ (1988). The filing of a habeas claim does not hinge on whether a stowaway has already applied for asylum. Once a stowaway's presence is known to the INS, and before the stowaway even applies for asylum, a district director could summarily issue an exclusion order under INA § 212(a)(18), 8 U.S.C. $\$ 1182(a)(18)$ (1988). Therefore, the issuance of a final exclusion order does not necessarily mean that an asylum determination has already been made by the district director.

182 Immigration LaW and Procedure: Practice and Strategy § 30.06[1][c]

- (Gittel Gordon \& Charles Gordon eds., rev. ed. 1991).

49 P. Patrick Murphy \& Arthur R. Amdur, Crewmen, Passengers and Other Sojoumers: Pait I, IMMIGR. BRIEFINGS, June 1990, at 22.

${ }^{50} I d$. 
attorney an opportunity to file a habeas petition on behalf of the stowaway. Moreover, under INA § 106(c), an exclusion order "shall not be reviewed [through habeas proceedings] by any court if [the alien] has departed from the United States after the issuance of the order." ${ }^{51}$

A procedure in which the stowaway asylum seeker's rights depended on the fortuitous circumstances of the jurisdiction where the vessel landed and the availability of pro bono counsel hardly satisfied the United States obligation to those fearing persecution. In recognition of this, the INS promulgated a new rule regarding stowaway asylum seekers in the belief that this rule would "facilitate the adjudication of claims for asylum and withholding of deportation in a manner consistent with the Refugee Act of $1980 .{ }^{552}$

\section{The 1990 Rule Addressing Stowaway Asylum SEekers AND ITS DEFICIENCIES}

\section{A. Procedures Under the 1990 Rule}

The new rule revised 8 C.F.R. $\$ 253.1$ (f) to include stowaways; it previously addressed only alien crewmen alleging persecution. The regulation now states that any stowaway who "alleges that he cannot return to his country of nationality . . . because of fear of persecution ... is eligible to apply for asylum or withholding of deportation." ${ }^{.53}$ It mandates that "[i]f the alien is on a vessel or other conveyance and makes such fear known to an immigration inspector or other official making an examination on the conveyance, he shall be promptly removed from the conveyance. ${ }^{n 54}$ The alien must then be provided with application forms and given ten days to file an asylum application with the local district director..$^{55}$ The director must forward this application to the local asylum

5I INA § 106(c), 8 U.S.C. § 1105a(c) (1988).

52 Aliens and Nationality; Asylum and Withholding of Deportation Procedures, 55 Fed. Reg. 30,674, 30,679 (1990) [hereinafter New Reg.] (amending 8 C.F.R. $\S 253.1(\mathrm{f})$ ).

${ }^{53} 8$ C.F.R. § 253.1(f) (1991).

${ }^{54} \mathrm{Id}$. $\$ 253.1$ (f)(1) (emphasis added).

${ }^{55}$ See id. § 253.1(f)(2). 
officer. ${ }^{56}$ A negative decision by the asylum officer can be appealed directly to the BIA within ten days. ${ }^{57}$

\section{B. Problems with Shipboard Screening Procedures}

\section{The Necessity of an Interpreter During Initial Screening}

\section{a. The Complications of Securing Shipboard Interpreters}

According to the new rule, a stowaway will be removed from the vessel only if she "makes such fear [of persecution] known to an immigration inspector or other official making an examination on the conveyance. ${ }^{p 8}$ It is difficult to imagine how an exhausted and bewildered stowaway, with little or no knowledge of English, having spent days, if not weeks, on the vessel, would spontaneously make her fear of persecution known to an official.

The use of an interpreter would appear, at first glance, to be the simple solution. The United Nations High Commissioner for Refugees's Handbook on Procedures and Criteria for Determining Refugee Status, considers access to "the services of a competent interpreter" a fundamental。requirement for an asylum applicant. ${ }^{59}$ The UNHCR Handbook was published as a practical guide for " [g]overnment officials concerned with the determination of refugee status in the various Contracting States. ${ }^{760}$ It has been cited as persuasive authority in numerous fora, including the United States Supreme Court. ${ }^{61}$

Despite this authority, the INS has no regulation to ensure that a stowaway will be furnished with a qualified interpreter. Frequently a member of the crew is used as a translator, although the

${ }^{56}$ See id. The regulations created a corps of professional asylum officers "who are to receive special training in international relations and international law." Id. $\S$ 208.1(b); see also supra note 32; infra notes 97-98 and accompanying text (discussing the possible involvement of asylum officers in stowaway cases).

${ }^{57}$ See 8 C.F.R. \$ 253.1(f)(4) (1991).

${ }^{58} I d . \S 253.1(\mathrm{f})(1)$.

59 See UNITED NATIONS HIGH COMMISSIONER FOR REFUgEES, HANDBOOK ON Procedures and CrITERIA for Determining Refugee Status 192 (1979) [hereinafter UNHCR HANDBOOK].

${ }^{60}$ Ghassan M. Arnaout, Foreword to UNHCR HANDBOoK, supra note 59, at 1, 2.

${ }^{61}$ See, e.g., INS v. Cardoza-Fonseca, 480 U.S. 421, 438-39 (1987) ("In interpreting the Protocol definition of 'refugee' we are further guided by the analysis set forth in the [UNHCR Handbook]."); In re Rodriguez-Palma, 17 I. \& N. Dec. 465, 468 (B.I.A. 1980) ("The Handbook provides an interpretation of the meaning and application of the terms used in the Protocol."). 
individual often is not fluent in English and/or the stowaway's native language. ${ }^{62}$ Furthermore, a crewmember may speak but not be able to read the appropriate foreign language. This problem is critical should the stowaway have documents or identification that would help make her fear of persecution known to the official. INS regulations require that, in petitions or other documents submitted with an immigration form, "[a] foreign document must be accompanied by an English translation .... The translator must certify [that] he/she is competent to translate, and that the translation is accurate. ${ }^{\text {63 }}$ The assistance of a crewman translator in articulating an asylum claim may be of little avail to a stowaway unable to leave the vessel because of her inability to clarify documents that would make her fear of persecution known to the inspecting official. ${ }^{64}$

62 See Yiu Sing Chun v. Sava, 708 F.2d 869, 870 (2d Cir. 1983) ("When the ship arrived in California, each [stowaway] filed a Form I-589 applying for asylum. A Chinese-speaking employee of the shipping line, who neither was a lawyer nor spoke English well, helped [the stowaways] complete the forms."); Affidavit of Susan Douglas Taylor at 1-2, Record of the Unreported Case of Xiao Guangming [hereinafter Record] (on file with author) (stating that the Chief Officer, who acted as the interpreter during the stowaway's interview, told the attorney that he was Malaysian and "that though he speaks some Mandarin, he [did] not feel competent to perform this type of interpretation ${ }^{n}$ ). The vessel's American shipping agent also told the attorney that the crewman was not fluent in Mandarin and was only able to communicate with the stowaway about basic matters and ideas. See Telephone Interview with Susan Douglas Taylor, Attorney for Xiao Guangming (Feb. 27, 1991) [hereinafter Taylor Interview] (interview notes on file with author). Furthermore, the two attorneys involved interviewed the crewman interpreter and "both had great difficulty understanding his English." $I d$. The attorney for the stowaway claimed that "the entire adjudication ... [ [was] marred by the faulty record established during [this first] interview," Id.

Only after Xiao Guangming had spent nearly a year in detention and after his attorney was forced to obtain a temporary restraining order staying the stowaway's detention did the BIA grant him a new hearing before an asylum officer. See Stowaway Gets New Hearing: Man Continues Quest for Political Asylum, SEATTLE TIMES, Mar. 17, 1991, at B6 [hereinafter Stowaway Gets Hearing]; Chinese Stowaways Freed From INS Detention Center, AGENCE FRANCE PRESSE, July 26, 1991, available in LEXIS, Nexis Library [hereinafter Chinese Freed].

638 C.F.R. \$ 103.2(b) (1991).

64 See, e.g., Record, supra note 62, at 3 (indicating that the stowaway's attorney, upon asking "what translations were used by the District Director," was told that the Bureau of Human Rights and Humanitarian Affairs (BHRHA), the office within the State Department that issues advisory letters on asylum applications, "probably had a translator"). It is unlikely that the crewmember who had difficulty interpreting during the screening interview, see supra note 62 , would have been capable of translating these documents. The attorney stated that despite numerous requests she had "never been served with the translations of the documents which were originally submitted, and were used by the Service in making the decision [to deny asylum] in this case." Record, supra note 62 , at 4. 
Given these problems, the presence of a qualified interpreter is critical and, thus, should be made mandatory. In fact, INS Operations Instructions state that "Service personnel should secure the assistance of qualified Service interpreters (including other officers, full-time or contract interpreters), whenever they experience difficulties in conducting an interview of an alien who lacks competency in English. ${ }^{.65}$

Even if the immigration inspector wishes to have an INS interpreter on hand to communicate with the stowaway during the short period of time the vessel is in port, the inspector may have difficulty determining what language the stowaway speaks. ${ }^{66}$ Moreover, simply arranging for an appropriate interpreter to meet the stowaway at port can be difficult. ${ }^{67}$

${ }^{65}$ Charles Gordon \& Stanley Mailman, Immigration LaW and Procedure: OPERATIONS INSTRUCTIONS OF THE IMMIGRATION AND NATURALIZATION SERVICE, aPp. 2, § OI 103.2b(1) (1991) [hereinafter OPERATIONS INSTRUCTIONS]. Moreover, “[i]f the alien appears to fail to comprehend questions, whether the interpreter has been provided by the alien or Service officers, the interview should be rescheduled for a later date." Memorandum from CORAP to Asylum Directors (Aug. 12, 1991), reprinted in 68 INTERPRETER RELEASES app. V at 1217, 1218 (Sept. 16, 1991) [hereinafter CORAP Memorandum].

It is noteworthy that the INS itself has recognized the importance of qualified interpreters. However, INS Operations Instructions "do not have the force of law, are furnished for the general guidance of service officers, and generally do not confer substantive rights." CHARLES GORDON \& STANLEY MAILMAN, IMMIGRATION LAW AND PROCEDURE § 3.24[2] (rev. ed. 1991).

${ }^{66}$ For example, many stowaways have been Ethiopian; because " $\mathrm{t}$ ] here are nearly 100 distinct languages, some of which have several dialects or less well-defined regional variations" in Ethiopia, 17 THE NEW ENCYCLOPEDIA BRTTANNICA Eastern Africa 820 (15th ed. 1990), it could be very difficult to discover quickly what language the stowaway speaks. Cf. COMMISSION ON SECURITY AND COOPERATION IN EUROPE, 100TH CONG., 1ST SESS., REPORT ON THE MIROSLAV MEDVID INCIDENT 10-19 (Comm. Print 1987) [hereinafter MEDVID INCIDENT] (detailing the difficulty harbor police in New Orleans had in determining the language spoken by a Ukrainian sailor who jumped ship and the problem border-patrol agents faced when the INS supervisor of interpreters in New York had no interpreters available). Although Medvid was a crewman, not a stowaway, given the similarities in time constraints, language barriers, and cursory questioning, his case is relevant in the stowaway asylum seeker context.

67 See MEDVID INCIDENT, supra note 66, at 14-15. The only Ukrainian interpreter the border-patrol agents were able to secure at 12:00 a.m. was a woman in New York. In regard to her telephone interview with the Ukrainian seaman, she stated: "It was not a good connection and the speaker telephone was not working properly." Id. Furthermore, the border-patrol agent "had some difficulty understanding [the interpreter] because of her heavy accent and admitted that his southern drawl probably gave her problems." Id. at 15; see also Political Asylum Procedures for Alien Crewmen: Hearings on Political Asylum Procedures for Alien Crewmen and How They Were Applied to a Soviet Seaman, Miroslav Medvid Before the Subcomm. on Immigration and Refugee Policy of the Comm. on the Judiciary, 99th Cong., 1st Sess. 31 (1985) [hereinafter 
An attorney is a potential interpreter during shipboard interviews. ${ }^{68}$ When an attorney is meeting the vessel and is willing and able to interpret, she should be permitted to participate in the shipboard screening. ${ }^{69}$ Recently implemented INS procedures state that "attorneys are not to act as interpreters, if they are also acting in the capacity of attorney, representative of the asylum applicant. ${ }^{70}$ Although these guidelines prohibit the attorney of record from serving the dual function of counsel and interpreter, the attorney can interpret if "a waiver of the attorney for the interview" is submitted. ${ }^{71}$ This policy suggests that the INS is not suspicious of the participation of legally-informed interpreters in asylum interviews; rather, the INS is probably most concerned with possible ethical conflicts for the attorney.

Shipboard interviews with stowaways, however, are not asylum interviews. They are only preliminary screening procedures through which immigration officials determine whether the stowaway should be disembarked to pursue an asylum claim. The concern for ethical conflicts need not be as great for shipboard interviews. The decision the immigration official makes after such an interview is not as comprehensive as the one made after a full-fledged asylum interview. The screening official is not adjudicating the stowaway's asylum claim. On the other hand, for the stowaway, screening interviews are vitally important; if the stowaway is not permitted to disembark there will be no asylum interview. Since any attorney serving as interpreter could do so under oath, ${ }^{72}$ when the attorney

Political Asylum Procedures for Alien Crewmen] (affidavit of Irene Padoch, the Ukrainian interpreter) ("I had difficulty hearing the INS officer, who appeared to be on the second phone. I had to repeat various questions and answers several times on numerous occasions. $)$.

${ }^{68}$ See supra notes $167-68$ and accompanying text (discussing how attorneys become involved in stowaway cases).

${ }^{69}$ But of. Record, supra note 62, at 1-2 (stating that a second attorney, a native speaker of Mandarin and a UNHCR appointee, was denied access during an interview in which a Malaysian crewmember, who was not fluent in Mandarin, served as interpreter. It was not until the next day that the INS granted the attorney permission to interview the stowaway, even though the attorney was present when the vessel arrived.).

${ }^{70}$ CORAP Memorandum, supra note 65, at 1217.

${ }^{71}$ See Attorneys May Not Interpret for Asylum Applicants, INS Says, 68 INTERPRETER RELEASES 1198, 1198 (Sept. 16, 1991) This means that the attorney interpreting could not concurrently serve as the attorney of record. See id. The attorney could assume primary responsibility for the case after the interview.

72 During asylum interviews the asylum officer must place the interpreter under oath and complete a "Record of Interpreter's Oath in Asylum Interview." See CORAP Memorandum, supra note 65, at 1219; cf. 8 C.F.R. $\$ 208.9$ (c) (1991) ("The Asylum 
of record is the only qualified interpreter at a screening interview, she should be permitted to interpret. ${ }^{73}$

To avoid ethical problems that may arise when an attorney acts as an interpreter, the best solution to the language barrier remains a third-party INS interpreter. This is particularly true because "an attorney should not have to wear two hats in order to ensure statutory due process and fundamental fairness. Such a requirement would serve to disadvantage the alien whose attorney must translate proceedings while at the same time zealously represent the client. ${ }^{74}$ Additionally, attorneys cannot always be relied upon to interpret because there is no reason "to believe that all members of the class will be represented by counsel, or that those who are represented will have attorneys who speak their language fluently." ${ }^{75}$ An attorney should be permitted to interpret as a last resort when no INS interpreter is available. The INS should not rely on pro bono counsel to be fluent in the relevant language or to bring her own interpreter. It is ultimately the duty of the INS to ascertain the stowaway's story in order to make an informed decision on the asylum application. ${ }^{76}$

In sum, the difficulties in securing an appropriate interpreter for a shipboard interview suggest that all stowaways should be

Officer shall have the authority to administer oaths...."). A similar procedure could be instituted for interpreters at shipboard screening interviews.

${ }^{73}$ INS guidelines for interpreters at asylum interviews should be followed when attorneys interpret. The INS instructions declare:

An asylum applicant shall be permitted to have an interpreter present during the interview if a Service interpreter is unavailable, or the interviewing officer does not have a strong working knowledge of the foreign language. The interpreter shall be placed under oath and directed to translate the applicant's statements literally.

Memorandum from Andrew J. Carmichael, Jr., Associate Commissioner Examinations to All Regional Commissioners, District Directors and Officers-in-Charge, reprinted in 61 INTERPRETER RELEASES app. I at 522, 523 (June 29, 1984).

74 El Rescate Legal Servs., Inc. v. Executive Office for Immigration Review, 727 F. Supp. 557, 563 (C.D. Cal. 1989), rev'd, No. 90-55292, 1991 U.S. App. LEXIS 18089 (9th Cir. Aug. 12, 1991). Plaintiffs in El Rescate have filed "a petition for a rehearing with suggestion for rehearing en banc." See District Court Had Jurisdiction to Hear Translation Case, Ninth Circuit Holds, 68 INTERPRETER RELEASES 1154, 1155 (Sept. 9, 1991).

${ }^{75}$ Id.

76 Even when a qualified interpreter is available, the attorney could still monitor the screening interview for accuracy. Under INS guidelines for asylum interviews, the asylum officers must permit the "attorney of record to comment in a cooperative manner and to further facilitate the process." CORAP Memorandum, supra note 65, at 1219. 
mandatorily disembarked from their vessels so immigration officials can avoid the time pressures of working under the ship's tight schedule and can search for interpreters during regular working hours. If procedures are not modified to allow immediate disembarkation of all stowaways, an INS interpreter should always be aboard the vessel with the immigration inspector to help determine whether a stowaway is making her fear of persecution known. The reasoning that courts have used to require interpreters at exclusion hearings before immigration judges is equally, if not more, applicable in this context. One court recognized that if the plaintiff understood English at the time, "he would have realized that his asylum application did not state his true claim. This in turn might well have induced him to place his complete claim on the record, particularly if he had understood that this was . . . his last opportunity to substantiate his claim. ${ }^{77}$ Given the possible finality of the shipboard encounter between an immigration official and a stowaway, the presence of an interpreter during the shipboard interview is just as important as during an exclusion hearing; if the stowaway does not adequately convey her fear of persecution she remains trapped on the vessel. The Second Circuit has recognized that " $[t]$ o erect barriers by requiring comprehension of English [frustrates] the inclusive aim of the U.N. Protocol and the intent of congress." 78 The procedures of asylum law therefore must accord with its purpose, since "errors stemming from lack of translation may lead to the alien's return to persecution." ${ }^{\text {" }}$

\section{b. Due Process and the Right to an Interpreter}

Due process requirements buttress the argument for mandating the presence of an interpreter during a shipboard screening interview. Traditionally, the Court has declared that "an alien seeking initial admission to the United States requests a privilege and has no constitutional rights regarding his application. ${ }^{800}$ There has, however, been movement away from this restrictive doctrine. It is now accepted that while some protected interests originate in the Bill of Rights, other "liberty or property interests

${ }^{77}$ Augustin v. Sava, 735 F.2d 32, 38 (2d Cir. 1984).

${ }^{78} \mathrm{Id}$. at $37-38$.

${ }^{79}$ El Rescate, 727 F. Supp. at 562-63.

${ }^{80}$ Landon v. Plasencia, 459 U.S. 21, 32 (1982); see also United States ex rel. Knauff v. Shaughnessy, 338 U.S. 537, 544 (1950) ("Whatever the procedure authorized by Congress is, it is due process as far as an alien denied entry is concerned."). 
may have their source in positive rules of law creating a substantive entitlement to a particular government benefit. ${ }^{n 1}$ In Yiu Sing Chun v. Sava, ${ }^{82}$ the Second Circuit asserted that an asylum seeker "may well enjoy some due process protection not available to an alien claiming only admission." 83 The court found a liberty interest in the right of non-refoulement, founded on the 1951 Convention and 1967 Protocol, and incorporated into domestic law through the Refugee Act of $1980 .{ }^{84}$ It also suggested a possible property interest "in the form of a right to petition for asylum. ${ }^{n 55}$

81 Augustin, 735 F.2d at 37; see also Wolff v. McDonnell, 418 U.S. 539, 558 (1974) ("We think a person's liberty is equally protected even when the liberty itself is a statutory creation of the State.").

82 708 F.2d 869 (2d Cir. 1983).

${ }^{83}$ Id. at 877 .

${ }^{84}$ See id. at $877 \mathrm{n} .25$. Such an expanded analysis is plausible under the Supreme Court's definition of liberty, which " $[\mathrm{w}]$ ithout doubt, . . . denotes not merely freedom from bodily restraint but also the right . . . generally to enjoy those privileges long recognized . . . as essential to the orderly pursuit of happiness by free men." Meyer v. Nebraska, 262 U.S. 390, 399 (1923). The Supreme Court reaffirmed this reasoning in Board of Regents v. Roth, 408 U.S. 564 (1972), concluding that " $[i] n$ a Constitution for a free people, there can be no doubt that the meaning of 'liberty' must be broad indeed." Id. at 572.

${ }^{85}$ Yiu Sing Chun, 708 F.2d at 877 n.25. The court noted several cases that recognized the right to apply for asylum, including Haitian Refugee Center v. Smith, 676 F.2d 1023, 1039 (5th Cir. Unit B 1982) (finding a constitutionally protected interest in the right to apply for asylum and the right to pro bono counsel), OrantesHernandez v. Smith, 541 F. Supp. 351, 380-81 (C.D. Cal. 1982) (granting a preliminary injunction ordering INS to notify detained Salvadorans of their right to apply for asylum and granting detainees a right to consult with counsel), and Nunez v. Boldin, 537 F. Supp. 578, 584-87 (S.D. Tex.) (granting a preliminary injunction ordering notice of asylum as a right to all Salvadorans and Guatemalans detained in Los Fresnos, Texas), appeal dismissed, 692 F.2d 755 (5th Cir. 1982). These cases did not, however, exclusively define the right to petition for asylum as a property interest; they also spoke of a liberty interest. See, e.g., Haitian Refugee Ctr., 676 F.2d at 1039 ("Whether this minimal entitlement be called a liberty or property interest, we think it is sufficient to invoke the guarantee of due process."); see also Orantes-Hernandez v. Meese, 685 F. Supp. 1488, 1507 (C.D. Cal. 1988) (holding that "the right to apply for political asylum ... [does] constitute a substantial liberty interest"), aff 'd sub nom. Orantes-Hernandez v. Thornburgh, 919 F.2d 549 (9th Cir. 1990).

Commentators have questioned the holdings of these cases. See, e.g., Martin, supra note 46, at 220-21 (noting that "courts should recognize that fairness is possible even in the absence of attorneys"); Note, Protecting Aliens from Persecution Without Overloading the INS: Should Illegal Aliens Receive Notice of the Right to Apply for Asylum?, 69 VA. L. REV. 901,929 (1983) (characterizing the "imposition of a notice requirement" as a judicial "inability to construct a more flexible remedy for the problem of coercion"). But see T. Alexander Aleinikoff, Aliens, Due Process and "Community Ties": A Response to Martin, 44 U. PITT. L. REV. 237, 259 (1983) ("W] $[$ hen the government conduct becomes so outrageous, so obviously unfair, federal judges will put a stop to it. In attempting to do so, however, they will not be able to simply add another 
The Second Circuit later elaborated by stating that due process protection may be especially important where a claim for withholding of deportation under $\$ 243(\mathrm{~h})$ is at issue. ${ }^{86}$

If stowaway asylum seekers warrant due process protection, it should be determined which protections they are entitled to. In making this determination, courts must weigh three factors: "the interest at stake for the individual, the risk of an erroneous deprivation of the interest through the procedures used as well as the probable value of additional or different procedural safeguards, and the interest of the government in using the current procedures rather than additional or different procedures. ${ }^{87}$

Regarding stowaway asylum seekers, their private interest often "implicates stakes that are off the charts-the highest possible." 88 At some point, however, the United States must be deemed to have satisfied its statutory and treaty obligations to asylum seekers, even if enhanced procedures produce an additional small amount of useful information. ${ }^{89}$ Providing an interpreter, however, would not merely yield minimal information; any meaningful communica-

flower in the garden of due process ... . [They] are forced to leap in with both feet, demanding costly and intrusive procedures ...."). For further discussion regarding the right to notice of the right to apply for asylum, see infra note 123. The importance of the above cases rests, for the moment, in their recognition that aliens' liberty and property interests are protected by the due process clause.

${ }^{86}$ See Augustin, 735 F.2d at 37 (distinguishing Jean v. Nelson, 727 F.2d 957 (11th Cir. 1984) (en banc), affd on other grounds, 472 U.S. 846 (1985), which declined to find a constitutional interest in the right to be granted asylum under INA $\S 208$ ). The Augustin court maintained that the mandatory nature of INA $\$ 243(h)$ warrants greater due process protection of the right to asylum. See id. For an illuminating analysis of these disparate holdings, see ALEINIKOFF \& MARTIN, supra note 42, at 70910. Due process protection can be critical for a stowaway applying for asylum at the district director level under $\S 208$ because the applicant may not be entitled to a $\S 243(\mathrm{~h})$ appeal to an immigration judge. See infra part IV.

87 Landon v. Plasencia, 459 U.S. 21, 34 (1982) (applying the three-prong balancing test enunciated in Mathews v. Eldridge, 424 U.S. 319 (1976), for due process in an immigration case involving an excludable alien).

${ }_{88}$ Martin, supra note 46 , at 190 . In evaluating asylum procedures, Martin noted that " $[\mathrm{n}] \mathrm{o}$ other adjudication in our legal system potentially subjects the individual to torture or summary execution." Id; see also Kovac v. INS, 407 F.2d 102, 108 (9th Cir. 1969) ("It is particularly important that an applicant for relief under section 243(h) have a reasonable opportunity to present his proofs, for the stakes are high.").

89 See Mathews v. Eldridge, 424 U.S. 319, 344 (1976) ( $[$ [P]rocedural due process rules are shaped by the risk of error inherent in the truth-finding process as applied to the generality of cases, not the rare exceptions."); see also Martin, supra note 46, at 223 ("[N]o procedural system, no matter how elaborate, is proof against error."). But see Aleinikoff, supra note 85, at 248-50 (arguing that increased procedural protections may be necessary to protect asylum applicants). 
tion without an interpreter is hard to imagine. INS Operations Instructions recognize that "[q]uality interpretation of interviews of applicants for immigration benefits is essential for the proper adjudications of their applications. ${ }^{n 0}$ The requirement that an INS interpreter be present at the initial screening of a stowaway would undoubtedly increase the accuracy of procedures.

Nonetheless, the "[g]overnment's interest in efficient administration of the immigration laws at the border also is weighty. ${ }^{n 1}$ Immediate and definitive shipboard asylum determinations engender efficiency. More elaborate screening procedures requiring the presence of an interpreter also would impose a fiscal burden on the INS. This burden could be decreased if all stowaways were disembarked and questioned through an interpreter at a time convenient for all the parties involved. ${ }^{92}$ The policies of automatic disembarkation and/or mandatory presence of an interpreter also would presumably increase the attractiveness of stowing away and thereby encourage aliens seeking entry into the United States to bypass overseas screening procedures. ${ }^{93}$ This development could generate an influx of marginal stowaway asylum applicants, raising administrative costs and decreasing the effectiveness of screening programs.

Yet because an interpreter serves as the linchpin in the initial screening of an asylum applicant, the benefits of INS interpreter services justify the added costs. An evaluation under the three part due process test militates toward the mandatory presence of an interpreter at all shipboard interviews, despite the admittedly weighty government interest in efficient screening procedures. The INS must make a good faith attempt to know the stowaway asylum

90 OPERATIONS INSTRUCTIONS, supra note 65 , OI $\$ 103.2 \mathrm{~b}(1)$.

91 Plasencia, 459 U.S. at $\mathbf{3 4 .}$

92 This would avoid the problem of trying desperately to contact an interpreter before the ship departs. The Medvid incident is testimony to these difficulties. See generally MEDVID INCIDENT, supra note 66.

${ }^{93}$ Overseas refugee programs are the alternative to asylum for those seeking acceptance by the United States. Beneficiaries of the overseas programs are selected by U.S. personnel abroad. See generally ALEINIROFF \& MARTIN, supra note 42, at 62038 (detailing the operation of U.S. overseas refugee programs). 
seeker's story to evaluate her situation intelligently; an interpreter is indispensable for such an informed determination. ${ }^{94}$

In conclusion, given the difficulty in securing an interpreter for a shipboard screening interview, U.S. treaty obligations to refugees and U.S. commitments under the Refugee Act can best be satisfied by disembarking all stowaways for a fair asylum determination. But if current procedures remain in place, the INS must supply an interpreter during the screening interview on the vessel or at least permit an attorney who is present and fluent in the relevant language to interpret under oath.

\section{The Pitfalls of Initial Screening by Immigration Officials}

Aside from the logistical nightmare of arranging for an interpreter to participate in a shipboard screening of a stowaway, there remain grave complications with conducting shipboard interviews, even if the INS does manage to bring an interpreter. Before implementation of the new rule, commentators had long urged the INS to reform its asylum procedures in light of "the multiple translational, cultural, and psychological factors affecting credibility determinations." 95 Under the new regulations, officials must promptly remove a stowaway asylum seeker after she makes her fear of persecution known. When an inspector, however, is forced hastily to determine if a stowaway has articulated a fear of persecution, two problems can arise to complicate the process: official bias and asylum-seeker reticence. Because of these formidable obstacles to a correct determination, the fate of stowaways

${ }^{94}$ Langston Hughes offers good reasons for always supplying interpreters for stowaway asylum seekers:

Refugee in America

There are words like Freedom

Sweet and wonderful to say.

On my heart-strings freedom sings

All day everyday.

There are words like Liberty

That almost make me cry.

If you had known what I knew

You would know why.

Langston Hughes, Selected Poems of LaNGston Hughes 290 (1959).

95 Neal P. Pfeiffer, Note, Credibility Findings in INS Asylum Adjudications: A Realistic Assessment, 23 TEX. INT'L L.J. 139, 151 (1988). 
should not be determined by the one official boarding the vessel; all stowaways should be permitted to disembark to file an asylum claim with the local district director.

\section{a. The Problem of Official Bias}

Under the new regulations, a stowaway must make her fear "known to an immigration inspector or other official making an examination on the conveyance." 96 Although not a full-fledged asylum interview, determining whether a stowaway is articulating a fear of persecution involves a critical credibility assessment. It is rather disconcerting that the same rule that recognizes the demanding and intricate nature of refugee determinations by establishing a special corps of professional asylum officers, ${ }^{97}$ allows for the definitive screening of stowaways by immigration officials who may have little or no experience with asylum cases. A stowaway's case will be heard by an asylum officer only if the stowaway is removed from the vessel and allowed to file an application for relief. ${ }^{98}$

Although the immigration official first encountering the stowaway on the vessel is to permit disembarkation if the stowaway makes a fear of persecution known and is not supposed to make credibility judgments, such subconscious assessments are almost inevitable in the pressured situation of a shipboard interview. While listening to a stowaway's story, the boarding INS officer may think the stowaway is not being honest and decide, on the spot, to refuse to allow her to disembark. There is a risk that decisionmakers may engage in "snap judgments" and fail to "make adequate allowance for cross-cultural difficulties." ${ }^{\text {"9 }}$ Even the presence of an interpreter cannot ensure that the credibility determination made by one individual is accurate. ${ }^{100}$

968 C.F.R. § 253.1(f)(1) (1991).

97 See Robert Pear, U.S. Issues Asylum Rules Praised as Fairer to Aliens, N.Y. TIMES, July 19, 1990, at A16.

${ }_{98}$ See 8 C.F.R. § 253.1(f)(2) (1991).

99 David A. Martin, Reforming Asylum Adjudication: On Navigating the Coast of Bohemia, 138 U. PA. L. REv. 1247, 1287 (1990); see also Aleinikoff, supra note 85, at 250 ("Immigration officials ... have, at times, demonstrated disturbing degrees of callousness and bias in evaluating asylum claims.").

100 Although the presence of an interpreter is indispensable to any accurate asylum determinations, it complicates credibility assessments because "when an applicant must rely on a translator, the [official's] perception of the applicant's behavioral cues may be hampered.” Pfeiffer, supra note 95, at 146. 
Commentators have noted several "obstacles to an undistorted interaction between asylum seeker and official. These include the cultural relativity of notions and concepts [and] different perceptions of time ${ }^{n 101}$ as well as cross-cultural differences in behavioral cues. ${ }^{102}$ With respect to the first obstacle, one commentator explains:

[t]he cultural relativity of words, notions and concepts, and, even more importantly, the lack of consciousness of these differences in perception, are major sources of misunderstandings in crosscultural communication. The problem certainly affects asylum procedure: Too often officials assume that the way they think is also the way the asylum-seeker thinks. ${ }^{103}$

Conceptions of family units, ${ }^{104}$ geography ${ }^{105}$ and country $^{106}$ vary among cultures. ${ }^{107}$ When an asylum seeker gives answers that do not comport with an immigration official's notion of these concepts, it may lead to a negative assessment of the asylum seeker's credibility. Cross-cultural communication may be further complicated by "the official's unintentional bias in interpreting the statements in the light of his own legal concepts ${ }^{\text {108 }}$ and political

101 Walter Kälin, Troubled Communication: Cross Cultural Misunderstandings in the Asylum Hearing, XX INT'L MIGRATION REV. 230, 231 (1986).

102 See Pfeiffer, supra note 95, at 145-46.

103 Kãlin, supra note 101, at 234.

104 The concept of atomized, core family units is foreign to many cultures in which extended family members or members of the same ethnic group are considered an integral part of the family unit. See BETTY YORBURG, FAMILIES AND SOCIETIES: SURVIVAL OR EXTINCTION? 124 (1983) ("Because of the importance of the mobility factor, the nuclear family ... predominates in hunting and gathering societies and in postindustrial societies. In horticultural and agricultural societies, the family is less mobile, or is immobile. It . . strives to maintain the extended structure as the cultural ideal.")

${ }^{105}$ See Kälin, supra note 101, at 234 (relating that a Turkish asylum seeker was denied asylum partly because he claimed to have hidden in the mountains surrounding his hometown when the immigration official knew there were no mountains in that area. Significantly, this Swiss official did not know that in Turkish, "the term 'mountain' also applies to hilly regions.").

106 Borders in many parts of the world are artificially drawn and divide members of the same ethnic group. See RICHARD SANDBROOK, THE POLITICS OF AFrICA's ECONOMIC STAGNATION 42 (1985) (describing African countries as "artificial entities" that were created by "European imperialists [who] paid no heed to cultural and linguistic criteria in carving out national boundaries").

107 See generally Kälin, supra note 101, at 234.

${ }^{108}$ Id. Commentators have noted, for example, the differences in procedure among legal systems: "[I]n certain non-Western societies it is important to let persons involved in legal procedures speak freely about issues which appear to be not directly relevant to the topic of the procedure[,]" $i d$. at 232, while in many Western countries 
views. Frequently, "[b]order patrol officers tend to regard persons requesting asylum from nations friendly to the United States . . . as illegal aliens attempting to gain time to establish a foothold in this country. ${ }^{\text {"109 }}$

Furthermore, the "culturally determined nature of self-image and self-perception" may interfere with the asylum seeker's ability to articulate an individualized fear of persecution. ${ }^{110}$ The expectation that a true refugee will admit she was singled out for persecution is founded upon a Western conception of individualism and self. ${ }^{111}$ Answering that conditions in her country do not affect her freedom more than that of the average citizen may only be an activist's "expression of a deep identification ... . with the fate of [her] suppressed people. ${ }^{\text {112 }}$ It does not necessarily mean that she does not have a well-founded fear of individualized persecution.

Because the conceptualization of "common sense" varies among cultures, it poses yet another obstacle in asylum interviews. ${ }^{113}$ The notion of "common sense" is value-laden and molded by the specific culture; as such, "the official's common sense is of limited value for understanding many of the realities in the asylum-seeker's country of origin. 1114

Differing perceptions of time, another culturally relative concept, can also obstruct a valid assessment of credibility. While a general timeframe regarding a stowaway's experiences may be necessary for understanding the asylum applicant's expression of fear of persecution, an immigration officer might expect exactness in dates and duration of experiences during a screening interview. A newly arrived stowaway, however, may not be able to provide detailed information immediately. Even if an asylum applicant does recall the timing of events, there is no universal perception of time. Each culture has its own measurement of time, which may be based on a calendar system or centered around the timing of specific events and activities. ${ }^{115}$ When pressed to give accurate dates

adjudicators expect applicants to discuss only issues relevant to the asylum claim, see id. at 232-33.

${ }^{109}$ Aleinikoff, supra note 85, at 250; see also Martin, supra note 99, at 1274-75 (noting the political biases of INS officials and of judges).

110 See Kälin, supra note 101, at 235.

111 See CLIFFORD GEERTZ, LOCAL KNOWLEDGE 59 (1983).

112 Kälin, supra note 101 , at 236.

113 See GEERTZ, supra note 111, at 75-76.

114 Kälin, supra note 101, at 236.

115 The attorney for the stowaway Xiao Guangming emphasized that inconsistency of dates in his asylum application should not have been part of the credibility 
corresponding to a Western calendar the asylum seeker faces a dilemma: "Either he or she admits being unable to answer or tries to meet the expectations of the official and guesses at dates which might not be accurate. In both cases the applicant risks being found lacking credibility." 116

The final obstacle to accurate cross-cultural communication is the confusion triggered by different verbal behavioral cues among cultures. Gaze patterns and the extent of eye contact, as well as speaking rate, pauses in speech, and expression of emotion, vary among cultures. ${ }^{117}$ If an asylum applicant's demeanor does not comport with an official's conception of model behavior, the applicant's credibility could be unjustly questioned.

Bias is, of course, not limited to border officials meeting vessels at port; it is impossible for anyone, including district directors, immigration judges, and even the newly trained asylum adjudicators to be culturally neutral. When there are several layers of procedure, however, the risk of faulty credibility assessments is at least reduced. Because asylum cases require training in refugee credibility screening, as well as in the conditions of various countries of origin, "'[i]t seems unreasonable to expect immigration officers acting alone to make such important and complex determinations." 118

Given that a subconscious assessment of the stowaway's credibility is almost inevitable, the weighty decision on an asylum claim cannot be left to the discretion of one official. It is "a fundamental premise of our jurisprudence that the decision of weighty matters should almost never be placed in the power of a single individual free from the control of a superior reviewing body." 119

assessment. The life of Chinese peasants operates around seasons and the lunar calendar. The attorney, who had spent extensive time in China, declared that more consistent dates would actually be more suspicious in the application. See Taylor Interview, supra note 62; see also Kälin, supra note 101, at 236-37 (stating that "time is not universally perceived, but members of different cultures have varying conceptions of time and its relevance").

${ }^{116} \mathrm{Kälin}$, supra note 101, at 237.

117 See Pfeiffer, supra note 95 , at 145-46.

118 Steven G. Scheinfeld, Note, Due Process Rights of Asylum Applicants Expanded to Include Stowaways: Yiu Sing Chun v. Sava, 50 Brook. L. REV. 751, 781 (1984) (quoting COMMITTEE ON FEDERAL LEGISLATION, THE ASSOCIATION OF THE BAR OF THE CITY OF NEW YORK, IMMIGRATION REFORM AND CONTROL ACT OF 1983, at 24 (1983)); see also UNHCR HANDBOOK, supra note 59, I 192 (stating that immigration officers should be required to refer asylum cases to a higher authority).

119 Developments in the Law-Immigration Policy and the Rights of Aliens, 96 HARV. L. REv. 1286, 1361 (1983) (quoting Hearings Before the President's Comm. on Immigration 


\section{b. The Obstacle of Asylum Seeker Reticence}

"[E]ven if we were confident that government officials were obeying the letter and spirit of our asylum laws, we should still be wary of friendly but informal procedures. ${ }^{n 120}$ It is possible that a stowaway asylum seeker will not understand what is at issue when an immigration inspector boards the vessel, particularly if there is no qualified interpreter available. ${ }^{121}$ Even if she does recognize the gravity of the situation, a stowaway unacquainted with U.S. immigration law will not realize that she must articulate a fear of persecution "on account of race, religion, nationality, membership in a particular social group, or political opinion." ${ }^{\text {122 }}$ Further-

and Naturalization, 82d Cong., 2d Sess. 1578 (1952) (prepared statement of Professors Louis Jaffe and Henry Hart, Harvard Law School)). The Medvid incident provides a useful illustration of this point. Even though the crewman Medvid had unhesitatingly told the interpreter that he wanted to apply for asylum, the Border Patrol agent felt no "need to contact any superior for advice in his Medvid decision since he believed . . . that Medvid was 'just another ship-jumper." MEDVID INCIDENT, supra note 66 , at 18. The INS officers believed that "Medvid simply feared returning to his ship, but did not desire asylum." Id. Medvid was forcibly returned to his vessel, despite INS regulations granting "immediate action" case status to Soviet asylum seekers. See Medvid ex rel. Jeziersky v. New Orleans Police Dept., 621 F. Supp 503, 506 (E.D. La. 1985) ("INS violated its own 'immediate action' procedures by initially summarily returning Mr. Medvid ....").

120 Aleinikoff, supra note 85, at 250.

121 See Sannon v. United States, 427 F. Supp 1270, 1275 (S.D. Fla. 1977) ("Asylum] claims may involve factual issues that go beyond those which can be decided fairly from short interviews with recently landed aliens, many of whom are physically exhausted and unfamiliar with the language."), vacated and remanded, 566 F.2d 104 (5th Cir. 1978).

1228 C.F.R. § 253.1(f) (1991); see also UNHCR HANDBOOK, supra note 59, I 46 ("The expressions 'fear of persecution' or even 'persecution' are usually foreign to a refugee's normal vocabulary. A refugee will indeed only rarely invoke 'fear of persecution' in these terms . . . ."). For example, when Medvid was asked why he had jumped ship, he responded that "there were many reasons which could not be told in a short time" but that he "wanted to live in an honest country." Political Asylum Procedures for Alien Crewmen, supra note 67, at 31; see also MEDVID INCIDENT, supra note 66, at 16-17; The Case of Miroslav Medvid: Hearing on H. Res. 314 Before the Comm. on Foreign Affairs and its Subcomm. on Europe and the Middle East, 99th Cong., 2d Sess. 1415 (1985) (testimony of Irene Padoch, INS interpreter) ( $[$ [T] here was no doubt that Miroslav Medvid wanted to defect ... . [H] was so positive that he would like to stay, he told me this is an honorable and honest country."); (f. Young Stowaways Ask Asylum from Ethiopia, supra note 44, at B2 (relating that after interviewing two stowaway boys, INS officials stated that the boys "did not request asylum during the interview," even though the stowaways later told the ship's engineer that they "feared for their lives and wanted to escape").

A statement by UNHCR's Director of International Protection demonstrates that Medvid's situation is not unique: "[T]he Convention saw the refugee as an individual who had a well-founded fear of persecution. Today's refugee movements are 
more, even though the immigration inspector may ask a stowaway if she wants to apply for asylum, the stowaway may not understand the meaning of asylum. ${ }^{123}$

somewhat different from what was envisaged in 1951. In particular, . . the reasons for leaving home are often complex, and are sometimes not simply the result of persecution." Safeguarding the Right of Asylum, REFUGEES, Dec. 1990, at 6 (statement of Michael Moussalli, UNHCR Director of International Protection); see also Martin, supra note 99, at 1275 ("[M]ost of those applying [for asylum] in the United States today were both drawn and driven, and they chose to come in response to a complex mix of political and economic considerations.").

${ }^{123}$ See MEDVID INCIDENT, supra note 66 , at 16 . The interpreter spoke directly with the border patrol agent and "said that Medvid was not very sophisticated and . . . did not really understand the phrase 'political asylum.' She said that in his own words, Medvid 'wants to live in an honest country,' but he does not know the magic formula, or the exact phrase to use." Id. Apparently, "[t]he INS officer became impatient and [told the interpreter] to ask whether [Medvid] wanted political asylum, because he could keep him here only under those circumstances. [The interpreter] asked him that and he unhesitatingly responded 'yes." Political Asylum Procedures for Alien Crewmen, supra note 67 , at 31 .

The Medvid incident calls into question how effective notice of the right to apply for asylum would be. INS has claimed that when aliens arrive at U.S. borders:

They are interviewed as to why they came here. If they have questions that would flag asylum claims such as fear of persecution upon being returned, they are identified. Those persons are told what their rights are; they are given a form telling them what their rights are. . . . They are told that they will be subject to an exclusion proceeding. ... They will have the official shot with the district director.

Caribbean Migration: Oversight Hearings Before the Subcomm. on Immigration, Refugees, and International Law of the House Comm. on the Judiciary, 96th Cong., 2d Sess. 225-26 (1980) (statement of David Crosland, Acting Commissioner, INS). This procedure of notifying only those aliens who allege persecution of their asylum rights mirrors the procedure for stowaways under the new rule; if the stowaway makes a fear of persecution known (and thereby flags an asylum claim) she is permitted off the vessel and is given an opportunity to present her case to the district director.

There has been much debate over whether the INS should notify all aliens of the right to apply for asylum. Several courts have granted this right to aliens from specific countries. See supra note 85. But see Ramirez-Osorio v. INS, 745 F.2d 937, 946-47 (5th Cir. 1984) (refusing to require that notice of the right to petition for asylum be given to all aliens); Jean v. Nelson, 727 F.2d 957, 983 (11th Cir. 1984) (en banc) (" $[N]$ either the Constitution nor the Refugee Act and its accompanying regulations require the INS to inform all potential applicants of their right to seek asylum." ), affd on other grounds, 472 U.S. 846 (1985); Medvid ex rel. Jeziersky v. New Orleans Police Dept., 621 F. Supp. 503, 507 (E.D. La. 1985) (holding that no right to notice of the right to apply for asylum exists). The INS has argued that blanket notice would engender a flood of frivolous claims which would create a severe administrative burden. One commentator has reasoned that "too many asylum applications may only bury the truth by straining INS resources and preventing careful assessment of individual claims." Note, supra note 85 , at 924 . On the other hand, notice without the protection of counsel could have little impact on the number of asylum seekers. See id. The latter effect is more probable in the stowaway context.

Given the relatively small number of stowaways, the INS would not be 
Even if a stowaway understands exactly what information the immigration officer is asking for she may still be unable to convey it during the limited time of a shipboard interview. Refugees cannot be expected to make their fear of persecution spontaneously known to an immigration official who boards their vessel. ${ }^{124}$ Asylum seekers have often had negative experiences with government officials in their country of origin. Because "[n]othing in their past experience prompts them to open up readily to strangers, particularly when speaking of highly sensitive events, ${ }^{n 125}$ stowaway asylum seekers may be apprehensive when questioned by U.S. immigration officials. ${ }^{126}$ For example, as

former members of political parties and groups which were illegal in their home countries, [political refugees] have deeply internalized the values of secrecy and suspicion toward outsiders; they were part of a social network largely founded on these values which were crucial for the success of the organization and the freedom and even survival of its members. ${ }^{127}$

overburdened if required to give stowaways notice. But notice of the right to apply for asylum would do little good if the stowaway were not granted a formal hearing. Like Medvid, a stowaway asylum seeker might not understand the concept of asylum nor have an adequate opportunity to articulate her claim aboard the vessel. Therefore, a thorough interview on land with a trained asylum adjudicator would be a more valuable procedural safeguard than the right to notice of the right to apply for asylum. During such a hearing, the burden would still be on the stowaway to substantiate her story, but she would at least be given a fair chance to do so.

${ }^{124}$ A case in point is In re Waldei, 19 I. \& N. Dec. 189 (B.I.A. 1984), where the stowaway arrived in New York on August 31, 1980 and then traveled to New Jersey and Miami aboard the vessel. Finally, when the ship arrived in New Orleans on September 11, 1980, "the applicant informed the immigration inspector who boarded his ship that he intended to apply for asylum." Id. at 190. That eleven days passed before the stowaway was able to convey his intent to an inspector raises the possibility that only after several encounters with U.S. officials did the stowaway realize that he must affirmatively request asylum; luckily, in his case, the vessel had not departed for a foreign destination.

125 Martin, supra note 99, at 1286; see also Aleinikoff, supra note 85, at 250 ("No matter how much goodwill the INS official displays, it is possible that bona fide asylum applicants will be suspicious of government authority and unwilling to readily disclose the factual basis of their claims.").

${ }^{126}$ See UNHCR HANDBOOK, supra note 59, II 46, 190, 198; AMNESTY INTERNATIONAL USA, REASONABLE FEAR: HUMAN RIGHTS AND UNITED STATES REFUGEE POLICY 30 (1990).

${ }^{127} \mathrm{Kanlin,} \mathrm{supra} \mathrm{note} \mathrm{101,} \mathrm{at} \mathrm{232.} \mathrm{A} \mathrm{further} \mathrm{problem} \mathrm{is} \mathrm{that} \mathrm{"[i]f,} \mathrm{in} \mathrm{the} \mathrm{course} \mathrm{of}$ the asylum hearing, [political refugees] perceive the interrogating official as not sharing their own ideology and political views, they are likely to be reserved and hesitant in the manner in which they express themselves and thus to present a fragmented and confusing story." Id. 
Contact with officials is only one among many causes for apprehension in the setting of a shipboard interview. Many asylum seekers are victims of culture shock; they are amidst a "bewildering, confusing, depressing, anxiety-provoking, humiliating, embarrassing and generally stressful' situation of persons who move from one culture to another." 128

Unfortunately, there is a phenomenon of even greater concern than confusion and anxiety among asylum seekers. The concern lies in the "virtual epidemic among . . . refugees of post-traumatic stress disorder [(PTSD)]."129 Immigration officials, not realizing that "many PTSD sufferers experience a numbing of emotional responses when remembering the [traumatic] event, ${ }^{130}$ may be skeptical when stowaway asylum seekers describe a grisly event "with little visible emotion." 131 An immigration official who is not aware of this numbing reaction may find the case so incredible as not to merit further consideration ashore-thus, condemning the stowaway to her vessel. Ironically, such a traumatized stowaway is precisely the sort of asylum seeker the United States most needs to protect from refoulement.

If a stowaway asylum seeker does not find the act of conveying her real story traumatizing, she may still be unable to convey a true account. There are several reasons why refugees might deliberately lie. They may alter their stories in "an attempt to meet the presumed expectations of the official." 132 Secondly, a stowaway

${ }^{128} I d$. (quoting Adrian Furnham \& Stephen Bochner, Social Difficulty in a Foreign Culture: An Empirical Analysis of Culture Shock, in CULTURES IN CONTACT 161, 171 (Stephen Bochner ed., 1982)); see also Pfeiffer, supra note 95, at 143 ("Because they are attempting to assimilate themselves into a new and confusing culture, asylum seekers may speak in an unconvincing manner."). The stressful setting can affect an asylum seeker's "ability to articulate effectively, accent and voice quality." Id. at 145 (footnotes omitted).

${ }^{129}$ Sandy Rovner, The Torture of the Refugee: Why Judges Don't Believe, WASH. POST, Sept. 2, 1986, Health section, at 10-11; see also Martin, supra note 99, at 1287 (" [P]osttraumatic stress disorder may . . . block consistent memory of past events."); Pfeiffer, supra note 95, at 149 ("PTSD may be especially prevalent among refugees.").

${ }^{130}$ Pfeiffer, supra note 95, at 145; see also Neal R. Holtan, When Refugees Are Victims of Torture, WORLD REFUGEE SURVEY: 1986 IN REVIEW (U.S. Comm. for Refugees) 24, 26 (1987) ("International agencies, governments, and individuals . . . should not assume that refugees will spontaneously talk about torture or even admit to having been victims.").

${ }_{131}$ See Rovner, supra note 129, at 10-11 (recounting how even refugee relief workers were perplexed at this phenomenon); see also Pfeiffer, supra note 95 , at 145 (asserting that some immigration officials expect the stowaway to be extremely distraught when describing a traumatic event).

132 Kälin, supra note 101, at 237. Kälin sets forth the example of Kurdish asylum 
asylum seeker is likely to have been denied asylum at various ports before arrival in the United States. She may conclude that her true story of persecution is not persuasive enough and alter her history. ${ }^{133}$ Such unsubstantiated claims can result in a negative assessment of credibility. Finally, because stowaway asylum seekers may be confronted with a dilemma between "the 'subcultural' duty to keep all activities of an illegal political group secret under all circumstances and the requirement of the Asylum Act to disclose all relevant facts, ${ }^{134}$ they may view the concealment of their true experiences as their only viable option.

The above obstacles impelling asylum seekers to hesitate before divulging true accounts of their experiences are further compounded by the cultural relativity of lie and truth. Anthropologists have found that lying often has cultural justifications. For example, "[l]ying is bound to be frequent in a culture much concerned with the preservation of status ... and dignity." 135 Such cultural conceptions may be difficult for an immigration official to fathom, and she may wrongly reject a potential asylum claim by "concluding that a genuine refugee would never lie and, indeed, would have no need to do so." 136

The many causes of asylum seeker reticence pose obstacles for constructive interaction between officials and stowaways. These obstacles highlight the need for asylum adjudicators who are sensitive to the possibility of cross-cultural misunderstanding and aware of diverse cultural perspectives. "It is important to avoid an atmosphere of intimidation ... which makes the already confused and anxious asylum-seeker even more nervous and unconvincing." 137

seekers who feared arrest because of their work for militant political parties in Turkey but "claimed ... that they were wanted for prohibited cultural activities." Id. Kälin concludes that the applicants probably believed that an asylum claim based on a fear of punishment for cultural activities had a greater chance for success. Id.

${ }^{133}$ A particularly vivid example of this phenomenon is that of a stowaway who was originally denied asylum in Taiwan after candidly recounting the true story of his activities in the People's Republic of China. Upon reaching the United States and being interviewed by U.S. officials, he altered the focus of his account to concentrate on his underground activities in Hong Kong, even though it was his activities in China that actually conveyed a well-founded fear of persecution. See Taylor Interview, supra note 62 .

${ }^{134}$ Kälin, supra note 101, at 237.

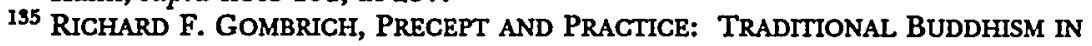
THE RURAL HIGHLANDS OF CEYLON 263 (1971).

${ }^{136}$ Kälin, supra note 101, at 238.

${ }^{137}$ Id. at 239. Kälin further suggests that, in order to breach the gap between 
These findings militate against the use of stowaway screening interviews conducted by border officials on vessels to which the bewildered and distraught stowaways have been confined for weeks; such encounters epitomize an intimidating setting. Furthermore, the officials involved at this early stage are unlikely to have extensive training in asylum adjudication. If "[o]nly an indistinct and difficult line separates those who should succeed on their asylum applications from those who should not, ${ }^{\text {138 }}$ a stowaway asylum seeker's fate should not hinge on one shipboard interview as it does under the new rule. Inconsistency between an asylum applicant's initial story and her application "may be found counterfactual or insubstantial upon administrative or judicial review. ${ }^{139}$ It is therefore crucial that all stowaways be immediately disembarked and permitted to apply for asylum before the local district director.

\section{Lessons from the Haitian Interdiction Program}

On the whole, the entire shipboard stowaway screening program envisioned through the new rule is ominously similar to the screening procedures that were in place until March 1, 1991 for asylum seekers under the United States-Haiti Interdiction Agreement. ${ }^{140}$ Under the Haitian interdiction program, the U.S. Coast Guard intercepts unflagged Haitian vessels bound for the United States and transfers their passengers to Coast Guard cutters. Prior to the recent policy revisions, INS officials conducted short

varying legal procedures, intervieuing techniques should allow "the asylum-seeker [to] determine what he or she regards as relevant statements." Id.

${ }^{138}$ Martin, supra note 99 , at 1275.

139 Arthur C. Helton, Credibility Determinations in Asylum Cases, 4 FED. IMMIGR. L. REP. 12, 13 (1986); see also Canjura-Flores v. INS, 784 F.2d 885, 889 (9th Cir. 1986) (finding the BIA's reliance on inconsistency in asylum seeker's testimony misplaced); Zavala-Bonilla v. INS, 730 F.2d 562, 566 (9th Cir. 1984) (concluding that, despite the BIA's decision to the contrary, the asylum seeker's testimony did "not contradict her asylum application statements").

${ }^{140}$ See Exchange of Letters Between Ernest H. Preeg, U.S. Ambassador to Haiti, and Edouard Francisque, Haitian Secretary of State for Foreign Affairs, Sept. 23, 1981, U.S.-Haiti, T.I.A.S. No. 10,241; Executive Order No. 12,324, 3 C.F.R. 180 (1982), reprinted in 8 U.S.C. $\$ 1182$ (1988). While the Haitian interdiction program and shipboard interviews of stowaway asylum seekers differ in that the Haitians are interdicted on the high seas and are not considered stowaways, they have sufficient similarities (both involving cursory interviews and a strained setting) to allow for a useful comparison. Documentation on the interdiction program contains insightful information on shipboard screening procedures and poignantly describes the problems of official bias and asylum seeker reticence. 
interviews with the passengers and if the interviewing officer was satisfied that an asylum claim had merit, the Haitian could be paroled into the United States for an exclusion hearing. ${ }^{141}$

The INS insisted that "[i]t should be clearly understood that the Service is not adjudicating asylum claims on the high seas but only making a preliminary determination as to whether an interdicted person may have a legitimate claim to political asylum that could be pursued once in the U.S.."142 Statistics, however, raise serious questions about this assertion. During the decade of the interdiction program, only six Haitians "have ever been found to have expressed a sufficient fear of persecution to be brought to the United States to pursue asylum"; ${ }^{\prime 43} 21,455$ interdicted Haitians were summarily returned to Haiti. ${ }^{144}$

In its study of the Haitian interdiction program, the Lawyers Committee for Human Rights found that the shipboard interviews "may not be private; the Haitians may be hungry, are definitely illat-ease and have no idea why they are being asked questions." ${ }^{145}$ The shipboard interviews may also have been insufficient because

[m]any refugees will only relate what happened to them to someone with whom they have established a relationship of trust and confidence.... [O]nly indirect probing will reveal whether the Haitian fears persecution in Haiti. Such indirect questioning has proven essential in eliciting information from refugees who ... are unable to express opinions and beliefs for which they have previously been made to suffer. ${ }^{146}$

Chilling similarities exist between the old interdiction procedures and those anticipated by the new rule for stowaway asylum seekers. ${ }^{147}$ Both sets of procedures require INS officials to oper-

141 See LAWYERS COMMTTTEE FOR HUMAN RIGHTS, REFUGEE REFOULEMENT: THE FORCED RETURN OF HATTIANS UNDER THE U.S.-HATTIAN INTERDICTION AGREEMENT 2022 (1990) [hereinafter REFUGEE REFOULEMENT]. Although these interviews were originally based on a questionnaire of 17 questions, a briefer 8 question version was introduced due to time constraints. See id. at 21-22.

142 Haitian Interdiction Hearing, supra note 1, at 29 (testimony of James L. Buck, Deputy Commissioner, INS).

${ }^{143}$ REFUGEE REFOULEMENT, supra note 141 , at 64 . Of the six that were brought to the United States, "two had lived in the United States before . . . and three were relatively well educated teachers able to articulate their claims." Id. at 23.

144 See id. at $24,64$.

$145 \mathrm{Id}$. at 22.

146 Id. at 23 (footnote omitted).

147 There are, of course, differences between stowaway asylum seekers and Haitian asylum seekers. The Haitian interviewees have the advantage of being provided with an INS interpreter. On the other hand, the Haitians face some obstacles that 
ate under severe time constraints and to make hasty determinations. And the screening INS officer in either situation theoretically is not to adjudicate the asylum claim aboard the vessel. The decade's statistics on admission of Haitians into the United States therefore bode ill for stowaway asylum seekers who are treated under the new rule's procedures.

In light of criticisms of the Haitian interdiction program, the INS adopted new procedures for the Alien Migrant Interdiction Program (AMIO) which went into effect on March 1, 1991. The interdiction procedures were "modified to include an opening presentation by the INS officer and his interpreter explaining the purpose of the ensuing interviews with INS."148 This affirmative step was found "necessary to overcome the overwhelmingly negative atmosphere resulting from the actual interdiction which immediately precedes the INS interviews." ${ }^{149}$ The Director of Asylum also issued a recommended twenty question interview questionnaire. ${ }^{150}$

Under these new procedures, "[i]f the alien asserts or even hints at past difficulties at home, or at a possible fear of returning home ... a more in-depth interview with the INS asylum pre-screening officer must be conducted to determine the extent and reasons of the fear and the credibility of the applicant." 151 The asylum prescreening officer "should be fully aware of the political, cultural, economic and social affairs of the interdicted alien's country of origin" and "should also be well-versed in asylum law and practice." 152 Interdicted aliens who express a "credible fear of returning home should be routed to the United States to formally pursue an asylum claim before an Asylum Officer." 153 The new proce-

stowaways might avoid. The Haitians venture to sea on tiny, overcrowded vessels, only to confront U.S. authorities who are not necessarily sympathetic toward asylum seekers from Haiti.

${ }_{148}$ Gregg A. Beyer, Procedural Changes in the INS Asylum Pre-Screening Component of the AMIO, Memorandum from Gregg A. Beyer, Director of Asylum, INS, to Leon Jennings, Chief, Asylum Pre-Screening Unit, and Erich Cauller, Director, Miami Asylum Office (Mar. 1, 1991), reprinted in 68 INTERPRETER RELEASES app. I at 804, 804 (1991) [hereinafter Procedural Changes].

149 Id.

150 See id. at 806-07.

${ }^{151}$ Id. at 804 (emphasis added). The Asylum Branch noted its awareness "of the increased burden the ... changes will place on Service interpreters aboard the cutters" and explained that it was considering "funding additional Unit interpreters." Id.

152 Id. at 805.

${ }^{153} I d$. 
dures explain that " $[\mathrm{t}]$ his standard (for transfer to the United States) is considerably less than the standard necessary to obtain asylum, but considerably more than the so-called 'frivolous'/'manifestly unfounded' threshold needed for employment authorization." 154

Unfortunately, the concerns addressed through the new policies for the interdiction program still plague the procedures for stowaway asylum seekers. The overwhelmingly negative atmosphere that surrounds interdiction typifies the environment surrounding a stowaway's first encounter with officials at the port of entry. It is highly unlikely that a stowaway will receive an explanatory presentation by an INS officer or an interpreter before the screening interview. Moreover, only if the stowaway asserts a fear of persecution will she be permitted to disembark; hinting at a possible fear is not sufficient to trigger an in-depth shipboard interview with a trained asylum officer and certified interpreter.

Lastly, while the interdiction procedures anticipate credibility determinations during the screening interviews and define the threshold for transfer to the United States as being considerably less than the standard necessary to obtain asylum, the regulations for stowaway asylum seekers do not even acknowledge that a credibility assessment is inherent in the initial encounter between a stowaway and an official. As a result, the stowaway procedures do not address the problem of overly hasty determinations. In sum, because the problems of the interdiction program echo concerns in the stowaway context, comprehensive procedures, such as those recently implemented for the interdiction program, should be promulgated for the screening of stowaways at U.S. ports.

These comprehensive procedures should, for the reasons previously discussed, include the mandatory disembarkation of all stowaways. Given the problems of official bias and asylum seeker reticence, the disparate levels of training in asylum adjudication among officials boarding the vessels, and the lack of review of their screening decisions, there exist grave risks that true refugeestowaways will not be let off their vessels and permitted to assert fully their asylum claims, but instead will be sent back to persecution. Even before the enactment of the Immigration and Nationality Act in 1952, the Association of Immigration and Nationality Lawyers had expressed concern about the summary exclusion of 
stowaways called for in INA $\S 212(a)(18) .{ }^{155}$ While the new rule marks clear progress from summary exclusion, the concern for appropriate stowaway procedures remains.

\section{The Presence of Counsel during Shipboard Interviews}

\section{a. Aliens and Access to Counsel}

In any exclusion hearing before an immigration judge, an alien has "the privilege of being represented (at no expense to the Government) by such counsel ... as he shall choose." ${ }^{156}$ The Sixth Amendment right to counsel granted to criminal defendants has not been accorded to aliens in deportation proceedings; courts maintain that these proceedings are civil, rather than criminal, in nature. ${ }^{157}$ Aliens can attempt to assert the right to appointed counsel under the due process clause of the Fifth Amendment, but this argument is likely to fail. ${ }^{158}$

Some courts, conceding that asylum seekers do not have the right to appointed counsel, have nonetheless held that due process mandates that the scheduling of exclusion hearings be tailored to the availability of pro bono counsel. ${ }^{159}$ In light of these holdings, commentators have noted that the current ban against appointed counsel "provides only illusory cost savings," given the expenses the

155 See supra note 24 and accompanying text.

156 INA § 292, 8 U.S.C. \$ 1362 (1988).

${ }^{157}$ See, e.g., INS v. Lopez-Mendoza, 468 U.S. 1032, 1038 (1984) (stating that a "deportation proceeding is a purely civil action"); Woodby v. INS, 385 U.S. 276, 285 (1966) (same).

${ }^{158}$ One court stated that an indigent alien might be entitled to governmentappointed counsel when "the assistance of counsel would be necessary to provide "fundamental fairness" but found in the specific case that lack of counsel had not breached such fundamental fairness. Aguilera-Enriquez v. INS, 516 F.2d 565, 568 (6th Cir. 1975) (quoting Gagnon v. Scarpelli, 411 U.S. 778, 790 (1973)), cert. denied, 423 U.S. 1050 (1976). Some commentators have argued that, given asylum seekers' precarious situations, all should have a right to appointed counsel. See Robert N. Black, Note, Due Process and Deportation-Is There a Right To Assigned Counsel?, 8 U.C. DAvis L. REV. 289, 306 (1975); Elizabeth Glazer, Note, The Right to Appointed Counsel in Asylum Proceedings, 85 ColUM. L. REV. 1157, 1185 (1985).

${ }^{159}$ See, e.g., Haitian Refugee Ctr. v. Smith, 676 F.2d 1023, 1039 (5th Cir. Unit B 1982) (" $[W]$ e hold simply that the government violates the fundamental fairness which is the essence of due process when it creates a right to petition and then makes the exercise of that right utterly impossible."); Louis v. Meissner, 530 F. Supp. 924 (S.D. Fla. 1981) (enjoining exclusion proceedings against Haitian asylum applicants until pro bono counsel became available), vacated, 532 F. Supp. 881 (S.D. Fla. 1982); see also Martin, supra note 46, at 220 (noting that these decisions have come "functionally closen $^{n}$ to requiring appointed counsel). 
government incurs during prolonged detention of an asylum seeker waiting for pro bono counsel to become available. ${ }^{160}$

A question that arises is what rights aliens have during prehearing interrogations. In the deportation context, if an alien is arrested without a warrant $t^{161}$ and brought in for questioning, she need not be advised of her rights under Miranda v. Arizona, ${ }^{162}$ until "[a]fter the examining officer has determined that formal proceedings ... will be instituted ...."163 Courts have justified this delay in issuing warnings by recalling that, in deportation proceedings, the alien bears the burden of proof to establish that she is entitled to remain in the United States. ${ }^{164}$ Furthermore, "the alien's silence may be used as the basis for drawing certain adverse inferences." ${ }^{n 165}$ Given these factors, courts have found that the administering of Miranda warnings prior to preliminary

${ }^{160}$ See Glazer, supra note 158, at 1184; Martin, supra note 99, at 1330; Martin, supra note 46 , at 220 . One solution is that government-paid attorneys be made available to asylum seekers, but because of budget constraints, this course is "politically unlikely." See Martin, supra note 99, at 1329-30. The best solution appears to be the crafting of an asylum adjudication system that is reliable, even without the involvement of counsel. See id. at 1350-51.

161 By statute the INS has the power to undertake certain actions without a warrant:

Any officer or employee of the Service ... shall have power without warrant-(1) to interrogate any alien or person believed to be an alien as to his right to be or to remain in the United States; (2) to arrest any alien who in his presence or view is entering or attempting to enter the United States in violation of any law or regulation made in pursuance of law regulating the admission, exclusion, or expulsion of aliens, or to arrest any alien in the United States, if he has reason to believe that the alien so arrested is in the United States in violation of any such law or regulation and is likely to escape before a warrant can be obtained for his arrest ....

INA § 287(a)(1)-(2), 8 U.S.C. § 1357(a)(1)-(2)(1988); see also supra note 22 (discussing how INS arrests primarily focus on effecting removal rather than prosecution).

162384 U.S. 436, 444 (1966) (holding that prior to any custodial interrogation, a criminal defendant "must be warned that he has a right to remain silent, that any statement he does make may be used as evidence against him, and that he has a right to the presence of an attorney").

1638 C.F.R. § 287.3 (1991). This regulation was instituted in 1979. See 44 Fed. Reg. 4654 (1979). Between 1967 and 1979, INS regulations required that an alien arrested without a warrant be immediately advised of her rights. See 32 Fed. Reg. 6260 (1967); ALEINIKOFF \& MARTIN, supra note 42, at 432.

${ }^{164}$ See United States v. Alderete-Deras, 743 F.2d 645, 648 (9th Cir. 1984); ChavezRaya v. INS, 519 F.2d 397, 401 (7th Cir. 1975); see also INA § 291, 8 U.S.C. $\$ 1361$ (1988) (allocating burden of proof to the alien).

165 Chavez-Raya, 519 F.2d at 401; see also United States ex. rel. Bilokumsky v. Tod, 263 U.S. 149, 154 (1923) (asserting that "there is no rule of law which prohibits officers charged with the administration of the immigration law from drawing an inference from the silence of one who is called upon to speak"). 
interrogation, "would be not only inappropriate but could also serve to mislead the alien." 166

\section{b. Stowaways and Access to Counsel During Shipboard Interviews}

The above analysis of alliens' rights serves as a useful backdrop for an assessment of a stowaway's right to counsel during shipboard interviews. Many attorneys involved in stowaway cases during the early stages aboard the vessel are contacted by the UNHCR and informed of the stowaway's impending arrival at a nearby port. The UNHCR asks the attorney to meet the vessel to ensure that the stowaway has the opportunity to make an asylum claim, if such a claim would be appropriate. Under the current procedures applicable to stowaways, the UNHCR finds it necessary to secure counsel for arriving stowaways because their disembarkation is not ensured. If the procedures were changed to permit all stowaways to disembark to assert their claims ashore, counsel would not be required aboard the vessel, for there would be no shipboard interview involved in the process. If the current procedures remain in place, however, access to counsel aboard the vessel will remain of paramount concern. Unfortunately, the pro bono attorneys appointed by the $\mathrm{UNHCR}^{167}$ are often dismayed when they go to meet the ship (sometimes in the middle of the night) and are denied access to the stowaway while the screening interview is conducted by the INS. ${ }^{168}$

${ }^{166}$ Chavez-Raya, 519 F.2d at 402; see also Trias-Hernandez v. INS, 528 F.2d 366, 368 (9th Cir. 1975) (endorsing the reasoning in Chavez-Raya). Courts have noted that the situation would be different if the statements had been coerced or if the statements were used in a criminal proceeding for violation of immigration laws. See Chavez-Raya, 519 F.2d at 400; Alderete-Deras, 743 F.2d at 648; see also ALEINIKOFF \& MARTIN, supra note 42 , at 433 (explaining that prior statements are sometimes excluded on due process grounds "where [the courts or the BIA] conclude that the circumstances surrounding the alien interrogation rendered the statements 'involuntary"').

${ }^{167}$ The pro bono attorneys are generally immigration law practitioners in the port city. Where a city's immigration bar is small and therefore unable to assist a stowaway, the UNHCR has secured attorneys from quite far away. The author experienced one such case during the summer of 1990, when two attorneys were willing to drive four hours to Morehead City, North Carolina to assist two Ethiopian stowaway children. The stowaways had previously been denied asylum in Philadelphia and had jumped overboard twice.

${ }^{168}$ See supra note 69 (relating incident in which access was denied to a UNHCRappointed attorney during an INS interview with a stowaway). In the case of the two Ethiopian teenagers in Morehead City, see supra note 167, an attorney who had served in the Peace Corps in Ethiopia was effectively denied access to the stowaways when 
In the Medvid case, ${ }^{169}$ in which a Ukrainian sailor jumped into the New Orleans harbor, pro bono counsel who had been denied access to the interviews argued that their own constitutional rights had been violated; they maintained that denial of access to their client infringed on their First Amendment right of political expression. ${ }^{170}$ The court found that, while plaintiffs had a First Amendment right to engage in such activity free from governmental interference, they did not have "an affirmative right to the Government's assistance in identifying and furnishing information to political clients." 171

The court also rejected plaintiff's argument that denial of access impeded their First Amendment right to associate. It reasoned that because the closed interview has a "specific and important governmental purpose," excluding "private citizens, so long as it is not selective and based upon the content of their views, is not a violation of the public forum doctrine. ${ }^{172}$ This reasoning may be based on the INS's desire to deter attorneys from chasing vessels. In their attempt to obtain publicity, such attorneys might delay asylum determinations.

This argument, however, is not viable in the stowaway context because the attorneys seeking access to shipboard interviews do not do so as private citizens. They are essentially UNHCR envoys, ${ }^{173}$ and should "enjoy such privileges and immunities as are necessary

the Coast Guard demanded payment of $\$ 400$ per hour for the attorney to access the vessel which was anchored out at sea. See Telephone Interview with Kenneth Hatcher, Immigration Attorney, Wilmington, North Carolina (July 5, 1990); see also Sannon v. United States, 427 F. Supp 1270, 1273 (S.D. Fla. 1977) (" [I]nterviews were conducted without counsel even though INS was well aware of the availability of counsel who were ready, willing and able to be present at the interviews."), vacated without opinion, 566 F.2d 104 (5th Cir. 1978).

169 See MEDVID INCIDENT, supra note 66.

170 See Ukrainian-American Bar Ass'n v. Baker, 893 F.2d 1374, 1377 (D.C. Cir. 1990).

171 Id. at 1381. But see Jean v. Nelson, 727 F.2d 957, 983 (11th Cir. 1984) (noting that "[t]he Supreme Court has repeatedly emphasized that counsel have a first amendment right to inform individuals of their rights, at least when they do so as an exercise of political speech without expectation of remuneration"), affd on other grounds, 472 U.S. 846 (1985).

172 Ukrainian-American BarAss'n, 893 F.2d at 1381. The court further concluded that "lawyers have no special first amendment status-that is independent of the alien's right to counsel." Id. at 1382.

173 As UNHCR envoys, these attorneys must be distinguished from "religious counselors, doctors, political activists, journalists, and a host of others [who] might want to speak with a potential defector in order to offer their services or advice." Id. at 1381-82. 
for the independent exercise of their functions. ${ }^{n 174}$ Under the Convention on the Privileges and Immunities of the United Nations, ${ }^{175}$ "[e]xperts performing missions for the United Nations shall be accorded such privileges and immunities as are necessary for the independent exercise of their functions during the period of their missions." ${ }^{176}$ As experts requested by the UNHCR to assist an incoming stowaway, attorneys should be granted access to shipboard interviews because their presence is "necessary for the independent exercise of their functions."

Furthermore, as a party to the 1967 Protocol, the United States has agreed to "undertake to co-operate with the Office of the United Nations High Commissioner for Refugees . . . and . . in particular [to] facilitate [the UNHCR's] duty of supervising the application of the provision of the present Protocol."177 Significantly, the UNHCR Executive Committee, in describing basic requirements of asylum procedures, has declared that “ $[\mathrm{a}]$ pplicants should . . . be given the opportunity, of which they should be duly informed, to contact a representative of UNHCR. ${ }^{n 178}$ This is further reason for attorneys acting at the behest of the UNHCR to be permitted access to shipboard interviews.

As a party to the Charter of the United Nations, the United States has also pledged to take "action in co-operation with the Organization for the achievement of the purposes set forth in Article 55." ${ }^{179}$ These purposes include promoting "universal respect for, and observance of human rights and fundamental freedoms. ${ }^{180}$ Those attorneys contacted by the UNHCR and present at port are assisting the High Commissioner in promoting human

174 U.N. CHARTER art. 105, I 2. The United States ratified the Charter on August 8, 1945, and it entered into force on October 24, 1945. See 79th Cong., 1st Sess., 59 Stat. 1031 (1945).

175 Convention on the Privileges and Immunities of the United Nations, Feb. 13, 1946, 21 U.S.T. 1418, 1 U.N.T.S. 15.

${ }^{176}$ Id. art. VI, § 22, 21 U.S.T. at 1434, 1 U.N.T.S. at 26.

1771967 Protocol, supra note 26, art. II, para. 1, 19 U.S.T. at 6226, 606 U.N.T.S. at 270; see also G.A. Res. 428(V), Statute of the Office of the United Nations High Commissioner for Refugees, ch. I, para. 1, 1950 U.N.Y.B. 585, 585, U.N. Sales No. 1951.1.24 [hereinafter UNHCR Statute] (stating that the UNHCR shall assume the function of "seeking permanent solutions for the problem of refugees by assisting Governments").

${ }^{178}$ Determination of Refugee Status, U.N. HCR Executive Comm., 28th Sess., No. 8, $\S$ e(iv) (1977), in U.N. HCR EXEGUTIVE COMM., CONCLUSIONS ON THE INTERNATIONAL PRotection of REFugeEs 16, 17 (1988) [hereinafter Determination of Refugee Status].

179 U.N. CHARTER art. 56.

${ }^{180}$ Id. art. 55(c). 
rights; the United States has an obligation to allow the attorneys to attend screening interviews aboard vessels.

The UNHCR tries to distance itself from the asylum adjudication once an attorney has been secured to meet the vessel. This reaction is understandable given that the UNHCR must maintain neutrality to retain credibility and that it plays only an advisory role in U.S. asylum adjudication. In many stowaway cases, however, the INS knows of UNHCR involvement because the UNHCR contacts the INS main office in Washington to inform the INS that an attorney has been secured to represent the stowaway. ${ }^{181}$ The main office, in turn, transmits the attorney's name to the INS office at the local port of call where the stowaway is to arrive. Because of this practice, UNHCR involvement is no secret. The UNHCR rarely dedicates its scant resources to securing attorneys for asylum seekers; when it does so for stowaways, it has already moved from its distant advisory role. Given this unusual involvement, the attorneys contacted by the High Commissioner are fulfilling the UNHCR mandate and are acting as UNHCR envoys.

From the perspective of the stowaway's right to counsel, Miranda warnings are not implicated because aliens are not entitled to be advised of their rights during preliminary questioning. ${ }^{182}$ Even if Miranda warnings were read to newly arrived stowaways, it is highly doubtful they would have any effect. ${ }^{183}$ Furthermore, if counsel were willing and able to board the vessel, and the alien had waived Miranda rights, the INS would not have to permit an attorney to speak with her, unless she later asserted her right to counsel. ${ }^{184}$

181 See, e.g., Record, supra note 62, at 1 ("I spoke with Scott Merry, of the shipping agency Tricom, and told him that Ms. Peng and I would both work to represent the stowaway. I understood from Scott Merry and the UNHCR that the Service was informed of this.").

182 See supra notes $161-66$ and accompanying text.

183 Seaman Medvid "was given a standard Miranda warning" but "did not take up the offer of legal assistance." Ukrainian-American Bar Ass'n, $893 \mathrm{~F} .2 \mathrm{~d}$ at 1376. It is difficult to imagine an exhausted alien, who probably knows little about our legal system, asserting her rights to counsel in the intimidating context of a shipboard screening interview.

184 See id. at 1382 . In the criminal context, when a defendant voluntarily waives her right to counsel, the police are not obligated to inform her that an attorney has been retained on her behalf. See Moran v. Burbine, 475 U.S. 412, 425 (1986) ("[A] rule that focuses on how the police treat an attorney-conduct that has no relevance at all to the degree of compulsion experienced by the defendant during interrogation-would ignore both Miranda's mission and its only source of legitimacy."). This led the court in Ukrainian-American Bar Ass'n to hold that 
This rationale for denying aliens access to counsel is not necessarily applicable in the stowaway asylum seeker context. It is improbable that counsel would encourage a stowaway to remain silent, knowing that the burden of proof lies on the stowaway and that if the stowaway does not assert a fear of persecution she will be detained on the vessel. On the contrary, counsel's presence, with the UNHCR's backing, could have the healthy effect of encouraging a stowaway to divulge her story. ${ }^{185}$ One commentator has urged that "[i]f reasonably available, ... counsel's role should be welcomed, primarily for the way in which prehearing consultation can serve to sharpen the issues and especially to encourage reticent applicants to tell the whole story. ${ }^{186}$

Furthermore, it is likely that the denial of access to counsel during a shipboard interview violates stowaways' due process rights. ${ }^{187}$ It is fundamentally unfair to deny stowaways access to a UNHCR-designated representative during a screening interview, which is typically the only forum where the right to apply for asylum can be exercised. ${ }^{188}$ This is underscored by the fact that stowaways are a unique class of aliens with limited and unclear rights of appeal who can be excluded solely on the basis of this preliminary interview. For no other group of aliens does the preliminary interview resound with such finality.

An application of the due process balancing test in Mathews $v$. Eldridge $e^{189}$ leads to the conclusion that stowaways should be

[e]ven if Medvid had a right to counsel, the Government would not have to permit a lawyer to speak with him unless he asserted that right. . . . It would seem to follow that in the non-criminal context of an asylum interview, in which the sixth amendment does not give the interviewee a right to counsel, the Government is under no obligation to advise him that a volunteer could be engaged for him.

Ukrainian-American Bar Ass'n, 893 F.2d at 1382.

${ }^{185}$ Psychologists have observed that the "preliminary interview for the hearing may also be the beginning of healing if it is appropriately handled." Rovner, supra note 129 , at 11 . An advocate's presence could be therapeutic, softening the starkness of an encounter with INS officials.

${ }^{186}$ Martin, supra note 99 , at 1352.

187 See supra notes 82-87 and accompanying text (outlining how due process rights are implicated in cases involving aliens).

${ }^{188}$ See Glazer, supra note 158, at 1178 ("For an alien seeking asylum, ... the absence of counsel makes meaningless his right to apply for relief."). While this commentator argues that asylum seekers should have a right to appointed counsel, her reasoning is particularly applicable to a stowaway's right to access to pro bono counsel.

${ }^{189} 424$ U.S. 319,335 (1976). The Mathezws test is set forth supra notes $87-94$ and accompanying text. 
allowed to consult with an attorney during the screening stage. As previously discussed, such a policy would serve both the weighty private interest and the desire to increase adjudication accuracy.

The third prong of the Mathews test warrants discussion because the government has some interest in maintaining its current policy. Certainly, the presence of counsel could lengthen the screening interview and, therefore, increase administrative and fiscal costs to the government. ${ }^{190}$ However, although the presence of an attorney might cause the INS to devote added attention to a stowaway's case, such individualized attention is mandated by the Refugee Act of 1980. Furthermore, since counsel is serving pro bono the government would not be responsible for attorney's fees.

The presence of counsel might also detract from accuracy and efficiency if, before the screening interview, the attorney told the stowaway what information to convey to immigration officials or if the attorney prompted her client during the interview. Given the circumstances of a stowaway's arrival in the United States, however, this possibility is remote. It is unlikely that the attorney would be able to communicate with the stowaway so readily and understand the gestures of the culture so thoroughly as to gain the confidence of her overwhelmed client in the short time before the screening interview. Given the utility of counsel during shipboard screening, the weighty private interest at stake, and the limited government interest to the contrary, stowaways should be permitted to communicate with attorneys at the screening stage.

In fact, this policy can be in the INS's interest; denial of a stowaway's access to counsel can serve to lessen the agency's credibility. The attorney may have to resort to calling the press or filing a habeas petition. In the latter situation, denial of access to counsel might engender judicial skepticism of the INS's position. And there is always the possibility that if the stowaway is excluded, the situation could explode into one similar to the Medvid incident or, even more likely, a situation where a stowaway drowns after jumping ship in an act of desperation. ${ }^{191}$ Either scenario would be a huge embarrassment to the INS. Damage control would then impose a greater administrative and fiscal burden than simply

${ }^{190}$ Cf. Walters v. National Ass'n of Radiation Survivors, 473 U.S. 305, 324-26 (1985) ("The regular introduction of lawyers into the proceedings would be quite unlikely to further [the] goal [of simple and efficient proceedings].").

191 The desperate situation of the Ethiopian stowaway children in North Carolina comes to mind. See supra notes $167-68$; infra note 324 . 
allowing the stowaway access to a pro bono attorney appointed by the UNHCR. If it continues to use procedures that subject the stowaway to a shipboard screening interview, the INS, should, if only for its own credibility, accord attorneys secured by the UNHCR immediate access to the stowaway.

\section{UNHCR INVOLVEMENT IN U.S. STOWAWAY CASES}

As described above, the UNHCR contacts many of the attorneys who represent stowaways as they arrive. The UNHCR is first informed about a stowaway's impending arrival either through its branch offices in countries where the vessel previously stopped en route to the United States ${ }^{192}$ or by the ship's master or agent and/or the attorney for the shipping line. ${ }^{198}$

\section{A. Duty to Report Presence of Stowaway Aboard Vessel}

Immigration law in the United States requires the master or commanding officer of a vessel to notify the INS of the presence of a stowaway after such presence becomes known to the crew. ${ }^{194}$ The law should also require that shipping lines notify the UNHCR of any stowaway due to arrive at a U.S. port. ${ }^{195}$ Unfortunately,

192 Frequently, UNHCR personnel interview the stowaways at these foreign ports of call. This happens most often in Japanese port cities, where Chinese stowaways that boarded in Hong Kong arrive. Many of the stowaways that the author encountered during the summer of 1990 had previously been interviewed by UNHCR personnel at foreign ports.

193 The ship's master can telex or telefax the UNHCR information from aboard the vessel. That attorneys for shipping lines have notified the UNHCR testifies to the deep sympathy stowaway cases can evoke; these attorneys have told the UNHCR that they wanted to ensure the stowaway was assisted with her asylum claim. See Telephone Interviews with Shipping Line Attorneys (Summer 1990).

${ }^{194}$ See INA § 231(d), 8 U.S.C.A. § 1221(d) (West Supp. 1991) (imposing a $\$ 300$ fine for each person concerning whom an accurate manifest is not delivered by the ship master to an immigration inspector); INA § 271(a), 8 U.S.C.A. § 1321(a) (West Supp. 1991) (imposing a duty on all masters, agents of vessels, and transportation lines to prevent the landing of any alien at a U.S. port of entry unless a time and place is designated by immigration officers and imposing a $\$ 3,000$ dollar fine for any violation); INA § 273(d), 8 U.S.C.A. § 1323(d) (West Supp. 1991) (imposing a \$3,000 fine for failure to detain a stowaway until inspection and denying clearance to any vessel that fails to pay this fine); see also Mason, supra note 15, at 364-66 (explaining legal duties of vessel authorities).

${ }^{195}$ Alternatively, the INS could notify the UNHCR of a stowaway's presence once informed thereof by the shipping line. However, the INS probably would balk at methodical UNHCR involvement in stowaway cases and would perceive the pro bono attorneys contacted by the High Commissioner as "vessel chasers." It would be simpler to have the shipping lines notify the UNHCR directly. 
the new asylum regulations evince regression on this matter; they specifically eliminate mention of the UNHCR as a party to whom information about asylum applicants may be given. ${ }^{196}$ While such information can be released at the Attorney General's discretion after consultation with the Secretary of State, "it was felt that it is inappropriate to specify a non-governmental agency to which the Attorney General . . . may reveal information." 197

This specious categorization of the UNHCR as a non-governmental organization contravenes the UNHCR Statute, ${ }^{198}$ through which the General Assembly of the United Nations created the office of the High Commissioner. ${ }^{199}$ The U.N. Charter specifically authorizes the General Assembly to "establish such subsidiary organs as it deems necessary for the performance of its functions." ${ }^{200}$ The UNHCR Statute further declares that the "High Commissioner shall follow policy directives given him by the General Assembly"201 and "shall report annually to the General Assembly. "202

One commentator has concluded that

[c]learly, by derivation and intention, UNHCR does enjoy international personality. As a subsidiary organ of the General Assembly, its 'personality' (its capacity to possess international rights and duties) can be traced to the United Nations at large. Moreover, its Statute shows that the Office was intended by the General Assembly to act on the international plane. ${ }^{203}$

196 See New Reg., supra note 52, at 30,676 (analyzing 8 C.F.R. § 208.6) (“Applications shall not be disclosed without the written consent of the individual, unless under the exceptions stated in this section. . . . Specific mention of the United Nations High Commission for Refugees ("UNHCR") [as an exception] is eliminated in this section.").

${ }^{197}$ Id.

198 See UNHCR Statute, supra note 177.

$199 \mathrm{See}$ id. ch. 1, para. 1, 1950 U.N.Y.B. at 585 ("The United Nations High Commissioner for Refugees, acting under the authority of the General Assembly, shall assume the function of providing international protection, under the auspices of the United Nations, to refugees . . . ."); see also UNHCR HANDBOOK, supra note 59, I 14 ("Pursuant to a decision of the General Assembly, the [UNHCR] was established as of 1 January 1951.").

200 U.N. CHARTER art. 22.

201 UNHCR Statute, supra note 177, ch. I, para. 3, 1950 U.N.Y.B. at 586.

202 Id. ch. II, para. 11, 1950 U.N.Y.B. at 587.

203 GUY S. GOODWIN-GILL, THE REFUGEE IN INTERNATIONAL LAW 133 (1983) (footnote omitted). Goodwin-Gill adds that the UNHCR's "standing in regard to protection has been further reinforced by successive General Assembly resolutions urging all states to support the High Commissioner's activities, for example, by granting asylum, observing the principle of non-refoulement and acceding to the 
The UNHCR is therefore an intergovernmental, not a nongovernmental, organization. Under international law, “ $[t]$ he duty not to return refugees to persecution or to a situation of danger to life or limb is owed to the international community of states, as represented by the UNHCR." 204 The new rule's treatment of the UNHCR as a non-governmental organization contradicts the organization's status under international law.

Because the UNHCR represents the international community of states, it would be entirely appropriate to require vessels bound for the United States to notify the UNHCR of a stowaway's presence. Commentators have urged that it is "incumbent ... to make good our intention to comply with international standards by conforming the administration of our refugee law with the advice of UNHCR." 205 Despite its expertise and impartiality, the UNHCR has only been asked to assist the INS on an ad hoc basis, most notably in reviewing all Haitian asylum cases in the late 1970 s. $^{206}$ UNHCR access sharply declined during the 1980s when the Reagan Administration balked at UNHCR involvement in asylum procedures; one official declared that these determinations are "a fundamental attribute to sovereignty. ${ }^{n 207}$ Despite this trend, the INS should "welcome UNHCR participation" because it "could improve its own credibility as a fair and unbiased agency" by cooperating with the High Commissioner. ${ }^{208}$ Again, as in the access to counsel situation, notification of the UNHCR is of paramount importance if the INS continues to deny stowaways automatic disembarkation. If INS procedures were amended to

relevant international treaties." $I d$.

204 Id. at 122.

205 Deborah E. Anker \& Michael H. Posner, The Forty Year Crisis: A Legislative History of the Refugee Act of 1980, 19 SAN DIEGo L. REv. 9, 78 (1981); see also Note, supra note 85, at 928 ("[P] erhaps we can no longer afford to leave the UNHCR out of our search for solutions to an international problem.").

206 See Anker \& Posner, supra note 205, at 77; Martin, supra note 99, at 1319.

${ }^{207}$ Martin, supra note 99, at 1320 n.192 (quoting W. Scott Burke, Compassion Versus Self-Interest: Who Should Be Given Asylum in the United States?, 8 FLETCHER FORUM 311, 325 (1984)).

${ }^{208}$ Note, supra note 85 , at 929 . Several other countries permit UNHCR representatives to participate directly in asylum proceedings, among them Australia, Belgium, Canada, France, Germany, and Italy. See Arthur C. Helton, Political Asylum Under the 1980 Refugee Act: An Unfulfilled Promise, 17 U. MiCH. J.L. REF. 243, 263-64 (1984) (detailing the involvement of the UNHCR in the asylum processes of numerous countries); see also ALEINIKOFF \& MARTIN, supra note 42, at 708 ("The agency's independence could be further demonstrated by following Germany's example of permitting the UNHCR to have a permanent observer at the agency."). 
allow all stowaways to disembark so that they could pursue their claims ashore, the UNHCR would not have to be as involved as it currently is in stowaway cases.

Because the United States is obligated to facilitate the UNHCR's duty of supervision ${ }^{209}$ and asylum seekers have the right to contact the UNHCR, ${ }^{210}$ vessels bound for U.S. ports should be required to contact the UNHCR about a stowaway's presence. Otherwise the High Commissioner has no way of knowing of a stowaway asylum seeker's impending arrival in the United States. This notification should not be left to the Attorney General's discretion as it currently is under 8 C.F.R. $\$ 208.6,{ }^{211}$ for the Executive Branch has generally been hesitant to involve the UNHCR in its operations. This skepticism is only magnified in the realm of stowaways, a class of aliens traditionally considered highly undesirable.

While the INS probably would oppose the notification requirement by asserting that it does not want UNHCR-appointed attorneys chasing vessels at port, this requirement should be implemented in light of the tenuous rights presently accorded stowaways. If the UNHCR is not involved or an attorney is unable to meet the vessel, a stowaway may be deported after an inadequate screening interview, or worse, she may jump overboard in desperation.

A further reason why the notification requirement should be imposed is that, while most shipmasters and crews befriend stowaways and go out of their way to assist them with their claims, ${ }^{212}$ there have been many incidents where stowaways have

209 See 1967 Protocol, supra note 26, art. II, para. 1, 19 U.S.T. at 6226.

210 See Determination of Refugee Status, supra note 178, at 17 ("Applicants should . . . be given the opportunity, of which they should be duly informed, to contact a representative of UNHCR.").

211 See 8 C.F.R. § 208.6 (1991).

212 See, e.g., Rebekah Denn, Chinese Stowaways Hope for New Life, SEATTLE TIMES, July 27, 1991, at A11 (describing incident in which shipping company paid over $\$ 18,000$ in custody costs for two stowaways and declared that it would attempt to do the most humanitarian thing possible, to ensure that they got a fair chance at asylum"); John Johnson, Vietnamese Stowaways Reach a Happy Landing, L.A. TIMEs, Dec. 24,1989 , at B4 (relating incident in which a Greek captain became "almost a father" to four stowaways who spent four months on his vessel while they were denied asylum in Singapore, India, Thailand, South Korea, and Japan); $c f$. Ken Ross, INS Grants Refuge to Vietnamese Stowaway, UPI, Oct. 31, 1989, available in LEXIS, Nexis Library, UPI File (recounting incident in which a Vietnamese stowaway lashed himself just above an oil tanker's propeller prompting the captain of the vessel to declare: "I am not happy with any stowaway on board but ... this kind of man, who would make this decision, is a man I can only respect"); Young Stowaways Ask Asylum From Ethiopia, 
been thrown overboard, tortured, and/or mistreated. ${ }^{213}$ The United States has a duty to assist the UNHCR in monitoring the safety of such stowaways. ${ }^{214}$

\section{B. UNHCR Release of Documents to Attomeys}

Attorneys working with stowaways have expressed frustration with the UNHCR because it requires a release to be signed by the stowaway before any documents about the case can be released to the attorney. These documents may include telexes of interviews conducted with the stowaway by UNHCR personnel at other ports of call as well documents found on the stowaway and faxed to the UNHCR by the ship's master or agent, or obtained by UNHCR personnel at other ports of call. Obviously, the stowaway's signed release can only be secured once the attorney meets with the stowaway. Thus, before the attorney can fax the release to the

supra note 44, at B2 (relating incident in which a nautical engineer mobilized refugee organizations to assist the stowaway children because he was distressed by their plight and by the treatment they had received from other crewmembers).

${ }^{213}$ See, e.g., Captain Gets 10 Years in Stowaways Trial, J. CoM., Sept. 16, 1985, at 24B (noting conviction of Greek freighter captain who "dump[ed] 11 African stowaways into shark-infested waters;" he testified that he thought they would survive because "in [his] experience sharks don't eat blacks"); Colombia Told Two Stowaways Were Thrown Overboard, REUTER LIBRARY REPORT, Dec. 8, 1990, available in LEXIS, Nexis Library (relating incident in which crewmember of Panamanian-flagged vessel bound for United States informed authorities that "two Colombians were tortured and then thrown into the sea near Cuba last November 26 after being discovered aboard the ship"); Five Illegal Haitians Found Caged, Shackled on Freighter, REUTERS, July 11, 1991, available in LEXIS, Nexis Library [hereinafter Caged Haitians] (detailing incident in which several Haitian stowaways were shackled to the deck with handcuffs and "[t]hree of the men were locked inside a four-foot cage on the ship"); Israeli Captain Is Suspended After Ship Put Stowaway Off, N.Y. TIMES, Nov. 19, 1984, at A15 (noting suspension of captain accused of forcing a Kenyan stowaway off his ship into a makeshift raft off the East African coast); Portugal Releases Asylum-Seeking Stowaways from Ship Container, REUTER LIBRARY REPORT, Apr. 20, 1989, available in LEXIS, Nexis Library ("The captain was reported to have locked [three stowaways] in a container. . . . They said they had food and water but suffered appalling conditions inside the box, where they spent four days. Two were taken to a Lisbon hotel while the third man was taken to [the] hospital with a hernia."); Rough Ride, INDEPENDENT, Aug. 17, 1991, available in LEXIS, Nexis Library ("One Ghanaian stowaway and three others died [in rough seas] after being set adrift at sea [in a life raft] by a Turkish vessel ... ."); Young Stowaways Ask Asylum from Ethiopia, supra note 44, at B2 (relating that two stowaway boys were "handcuffed and kept in a spare-parts room" and, at one port, were even put in leg chains).

214 See infra notes 290-94 and accompanying text (discussing the international duty to notify the UNHCR of the presence of stowaways aboard a vessel). The notification requirement should not be solely an obligation under U.S. law; other countries should require notification of the UNHCR under international law. 
UNHCR's offices it is possible that the vessel will have left port with the stowaway or an asylum record already will have been established while the attorney was operating without necessary information. While it is understandable that the UNHCR wishes to protect the stowaway's privacy, ${ }^{215}$ it is also the UNHCR's duty to protect asylum seekers from refoulement. ${ }^{216}$ If the UNHCR expects attorneys to represent stowaways pro bono, it should not complicate their task-which is difficult enough given obstacles created by U.S. immigration law.

Furthermore, documents found on the stowaway are no longer private; most likely the ship's crew, master, and agent will have read them, and the INS routinely receives the documents from the ship's master. Because the attorneys are acting at the behest of the High Commissioner, there should be no obstacle to providing them with transcripts of UNHCR interviews. These interviews can provide useful background information to an attorney before she reaches the stowaway's vessel. Moreover, there is little risk that an attorney would attempt to sabotage her client's case by leaking damaging information about the stowaway.

Before the UNHCR sends documents about the stowaway to the attorney, it could get a signed statement from the attorney stating that such documents are being released by the UNHCR, as an agent for the asylum seeker, with the understanding that their use will be governed by the Rules of Professional Responsibility. This method is preferable because all concerned parties operate on a more flexible timetable before the vessel arrives in port; after it arrives the attorney must focus on gaining access to the stowaway.

Even if the UNHCR is unwilling to disclose documents before receiving the stowaway's signed release, the UNHCR personnel dealing with the attorney before the stowaway arrives must make clear from the outset that their office has documents available and that a release will be needed to access them. This way, once the attorney is able to meet the stowaway, she can immediately have the release signed. ${ }^{217}$ Presently, the attorney is often not informed

215 See, e.g., L.A. Chung, Chinese Dissenter Who Hid 9 Months Gets U.S. Asylum, S.F. CHRON., Mar. 29, 1990, at A6 (describing a 26-year old stowaway who identified himself to the press "only as 'Mr. Zhang' to protect his family and sympathizers who helped him" during the pro-democracy movement in China).

${ }^{216}$ See UNHCR Statute, supra note 177 , ch. 1, para. 1, 1950 U.N.Y.B. at 585; UNHCR HANDBOOK, supra note 59, II 13-19.

217 The UNHCR should have available to the attorney a standard release form translated into the most common languages of stowaways, such as Mandarin. 
of the need for a release until after she has met the stowaway. By this time, the stowaway may be in detention or may still be on the vessel, making it extremely difficult for the attorney to arrange an interview time that is convenient for her, the INS, and the interpreter. ${ }^{218}$

Given these complications, the UNHCR should seriously consider releasing documents to the attorney before she goes to meet the vessel. Through this procedure, if the INS denies access to the attorney and the stowaway remains detained on the vessel, the attorney will at least have some information to include in the habeas petition. In addition, if the attorney must file a quick appeal, or if her client is already in detention, she will have additional information to submit on the client's behalf. ${ }^{219}$ This immediate release of information may also avoid direct UNHCR involvement, in the form of last-minute intervention, when the stowaway is about to be excluded. At that point, the INS is less likely to reverse a decision and a faulty record may already have been established.

In sum, shipping companies should be required by law to notify the UNHCR of stowaways. In addition, the UNHCR, when expecting attorneys to provide pro bono assistance to stowaway asylum seekers, should provide those attorneys with all available

${ }^{218}$ See, e.g., Record, supra note 62, at 4 ("Xiao has been in detention, and therefore unable to assist us easily. Every time I need to meet with him, I depend on an interpreter who is volunteering his or her time, and it is difficult for us to coordinate our schedules.").

219 The experience of one attorney is particularly illustrative:

[O]n the morning of August 6,1990 I telephoned Ms. Zey to say that I needed more time to obtain documents which would support Xiao's claim, and could not adequately rebut the intent to deny at the meeting scheduled for that day. Ms. Zey [the asylum officer] responded that the meeting would take place whether or not I was present. In order to protect my client's interests $I$ attended the meeting. ... I had no additional documents to submit.

Id. at 3. If the UNHCR does not release the documents in its possession and still expects the attorney to represent the stowaway by filing a habeas petition or an appeal, it may be putting the attorney in a precarious position as she may be subject to Rule 11 sanctions. See FED. R. CIV. P. 11 ("The signature of an attorney ... constitutes a certificate by the signer that the signer has read the pleading, motion, or other paper; that to the best of the signer's knowledge, information, and belief formed after reasonable inquiry it is well grounded in fact and is warranted by existing law ...."). If the attorney cannot speak to the stowaway and does not receive any documents from the UNHCR, she will have little evidence to substantiate her petition. 
relevant documents because these documents are critical for carrying out the UNHCR mandate of protecting refugees.

\section{The Right to Petition for Review}

The new rules require that those stowaways who are disembarked after making their fear of persecution known to an immigration inspector or other official must be granted ten days to file for relief with the district director. ${ }^{220}$ The district director is to forward these applications immediately to an asylum officer. A decision denying asylum to a stowaway "may be appealed directly to the Board of Immigration Appeals" within ten days of the asylum officer's decision. ${ }^{221}$

Unlike other asylum applicants who have the right to appeal to an immigration judge under INA $\S 235(b)$, stowaway asylum seekers disembarked under the new rules are denied this intermediate stage of appeal. ${ }^{222}$ A disembarked stowaway is, of course, better off than one who never even makes it off the vessel. But the denial of the right to appeal to an immigration judge and, thus, the denial of the right to an exclusion hearing, translates into unequal treatment of asylum seekers.

Aside from the initial asylum determination conducted by an asylum officer, ${ }^{223}$ the quasi-judicial hearing before the immigration judge is the only stage at which a live record is created. ${ }^{224}$

220 See 8 C.F.R. § 253.1(f)(2) (1991).

221 Id. $\$ 253.1(\mathrm{f})(4)$.

222 See supra notes 13-18 and accompanying text (describing this right of appeal); supra notes 34-36 (explaining the three levels of review generally available to asylum applicants); see also Asylum Application Mail-in Program to Asylum Offices Issuances of Charging Documents in Exclusion and Deportation Proceedings by Supervisory Asylum Officers, 56 Fed. Reg. 50810, 50810 (1991) [hereinafter 1991 Asylum Reg.] ("If an asylum officer denies the asylum claim, the alien may in most cases renew the claim before an immigration judge after the issuance of deportation or exclusion proceedings."). Notably, under the Haitian interdiction program, aliens brought to the United States and found ineligible for asylum after an initial interview can pursue their claims de novo before an immigration judge. See Procedural Changes, supra note 148 , at 805 .

${ }^{223}$ See 8 C.F.R. $\$ 208.9$ (a) (1991).

224 See Pfeiffer, supra note 95 , at 143 . Commentators have raised the concern that "two rounds of de novo consideration" delay final determinations in a system where "[s]peed is a concern, a vital concern ... . . Without speedy denials, the system will either attract large numbers of marginal claimants or else force resort to other costly and troublesome deterrents which indiscriminately burden genuine refugees." Martin, supra note 99, at 1324. Furthermore, two proceedings may be unnecessary given the current involvement of specially trained asylum officers at the initial interview stage. See Telephone Interview with David Martin, Henry L. \& Grace 
During an exclusion hearing, an asylum seeker must be "examined under oath on his application and may present evidence and witnesses on his own behalf." 225 The alien must also be afforded a reasonable opportunity to "examine and object to evidence against him, and to cross-examine witnesses presented by the Government."226 The BIA, on the other hand, "never hears live testimony from the applicant himself." ${ }^{227}$ Thus, the immigration judge's credibility findings and the record created through the testimony are critical to a comprehensive and accurate review by the BIA.

Ironically, those stowaways who manage to get off their vessels, either through a habeas petition or by swimming ashore, and who would initially be in a worse position because they were forced to remain on their vessel after an inability to articulate a fear of persecution to an immigration inspector, would be accorded greater rights of appeal. Those who swim ashore would be automatically put into deportation rather than exclusion proceedings ${ }^{228}$ and would then have the right to appeal to the BIA. ${ }^{229}$ Stowaways who depart their ships through habeas petitions would have the right to appeal their asylum decision to an immigration judge, at least in jurisdictions that accorded that right to stowaways prior to the promulgation of the new rules. ${ }^{230}$

Doherty Professor of Law, University of Virginia (Sept. 23, 1991) (telephone interview notes on file with author). While such procedures remain in place, however, they should be applied consistently to all asylum seekers.

2258 C.F.R. § 236.3(c)(3) (1991).

${ }^{226} I d . \$ 236.2(a)$.

227 Pfeiffer, supra note 95, at 142. While Pfeiffer's essay deals with the BIA's review of immigration judge findings, it is equally applicable to the BIA's direct review of credibility determinations made at the district director level. In the analogous context of labor dispute adjudication, one court concluded that "[o]ne must attribute significant weight to an ALJ's findings based on demeanor because neither the [regulatory] Board nor the reviewing court has the opportunity similarly to observe the testifying witnesses." Kopack v. NLRB, 668 F.2d 946, 953 (7th Cir. 1982).

${ }^{228}$ See In re A-, 9 I. \& N. Dec. 356, 361 (B.I.A. 1961) (“[W]here an alien has effected an entry into the United States . . . he is properly the subject of expulsion proceedings."). Expulsion proceedings are synonymous with deportation proceedings and must be distinguished from exclusion proceedings. See supra note 7. Aliens in deportation proceedings have greater rights than those in exclusion proceedings. Compare INA \$ 242, 8 U.S.C. $\$ 1252$ (1988) (describing deportation proceedings) with INA $\S 236,8$ U.S.C. $\S 1226$ (1988) (describing exclusion proceedings).

229 See 8 C.F.R. § 242.2(d) (1991).

${ }^{230}$ These jurisdictions include the Second Circuit, see Yiu Sing Chun v. Sava, 708 F.2d 869 (2d Cir. 1983), and those courts that endorsed the Yiu Sing Chun holding, see Guo-Jun Cheng v. Ilchert, 698 F. Supp. 825 (N.D. Cal. 1988); Fang-Sui Yau v. Gustafson, 623 F. Supp. 1515 (C.D. Cal. 1985); see also supra notes 40-44 and 
This disparate treatment goes directly against the mandate of the Refugee Act of 1980, which instructs the Attorney General to "establish a procedure for an alien ... at a land border or port of entry, irrespective of such alien's status, to apply for asylum . . . ."231 Not only does the new rule's limited appeal process distinguish stowaway asylum seekers from all other asylum applicants, but it also creates a sub-class of stowaway asylum seekers who are denied the interim appeal stage-other stowaways may be entitled to the appeal by staying outside of the new rules.

Thus, the new rule, promulgated to help ensure that stowaway rights conform with U.S. obligations under the Refugee Act of $1980,{ }^{232}$ actually denies to those stowaways who are able to articulate a fear of persecution and are disembarked under the new rules, an important right of appeal they previously held in several jurisdictions. ${ }^{233}$ Therefore, to comply with the Refugee Act's mandate of equal treatment for all asylum applicants, the rules should be amended to give all stowaway asylum seekers the right to an exclusion hearing before an immigration judge. Given the risk of faulty asylum determinations, asylum seekers should be accorded "effective procedural rights . . . including the right to a comprehensive review of asylum-decisions; any curtailment of such rights potentially diminishes the chances that asylum seekers can correct cross-cultural misunderstandings which have already occurred."234

accompanying text (discussing whether courts and the BIA have granted stowaways the right to appeal to an immigration judge). The California district court decisions are significant in that many stowaways arrive at the California ports of Oakland and Long Beach. The law in these jurisdictions presumably remains unchanged by the new rules, since the rules only apply to stowaways who disembark after they assert a fear of persecution to an immigration inspector or other official aboard the vessel.

231 INA § 208(a), 8 U.S.C. \$ 1158(a) (1988) (emphasis added). Moreover, in the House Conference Report on the Refugee Act, the House and Senate Committee of Conference declared that ${ }^{\text {}}[\mathrm{t}] \mathrm{h}$ e Conferees direct the Attorney General to establish a new uniform asylum procedure under the provisions of this legislation." H.R. CoNF. REP. No. 781, 96th Cong., 2d Sess. 20 (1980), reprinted in 1980 U.S.C.C.A.N. 141, 161. 232 See New Reg., supra note 52, at 30,679.

233 Admittedly, this rule was a welcome change in that it provided enhanced procedures for some stowaway asylum seekers.

${ }^{234}$ Kälin, supra note 101, at 239. 


\section{IMPLEMENTATION AND IMPACT OF SUGGESTED SOLUTIONS}

Given the problems of securing interpreters for shipboard interviews, the high likelihood of bias and rash credibility judgments on the part of immigration inspectors or other officials untrained in asylum adjudication, and the obstacles of asylum seeker reticence, all stowaways should be immediately disembarked upon arrival. ${ }^{235}$

235 Several stowaway cases under the new rule attest to the necessity of immediate disembarkation of all stowaways. When five Haitian stowaways arrived on a freighter at the port of Miami, two "jumped into the ocean about a mile from Miami Beach" and were returned to the ship by the INS. Treatment Protested, NewSDAY, July 12, 1991, News Section, at 16. After the stowaways were returned to the vessel, " [t]he captain said he was ordered by immigration officials to take the men back to Haiti and was told he faced fines of up to $\$ 15,000$ if they escaped so he put them in chains and caged some of them." Appeals Court Temporarily Stays Deportation of Four Haitians, UPI, July 25, 1991, available in LEXIS, Nexis Library; see also Caged Haitians, supra note 213 (statement of Duke Austin, INS spokesman) ("The crew said it was too hot to hold the Haitians below deck and had no other way to maintain custody of the men .... They were subject to fines if the men escaped."). Only after the happenstance "sight[ing] of the Haitians chained and caged on the ship triggered protests by Haitian exiles and brought the Haitian Refugee Center to the aid of the men" did the INS finally permit the stowaways ashore to assert their asylum claims. Appeals Court Temporarily Stays Deportation of Four Haitians, supra.

Without mandatory disembarkation, the fate of stowaways largely is determined by whether concerned individuals or agencies can intervene to prevent a stowaway's automatic exclusion and/or mistreatment. A remarkable example is the exemplary treatment of two Chinese stowaways who arrived in Seattle on June 30, 1991. In marked contrast to the debacle of the five Haitian stowaways who arrived several days later in Miami, these two stowaways were disembarked immediately, housed in a motel by the shipping agent, and later released on bond. See Chinese Freed, supra note 62; Chinese Stowaways Reportedly to Seek Political Asylum in U.S., AGENCE FRANCE PRESSE, July 16, 1991, available in LEXIS, Nexis Library. This hospitable treatment was not surprising given that "the brother of one of the [Chinese stowaways] had contacted a U.S. news agency in Hong Kong to say the women were on their way to the United States." Id. Furthermore, an attorney from Seattle's Federation for a Democratic China and a college instructor-interpreter, who met the vessel as it arrived in port, said they too had been contacted by the brother. See Chinese ProDemocracy Leaders Ask U.S. Asylum, UPI, July 15, 1991, available in LEXIS, Nexis Library.

The outcome of Xiao Guangming's case is yet another example of how critical outside assistance remains under the current rule. Through persistent advocacy, his attorney finally convinced the BIA that "the procedure before was so flawed that the fairest thing is to begin anew." Stowaway Gets Hearing, supra note 62. As a result, Xiao Guangming "was freed just 16 days after his first [asylum] hearing." Chinese Refugee Is Finally Granted Political Asylum Here-INS Hearing Clears Protester, SEATTLE TIMES, July 26, 1991, at D4. Had the UNHCR not secured counsel on his behalf, he would not have been granted this critical rehearing.

Under the new rule, stowaways without outside aid will continue to be forced to jump overboard. See, e.g., One Stowaway Drowns, Two Missing, UPI, May 28, 1991, available in LEXIS, Nexis Library ("Four stowaways sought freedom by jumping from the deck of a Panamanian freighter into the Houston Ship Channel ... but one of 
An alternative procedure for improved accuracy in asylum determinations would be shipboard screening interviews with interpreters, specially trained asylum officers, and any available attorneys present. The presence of these individuals is essential to any meaningful shipboard screening of potential asylum seekers.

The latter procedure would, however, be neither the most efficient nor accurate procedure and, consequently, would be difficult to implement. For example, locating INS interpreters who can work around a vessel's tight schedule can be a logistical nightmare. ${ }^{236}$ In addition, although the local supervisory asylum officer or her staff could meet the vessel and conduct an initial screening, sending the officer to meet one individual would be inefficient-these trips would interfere with the officer's responsibilities at her office. ${ }^{237}$ Notably, a similar system was in place until

the men drowned, one was rescued and two were missing."). One UNHCR official recounted a similar incident where an Albanian stowaway, whose vessel arrived in Newark, New Jersey during February 1991, was denied disembarkation even though he had asserted a fear of persecution to the screening officer. In an act of desperation, and with the assistance of a sympathetic captain, the stowaway asylum seeker managed to escape from the vessel and swim ashore. This incident is an eerie echo of the fate of other stowaways in Newark. See Truck Kills Stowaway from Ship, N.Y. TIMEs, Jan. 29, 1987, at B4 ("Nine stowaways on a cargo vessel from Ecuador fled the ship yesterday in Port Newark, and minutes later a truck hit two, fatally injuring one and seriously hurting another ....").

236 See supra note 67 and accompanying text.

237 The specially trained supervisory asylum officers, whose positions were created under the July 1990 rule, see supra text accompanying note 56, have begun to staff the seven new asylum adjudication sites, which opened on April 1, 1991. See INS Asylum Supervisors Named, 67 INTERPRETER RELEASES 1450, 1450 (1990). These offices are expected to become "the major sites for asylum adjudications under the new regulations. In addition, asylum officers from those sites will periodically 'circuit ride' to locations more than ...900 miles away." Id.; see also INS Opens Asylum Offices Amid Large Backlogs, Charges of Inadequate Funding, 68 INTERPRETER RELEASES 401, 403 (1991). It would often be difficult for these asylum officers to arrive on short notice from their offices to interview a stowaway at the harbor.

Significantly, a new INS interim rule, which went into effect on October 9, 1991, (with provision for post-promulgation public comments that were due November 8 , 1991), explains that "[j] urisdictions of [the asylum offices] have been developed to make effective use of full-time asylum officers ...." 1991 Asylum Reg., supra note 222 , at 50810 . Under this interim rule, asylum officers will periodically visit "ports of entry in order to interview asylum applicants." Id. The rule mandates that asylum interviews at ports of entry "be conducted after the applicant has had time to properly prepare his/her case." Id. As such, the INS concedes that accurate asylum adjudication hinges on affording asylum seekers sufficient time to prepare their case. Stowaway asylum seekers who undergo screening interviews are denied this critical time for preparation.

Additionally, under the July 1990 rule, if a stowaway is disembarked after making a fear of persecution known, the district director must "immediately forward any such 
the 1951 Immigration and Nationality Act eliminated it precisely because it was deemed a nuisance for officials to board the incoming vessels. ${ }^{238}$

While such shipboard hearings might alleviate the bias and interpreter problems, they would still be problematic because the asylum officer would be interviewing an exhausted stowaway who may have been on the vessel for weeks, if not months. Moreover, this screening would be subject to time constraints imposed by the vessel's departure schedule. The pressures that led to the fiasco in the Medvid case could easily surface in such a situation. ${ }^{239}$

Since these problems would exist under any shipboard interview process, the UNHCR would probably continue to find it necessary to locate pro bono counsel willing to meet the vessels. But under the current procedures (or any proposed reforms) pro bono attorneys alone cannot be relied on to monitor asylum determinations because they would soon be overwhelmed. ${ }^{240}$ The procedures must ensure "a full and fair opportunity to present an asylum claim [to all applicants], even if the individual is unrepresented." ${ }^{241}$ This opportunity can be realized only if the proceedings are conducted after the stowaway has been disembarked. Stowaways

application to an Asylum Officer with jurisdiction over his district." 8 C.F.R. $\S 253.1(f)(2)$ (1991). Given that the Department of Justice has recognized the importance of specially trained officers in asylum adjudication and that stowaway asylum seekers are effectively denied access to such officers because it is difficult for them to meet the vessels, stowaways should be let off their vessels so they can have an opportunity to apply for relief with the district director.

238 See S. REP. No. 1515, supra note 10, at 366-67 (emphasis added). In New York, the INS had boards of special inquiry (immigration judges) hold "hearings aboard vessels upon which the stowaways arrive[d]." Id. at 366. The Chief of the Entry and Departure Section of the INS's New York office testified that "the system of holding hearings on board incoming vessels had caused the office much concern and had been a nuisance." Id. at 367 .

${ }^{239}$ See MEDVID INCIDENT, supra note 66.

240 See Martin, supra note 99, at 1328 (noting that "the limited numbers of pro bono attorneys are easily swamped" when asylum claims increase numerically); Martin, supra note 46, at 220 ("[V]olunteer help cannot always be counted on, especially if a sudden rise in the number of asylum seekers overwhelms recruitment efforts."); Black, supra note 158 , at 299 , n.72 ("It seems doubtful that volunteer counsel could consistently handle the case-load."). Any viable proposals for changes in asylum determination procedures must "enable speedy but fair decisions in a heavily burdened system, without being entirely dependent upon the availability of pro bono efforts from the private bar." Martin, supra note 99, at 1352.

241 Martin, supra note 99, at 1329; see also Martin, supra note 46, at 221 (noting that solutions for improved asylum procedures "must rest on an adjudication system that can operate fairly even if the applicant appears without counsel"). 
then would not be such a priority protection concern and attorneys would not have to be secured. ${ }^{242}$

If the Justice Department does not amend the current procedures governing the treatment of stowaways and it is not feasible to require an asylum officer to meet each stowaway aboard the vessel, then, at a bare minimum, the INS must grant the stowaway access to an INS interpreter during the shipboard screening interview. In addition, if the UNHCR has secured an attorney for the stowaway, that attorney must be granted access to her client aboard the vessel at the same time immigration officials gain access. Lastly, carriers should be required to give the UNHCR notice of the presence of a stowaway aboard. These procedures would be a step in the right direction even if they do not fully satisfy U.S. duties under the 1967 Protocol and the Refugee Act of 1980.

Under the new rules, stowaway asylum seekers which have been disembarked "may be detained by the Service," 243 or "paroled

242 Stowaways could then be treated like other asylum seekers. One useful sideeffect of automatic disembarkation of stowaways would be that the UNHCR could reallocate some of the scarce resources it currently expends on locating pro bono counsel for stowaways. The UNHCR's intervention in stowaway asylum seeker cases is uncommon-the High Commissioner usually will only send asylum seekers lists of local attorneys and non-governmental organizations to contact. The only capacity in which the UNHCR typically assists asylum seekers directly is by writing advisory opinions in particularly compelling cases, and then only if the request is made by an attorney and the applicant is seeking withholding of deportation in a hearing before an immigration judge under INA $\$ 243(h)$. Due to limited resources, the UNHCR does not intervene when the case is still before the asylum officer. Aside from these roles, the UNHCR Legal Counsellor's office devotes significant time to drafting UNHCR amicus briefs for pivotal refugee law cases and to lobbying for systemic changes in immigration policy, both in the domestic and international arenas.

2438 C.F.R. § 253.1(f)(3) (1991). Under 8 C.F.R. § 235.3(d), the INS must assume custody of any alien subject to detention. This change from "carrier responsibility to INS responsibility for the custody and detention of excludable aliens" was effected in Final Rule, 54 Fed. Reg. 100 (1989) (codified at 8 C.F.R. $\$ 235.3(d)$ ). INS Publishes Final Rule on Custody and Detention of Excludable Aliens, 66 INTERPRETER RELEASEs 68, 68 (1989).

This rule was triggered by egregious cases such as Medina v. O'Neill, 838 F.2d 800 (5th Cir. 1988) and Lynch v. Cannatella, 810 F.2d 1363 (5th Cir. 1987). In Medina, the court found that the INS had no duty to inspect and designate an appropriate detention facility for stowaways. One of the guards at the private facility in which ten stowaways were placed 'used his shock gun as a 'prod,' which accidentally discharged, killing [one stowaway] and wounding [another]." Medina, 838 F.2d at 801 . In Lynch, 16 stowaways alleged that they "were shackled and forced to perform labor on behalf of the Harbor Police . . . under threat that refusal to work would result in withholding of food." Lynch, $810 \mathrm{F.2d}$ at 1367. The stowaways described that 
into the custody of the ship's agent or otherwise paroled. ${ }^{244}$ Last year, the INS instituted a pilot program to parole detained asylum seekers to see "whether it makes sense to release asylum seekers who arrive without valid travel documents." ${ }^{245}$ Two hundred asylum seekers (including some stowaways) have been released in Miami, San Francisco, Los Angeles, and New York City under this new program. ${ }^{246}$ The INS should continue utilizing this pro-

[t]hey were required to take showers in unheated water and, when some refused because the cold water was making them ill, were hosed down with a fire hose that slammed them against the iron walls of their cells and left their clothes, blankets, and cell so wet that they could not go to sleep.

Id. On this score, the Fifth Circuit held that because " $[\mathrm{m}]$ ost of the stowaways who were sprayed allege[d] no serious injuries as a result of the incident" their allegations did not "form a sufficient basis for recovery." Id. at 1376.

Additionally, the Harbor Police allegedly had "drugged their coffee" and then "locked them in a steel shipping container," which had been "lashed to the deck" because the barge "had no facilities for human occupancy." Id. at 1367. The stowaways maintained that "the container was in danger of being swept off the barge by heavy surf." Id. at 1367-68. Responding to these allegations, the Fifth Circuit declared that "the stowaways possessed no due process right to remain free of incarceration" and that "[e]ven the steel container provided much more humane accommodations than the bare steel barges on which they originally hid." Id. at 1376. For further discussion of this case, see infra note 324.

2448 C.F.R. $\$ 253.1(f)(3)$ (1991). Parole is a status under which an alien is permitted to come into the United States but is not officially cleared for entry. See INA $\$ 212(d)(5)(A), 8$ U.S.C. $\$ 1182(d)(5)(A)(1988)$ (indicating that "parole of such alien shall not be regarded as an admission of the alien"). A paroled alien remains subject to all of the grounds for exclusion. Deportation proceedings generally apply only when one has effected entry, even if such entry was illegal.

Traditionally, the INS paroled aliens who could not meet immigration requirements but whose entry was in the public interest. These included refugees prior to the establishment of a set procedure for their admission under the Refugee Act of 1980. Parole is still used in cases involving sick aliens or aliens who do not have time to get a visa, such as those who wish to visit a dying relative. See GIL LOESCHER \&c JOHN A. SCANLAN, CALCULATEd KINDNESS 55-56, 74, 124, 154 (1986); NoRMAN L. Zucker \& NAOMI F. Zucker, The Guarded Gate: The Reality of AMERICAN REFUGEE POLICY 31-32 (1987).

245 INS Pilot Program to Release 'Excludable' Asylum Seekers on Parole, REFUGEe REP. (U.S. Comm. for Refugees, Washington, D.C.), May 18, 1990, at 12. The asylum seekers must show the district director that "they have an attorney, employment, or other means of support" and that their claims, "if proven true, would make them eligible for refugee status." Id. "[T]hose released on parole [are] required to report each month to the local INS office and to appear at all hearings before immigration judges." Id.

246 See Laurie Goodstein, First Stop in America for Asylum Seekers: Jail; INS Considers Expanding Parole Program, WASH. POST, Sept. 15, 1991, at A3. Several of the stowaways, whose cases the author became acquainted with during the summer of 1990, were released under the parole program in San Francisco, Seattle, and Los Angeles. 
gram $^{247}$ by releasing stowaways into the custody of non-governmental organizations. ${ }^{248}$

Stowaways who are not released under the pilot program would have to be detained by the INS. This would not impose a significant financial burden on the INS because, under the INA, the vessel owners must bear these costs. ${ }^{249}$ Therefore, the INS primarily

${ }^{247}$ In a report assessing the implementation of the pilot parole program, the Lawyers Committee for Human Rights recommended that "the pilot parole project should be terminated as a demonstration project and replaced with a new general INS policy for releasing excludable aliens.” Pilot Program Releases Detained Asylum Seekers, REFuGEE REP. (U.S. Comm. for Refugees, Washington, D.C.), Feb. 28, 1991, at 10, 11 [hereinafter Pilot Program]. The expansion of the parole program would avoid the unfortunate detention situation, which has arisen since the INS reinstated this policy in 1981; aliens had not been detained since the closing of Ellis Island in 1954. As a result of the detention policy, "those who forthrightly present themselves to immigration inspectors and are not found admissible . . . can be . . . condemned to indefinite detention, while those who have the foresight to evade inspection, the mere liars and sneaks ... are able to gain entry and are in a superior legal position." Haitian Interdiction Hearing, supra note 1, at 146 (statement of Arthur C. Helton, Esq., Director, Political Asylum Project, Lawyers Committee for Human Rights).

Significantly, the new guidelines for the Haitian interdiction program state that '[a]ny aliens brought to the United States should be paroled in the 'public interest' into the care of an appropriate voluntary agency." Procedural Changes, supra note 148, at 805 . Under these procedures, the "voluntary agency would be responsible for care and maintenance and for arranging appropriate legal assistance" for the asylum seeker. Id.

${ }^{248}$ Many sympathetic non-governmental organizations have been willing to assist stowaways. These organizations have been helpful in securing pro bono counsel, as well as in finding shelter and employment for the stowaways. See generally Denn, supra note 212, at Al1 ("Members of the Chinese community have offered [the two stowaways] housing and some chances at employment . . . while they wait for the INS to review their case . . . ."); Future Still Uncertain for a Cuban Stowaway, N.Y. TIMES, Dec. 27, 1982, at B12 ("Clara Nuñez, a 20-year-old Cuban stowaway whose efforts to seek refuge in the United States became a rallying point for Miami's Hispanics [sic] community, is struggling to adjust to American life one year after her arrival."); Johnson, supra note 212, at B4 (relating that after four Vietnamese stowaways left their vessel, they "were met at the Port of Long Beach by members of the Vietnamese-American community from the city of Orange"); John McAleenan, Kids Again: 5 Stowaways Risked All to Flee War, Find Childhood, CHI. TRIB., July 13, 1988, § 5, at 1-2 (describing how a refugee resettlement expert with the Lutheran Social Services found a foster mother and immigration lawyer for five stowaway Ethiopian children). Notably, the Lawyers Committee for Human Rights has emphasized "the importance of active involvement by voluntary agencies for the success of the [pilot parole] program." See Pilot Program, supra note 247, at 11.

249 See INA \$ 237(a)(1), 8 U.S.C. \$ 1227(a)(1) (1988) ("The cost of the maintenance including detention expenses and expenses incident to detention of any [expludable] alien while he is being detained shall be borne by the owner or owners of the vessel or aircraft on which he arrived ...."). Admittedly, the INS would have to bear the cost in those cases where it is not successful in collecting the fee from the owner. 
would incur only the administrative cost of affording these detained stowaways hearings before the district director, the immigration judge, and the BIA.

Adding the intermediate level of an appeal to an immigration judge would, of course, lengthen the duration of detention; stowaway cases would no longer be adjudicated under the accelerated timetable of the new rules. ${ }^{250}$ One would hope that, as the new asylum procedures urge, "[w]here possible, expedited consideration shall be given to applications of aliens detained under 8 CFR. part 235. 251 The prospect of a stowaway asylum seeker being forced to languish in detention while awaiting a hearing is disheartening, but it is better than having her spend months, if not years, stuck on a vessel as a "refugee in orbit" 252 or being forcibly returned to persecution in the country of origin.

The suggested procedures for stowaway asylum seekers would ensure greater protection for stowaway refugees. Of course, "no procedural system, no matter how elaborate, is proof against error." 253 But while the stowaway asylum seeker ultimately bears the burden of coming forth with her history and with evidence, the system must offer an adequate and reasonable opportunity for the stowaway to make her claim. ${ }^{254}$ The ship's deck, with an immigration inspector or some other official, is simply not an adequate forum.

The United States has agreed through the 1967 Protocol, the Torture Convention, and the Refugee Act of 1980 to protect refugees from refoulement. ${ }^{255}$ Adequate protection for stowaway asylum seekers requires the right to a full hearing before a trained asylum officer, the right to all levels of appeal, the right to a

\footnotetext{
${ }^{250}$ Under the new rules, a stowaway has only ten days within which she can appeal the asylum officer's decision to the BIA. See 8 C.F.R. $\$ 253.1(f)(4)$ (1991).

2518 C.F.R. $\$ 208.5(b)$ (1991). Section 235.3(b) states, in part, that "[a]ny alien who appears to the inspecting officer to be inadmissible, and who arrives without documents . . . shall be detained." 8 C.F.R. $\$ 235.3(b)$ (1991).

252 A "refugee in orbit" is one who travels from country to country because no country is willing to grant her permanent asylum.

253 Martin, supra note 46, at 223; see also id. ("[P]erspective is needed . . . [as] asylum policy can provide, at best, only a small portion of the answer to these [human rights] abuses."); Martin, supra note 99, at 1352 ("The system cannot be designed for the chance (although it is admittedly real) that in a small percentage of the cases such delay and coaxing will unearth a meritorious case.").

254 See UNHCR HANDBOOK, supra note 59, I 196 ("[W]hile the burden of proof ... rests on the applicant, the duty to ascertain and evaluate all the relevant facts is shared between the applicant and the examiner.").

${ }^{255}$ See supra note 28 and accompanying text.
} 
qualified interpreter, and the right to UNHCR assistance. The United States cannot, in good faith, urge "Hong Kong not to deport Vietnamese asylum seekers or entreat Thailand to grant full access to UNHCR" if it ignores international law at its own borders by utilizing procedures that threaten stowaways with erroneous and avoidable refoulement. ${ }^{256}$

Stowaways were categorized as excludable aliens in reaction to the fear of an INS overburdened with stowaways arriving at U.S. shores in the first half of the twentieth century. ${ }^{257}$ The stringent treatment accorded stowaways under INA § 212(a)(18) and § 273(d) is, however, an anachronistic policy that was instituted when it was thought necessary to deter a large influx of vessel stowaways. ${ }^{258}$

256 See Arthur C. Helton, Open Letter to Ambassador Jewel S. Lafontant, United States Coordinator for Refugee Affairs, United States Department of State, Washington, D.C., 2 INT'L J. REFUGEE L. 130, 132 (1990).

257 Recall that from 1921 to $1950,13,755$ stowaways were excluded at U.S. borders. See U.S. DEP'T OF JUSTICE, supra note 5, at 111.

258 It is impossible to ascertain how many stowaways are arriving at U.S. shores. Some manage to stay in the United States through vigorous intervention by the UNHCR, non-governmental organizations, and the pro bono bar, or by swimming ashore and sneaking into the United States. Others, who die aboard their vessels or drown, are only reported in news accounts, or go unnoticed altogether. Throughout history it has been impossible to determine the number of stowaways that arrive at U.S. shores. See Jarvis, supra note 4, at 48 n.115; see also Joint Hearings, supra note 10, at 166 (transcribing statement of Alfred U. Krebs, Counsel, National Federation of American Shipping, Inc., upon being asked "how many stowaways would you say get in, or try to get in?": "Frankly, I don't have that information.").

Between May and July 1990, UNHCR secured counsel for at least 15 stowaways. This figure represents a significant increase in stowaway numbers over previous years, though it only represents stowaways about which the High Commissioner was informed. The number of stowaways will probably continue to increase. Many stowaways arriving at U.S. ports have been Chinese persons fleeing from hiding in Hong Kong. The situation in Hong Kong could deteriorate rapidly as 1997 approaches. These worsening conditions could heighten desperation and trigger stowing. See generally Activists in Hong Kong Assist 4 Chinese Dissidents to Escape, WASH. POST, June 27, 1989, at A18 (reporting that an "underground railroad" is helping student leaders and intellectuals escape China's crackdown on supporters of the prodemocracy movement); Barbara Basler, Colony's Cold Shoulder for Democracy's Goddess, N.Y. TIMES, Dec. 25, 1989, at A4 ("Hong Kong, which is to be handed back to China in 1997, is now quick to censor itself, and equally quick to criticize any word or deed that could upset or offend China."); Fox Butterfield, Beijing Protesters Said to Flee to a Now-Uneasy Hong Kong, N.Y. TIMES, June 30, 1989, at A1 (noting that the crackdown in Beijing and the flight of protesters is "spreading concern among residents that Hong Kong should avoid doing anything to offend China"); Stephen Schwartz, Chinese Democracy Supporter in S.F., S.F. CHRON., Dec. 1, 1989, at A29 ("[T]he Beijing government is pressuring Hong Kong leaders to curb the movement that supports Chinese dissidents ....").

Unsurprisingly, countries have begun to encounter stowaways from the world's most recent trouble spots. See, e.g., Iraqi Stowaways Seek Asylum in Argentina, REUTERS, 
Presently, control over U.S. land borders and airports is the greatest concern for the INS. ${ }^{259}$ Although it is true that "stowing away is as old as shipping, ... in our modern times it is almost as old as flying. "260 An uncontrollable influx of vessel stowaways is highly unlikely.

Admittedly, expanded procedures for stowaways could encourage marginal asylum applicants to stow away in an effort to bypass overseas screening procedures. Such an increase in the number of stowaways arriving by vessel could in turn trigger compassion fatigue and a sense of loss of control over our borders. ${ }^{261}$ Public

July 11, 1991, available in LEXIS, Nexis Library (relating incident involving Kurdish stowaways); Liberian Stowaway Escapes Ship, INDEPENDENT, June 1, 1991, available in LEXIS, Nexis Library (relating incident in which one Liberian stowaway escaped custody and "five more refugees from the Liberian civil war were on two other vessels waiting to dock"); Seven Kurds From Iraq Granted Asylum in South Africa, REUTERS, Feb. 10, 1991, available in LEXIS, Nexis Library ( $[$ [T] he [Kurdish] men arrived [in South Africa] as stowaways ... to escape the looming war.").

However, even if all of these stowaways were accounted for, they would not number more than several hundred per year. It is not their numbers that makes the situation of the stowaways compelling, but rather their precarious situation under U.S. immigration law.

259 The immense increase in arrivals by plane has led to the coining of the term "jet people" for this group of asylum seekers. One commentator has noted that "[t]he latest class of refugees does not travel as refugees used to do, on foot, by rail, or by boat. It travels by intercontinental jet." SMYSER, supra note 6, at 92 .

260 Joint Hearings, supra note 10, at 205 (statement of Joseph Mayper, Chairman and Counsel, Trans-Atlantic Passenger Conference). The quote begins: "Any of you who have read sea stories for generations back know that stowing away is as old as shipping ...." Id. at 205. Such a romanticized vision of stowing away is prevalent in our culture. Not only is it common in literature, see e.g., Richard Eder, A Sprawling Picaresque Novel, L.A. TIMES, Nov. 22, 1990, at E14 (reviewing LESLIE EPSTEIN, PINTO AND SoNs (1990)) (summarizing that Pinto "stows away aboard a Europe-bound ship, only to find it is headed for the California Gold Rush"), but stowing away is also portrayed rosily in movies, see, e.g., Marcia Froelke Coburn, Reunited: The Long and Bumpy Road to Love, CHI. TRIB., Jan. 3, 1991, Tempo Section, at 6 (recommending Warren Beatty's REDS (Paramount 1981), during which Louise Bryant "stows away on a freighter and treks across a vast frozen tundra" in search of her lover, John Reed); Christopher Cornell, The Marx Brothers at the Movies, CHI. TRIB., Nov. 9, 1990, Friday Section, at 56 (suggesting that the movie MONKEY BuSINESS (MCA/Universal 1931), "may be the best film for introducing a neophyte to the Marxes, with the four crazies playing stowaways aboard a luxury ocean liner chock-full of pompous characters"); Henry Sheehan, Film Review: 'Shipwrecked', BPI, Feb. 28, 1991, available in LEXIS, Nexis Library (describing the film SHIPWRECKED (Walt Disney Pictures 1991), as "intelligent family entertainment" in which a "feisty girl . . . stows away on the ship ... and finally [helps] to vanquish the buccaneers"); see also Jarvis, supra note 4, at 2627 n.6 (listing a television series and several movies depicting stowaways).

One commentator has written that "the law of the sea and coast is fascinating. Like the sea and coast themselves, it is irresistibly seductive. The figurative potential alone has a powerful pull." MILNER S. BALL, LYING DOWN TOGETHER 35 (1985). This 
fascination makes it difficult to imagine that one would be stowing away to avoid persecution or that stowing away aboard a vessel not designed for passengers could be life-threatening. The truth, however, is much harsher than the romanticized fiction. See, e.g., Anne-Marie O'Connor, Nightmare Voyage: Hellish Heat Kills Six of Eight Dominicans Smuggled Into U.S. in Ship's Cargo Hold, OTTOWA CITIZEN, July 6, 1991, available in LEXIS, Nexis Library) (describing how six of eight stowaways in a sealed freight container died after "pounding on the container and yelling, 'Let us out. We're dying"); Stowaways Set Fire in Ship, N.Y. Times, Feb. 29, 1988, at B9 ("Four Dominican stowaways who were locked in the cargo hold of a container ship set a fire early today to get the crew's attention ....")

261 If the number of stowaways grew, the Justice Department" or Congress might try to curb the influx by further increasing the penalties on carriers. This should, however, be avoided. If stowaways were granted greater rights, the period required to process their asylum applications would increase and, as a result, carrier costs would rise for the shipping companies that are responsible for the stowaway's maintenance. Thus, enhanced rights for stowaways would translate into increased costs for carriers independent of any additional penalties.

Furthermore, increased fines would not necessarily decrease the number of stowaways boarding at foreign ports. In 1950, during the hearings on the INA, Congress accepted this premise when it eliminated proposed INA § 273(e), which sought to impose a $\$ 500$ penalty against carriers for simply having a stowaway aboard. The Federation of American Shipping persuasively argued that their crews search the vessels, that gangway watchers are on constant alert, and that, where possible, shoreside gangway watchers and local police are also utilized. Furthermore, the Federation argued that the companies are

responsible for the safekeeping of the stowaway until he is turned over to proper authorities and ... must hire a guard to watch him. Even after a stowaway is turned over to the proper authorities, his maintenance and detention expenses are for the account of the company. If he requires medical attention or hospitalization the company pays for it. The company must arrange for his transportation if he is deported . ... [Moreover i]t is, and always will be, extremely difficult to prevent stowaways from boarding a vessel and to locate them after they are aboard. Unfortunate individuals ... are seeking to escape from the unhappy circumstances ... [and b]eing frequently without means, necessity has forced upon them the requirement to devise and execute ingenious schemes to board and secrete themselves on ships .... The fact that certain of these persons are able to board ... vessels is not evidence of a lack of diligence on the part of shipping companies and their agents.

Joint Hearings, supra note 10, at $171-72$ (statement of Alfred U. Krebs, Counsel, National Federation of American Shipping, Inc.); see also Jarvis, supra note 4, at 31-33 (describing the American shipping industry's opposition to increased penalties for ships with stowaways because the carriers were already taking "maximum precautions").

A similar situation exists today. One captain who had five stowaways aboard declared:

People tend to glamorize it, but this is an expensive and ongoing problem for shipping companies in ports of all the Third World countries. We lock the ship up tight while in port to minimize the hiding places. We hire local police to guard the gangplanks. Then, after we're loaded and ready to go, the standard operating procedure is to scour the ship from top to bottom. We caught three older boys earlier that night. Then later we found a 
support, however, as well as control over U.S. borders, can be maintained through "a system capable of saying 'no' to the unqualified-fairly, but firmly and expeditiously-while promptly welcoming the meritorious applicant."262 The U.S. immigration system should not compensate for the difficulties it has in removing people by summarily screening out stowaway asylum seekers. They are entitled to protection under U.S. and international law, and should not have to bear the brunt of an immigration system in need of repair.

If the United States implemented fairer and more thorough procedures for dealing with stowaway asylum seekers, it could pressure other countries to do the same. Almost all stowaways pass through foreign ports before landing in the United States; these other nations must share responsibility for such stowaways. The United States should take the lead in drafting, signing, and monitoring the implementation of an International Convention on Stowaways. Ultimately, the granting of greater rights to stowaways worldwide could lead to a decrease in the number of stowaways who arrive at U.S. shores.

\section{Duties Of Protecting Stowaway Asylum Seekers UNDER INTERNATIONAL LAW}

\section{A. The International Convention Relating to Stowaways}

The only existing treaty on stowaways-the International Convention Relating to Stowaways ${ }^{263}$ drafted in 1957-has not come into force because only nine of the ten countries required have ratified it. ${ }^{264}$ The Convention calls on masters of ships flagged in states that are parties to the agreement to "deliver the stowaway to the appropriate authority at the first port in a Contracting State at which the ship calls after the stowaway is found." ${ }^{265}$

younger boy in a barrel on deck just as we were ready to sail.

McAleenan, supra note 248, at C1, C2.

262 Martin, supra note 99 , at 1270.

${ }^{263}$ International Convention Relating to Stowaways, Oct. 10, 1957, reprinted in 8 NAGENDRA SINGH, BRTTISH SHIPPING LAWS: INTERNATIONAL CONVENTIONS OF MERCHANT SHIPPING 1354 (2d ed. 1973) [hereinafter Stowaway Convention].

264 See M.J. BOWMAN \& D.J. HARRIS, supra note 26, at 222-23. It is possible that other countries have been hesitant to ratify this Convention and thereby be labelled as the country that imposed new obligations on the nine previous parties, for the Convention then would come into force.

${ }^{265}$ Stowaway Convention, supra note 263, art. 2, para. 1, at 1355. 
This port state is to shelter the stowaway temporarily but can send her back to her home country, back to the port where she boarded the ship, back to the last port at which the vessel called before arriving at this port state, or back to the country where the vessel was flagged (in this decreasing order of preference). ${ }^{266}$ If the authorities of the port state believe the stowaway would face persecution in a particular country, that potential destination must automatically be eliminated. ${ }^{267}$ If no country is willing to accept the stowaway, the flag state has the ultimate duty to do so. ${ }^{268}$

Only Belgium, Denmark, Finland, Italy, Madagascar, Morocco, Norway, Peru, and Sweden have ratified this treaty. ${ }^{269}$ Brazil, France, Germany, Greece, India, Iran, Israel, Portugal, Spain, Switzerland, and Vatican City have signed the treaty but not ratified it. $^{270}$ By ratifying the Convention, the Scandinavian countriesDenmark, Finland, Norway, and Sweden-have arguably created a regional custom to which they are bound under international law. 271 Furthermore, Germany, Greece, and Spain have also ratified the Vienna Convention on the Law of Treaties. ${ }^{272}$ They are bound by Article 18 of the Vienna Convention which states: "A state is obliged to refrain from acts which would defeat the object and purpose of a treaty when: (a) it has signed that treaty ... subject to ratification, acceptance or approval, until it shall have made its intention clear not to become a party to the treaty. ${ }^{273}$ These countries are therefore obligated to uphold the goals of the Stowaway Convention. These include the duties of countries to refrain from sending stowaways to persecution, ${ }^{274}$ of port states

266 See id. art. 3, paras. 1-4, at 1355.

267 See id. art. 5, para. 2, at 1356 ("As regards the application of the [Convention's] provisions, "the Master and the appropriate authorities of the port of disembarkation will take into account the reasons which may be put forward by the stowaway for not being disembarked at or returned to those ports or States mentioned in this Convention."); see also text accompanying note 266.

268 See id. art. 3, para. 4, at 1355.

${ }^{269}$ See BOWMAN \& HARRIS, supra note 26, at 223.

270 See id.

271 Customary international law is evidenced by the customs and practices of states. For a practice to become customary law it must have the "general assent of civilized nations." The Paquete Habana, 175 U.S. 677, 694 (1900); see also Filartiga v. Pena-Irala, 630 F.2d 876, 881 (2d Cir. 1980) (declaring that "civilized nations have banded together to prescribe acceptable norms of international behavior"). Regional custom arises when the countries of a specific geographic area assent to the same international practice.

272 Vienna Convention on the Law of Treaties, May 23, 1969, 1155 U.N.T.S. 331. 273 Id. art. 18, 1155 U.N.T.S. at 336.

${ }^{274}$ All of the signatory and ratifying countries of the Stowaway Convention, except 
to offer temporary shelter to stowaways, and of flag states to bear ultimate responsibility for stowaways who cannot be resettled elsewhere.

Because only one country is needed for the Stowaway Convention to enter into force, the United States is in a position to create international law simply by ratifying this Convention. The United States should do so immediately so that stowaways could at least receive protection from those countries who are parties to the Convention. This would be significant because the Scandinavian countries that have ratified the Convention are maritime states with large fleets; stowaways would be protected aboard vessels flagged in these party states, and these flag states would bear ultimate responsibility for them. In conclusion, not only should the United States ratify the Stowaway Convention, but it should also help generate international consensus around the drafting of a more comprehensive and effective treaty. Such a draft could be introduced by a UNHCR Working Group, under U.N. auspices.

\section{B. The Special Obligation of Port States}

By placing the ultimate burden of accepting a stowaway on the flag state, the Stowaway Convention does not offer an ideal solution. About thirty-five percent of the world's merchant fleet is now registered under flags of convenience. ${ }^{275}$ Owners register their vessels under these flags because of "low fees and tasation, together with lower crew costs, and in some cases savings from not having to comply with international safety standards. ${ }^{276}$

Sending stowaways to flag countries would result in asylum seekers being placed in countries to which they have a remote link $\mathrm{k}^{277}$ and would put a disproportionate burden on a small

Italy, Madagascar, and Brazil, have acceded to the 1951 Convention and 1967 Protocol, without reservations. See UNHCR HANDBOOK, supra note 59, Annex IV, at 86-87. India and Vatican City have not accepted either refugee treaty. See BowMaN \& HARRIS, supra note 26, Seventh Cumulative Supp. 1990, at 121. The Stowaway Convention does not discharge states of their duties under the other refugee agreements; it specifically states that " $[t]$ he provisions of this Convention shall not in any way affect the power or obligation of a Contracting State to grant political asylum." Stowaway Convention, supra note 263, art. 5, para. 3., at 1356 (emphasis added).

${ }^{275}$ Popular flag states include Panama, Liberia, Cyprus, Somalia, and Vanuatu.

276 R.R. CHURCHILl \& A.V. LOWE, THE LAW OF THE SEA 206 (1988).

277 See Stowaway Asylum-Seekers, supra note 3, at 3 ("[A]lthough the connection between the stowaway asylum-seeker and the State of the first port of call may be remote and coincidental, that person's link with the Flag State is usually even more 
number of countries. ${ }^{278}$ A more practical solution is to have the port state of the first port where a stowaway lands after being discovered bear ultimate responsibility for the stowaway. Although a vessel is considered the floating territory of the flag state, once that vessel comes into a port, the port state can exercise full control over immigration into its territory under the 1958 Convention on the Territorial Sea and Contiguous Zone ${ }^{279}$ and the 1982 United Nations Convention on the Law of the Sea. ${ }^{280}$ The UNHCR has noted this exclusive jurisdiction of the port states over foreign vessels within their territory, ${ }^{281}$ as have commentators. ${ }^{282}$

A stowaway should immediately be disembarked at the first port of call upon the discovery of her presence. The port state can then seek to resettle her elsewhere, depending on the particular case,

remote and quite fortuitous."). The port state is much more likely to be in the geographic region of the stowaway's country of origin. Acceptance of responsibility by the port state would coincide with the UNHCR's policy of favoring local integration. It is easier for a refugee to adapt to an environment similar to her own.

${ }^{278}$ See id. This problem of disproportionate burden has arisen in the context of the debate over the Indochinese boat people. Maritime states such as Greece have argued that "the rescue ... at sea [program] should not impose flag-state responsibility; that responsibility rested with all signatories of the Convention and Protocol and the problem should be thoroughly re-examined with a view to an equitable sharing of the burden." GOODWIN-GILL, supra note 203, at 90 (quoting U.N. Doc. A/AC.96/SR.319).

279 Convention on the Territorial Sea and Contiguous Zone, Apr. 29, 1958, art. 24, para. 1(a), 15 U.S.T. 1606, 1612, 516 U.N.T.S. 205, 220 ("In a zone of the high seas contiguous to its territorial sea, the coastal State may exercise the control necessary to: (a) Prevent infringement of its . . . immigration . . . regulations within its territory or territorial sea."). The contiguous zone is defined as the zone up to twelve miles from the baseline. See id. art. 24, para. 2, 15 U.S.T. at 1612, 516 U.N.T.S. at 220.

${ }^{280}$ Sea Convention, supra note 46 . This Convention states:

Passage of a foreign ship shall be considered to be prejudicial to the peace, good order or security of the coastal State if in the territorial sea it engages in any of the following activities: . . . (g) the loading or unloading of any. . . person contrary to . . . immigration ... laws and regulations of the coastal State.

Id. pt. II, § 3, art. 19, para. 2(g), 21 I.L.M. at 1274.

281 See Stowaway Asylum-Seekers, supra note 3, at 3 ("Coastal States enjoy absolute jurisdiction over their territory .... Foreign ships in port cannot grant asylum on board .....").

282 Martin, supra note 99, at 179 (stating that aliens detained aboard ships in U.S. territorial waters "plainly come within the jurisdiction of the United States in the significant sense that this country's sovereign will ... can be applied to them immediately, uncomplicated by any direct contest with another sovereign nation."); see also GoODWIN-GILL, supra note 203, at 91 ("[I]t may be appropriate to emphasize the responsibility of the first port of call, given the inescapable but internationally relevant fact of the refugees' presence within the territory of the state."). 
after considering the stowaway's wishes ${ }^{283}$ and family connections abroad. The port state, however, should bear ultimate responsibility if the stowaway cannot be resettled. With this procedure in place, the flag state would have the duty to treat a stowaway decently while she remains on board the vessel, while the port state would have responsibility for granting asylum to a stowaway fleeing persecution.

If a port state requires a ship's master to detain a stowaway "on board and travel on to the next port of call" or leaves it to "the flag state to assume responsibility where the next port of call is unacceptable, ${ }^{284}$ it could be considered a breach of the 1951 U.N. Convention, the 1967 Protocol, and the Torture Convention. As one commentator has argued convincingly that

[i]f the flag state refuses to accept any responsibility for resettlement and if the ship's next port of call is in a country in which the stowaway asylum-seekers' life or freedom may be threatened, then the practical effect of refusal of entry is refoulement. The nominal authority of the flag state to require diversion to a safe port, which would anyway be controversial where a charter party was involved, can hardly be considered a practical alternative, or 'last opportunity', to avoid refoulement. The paramount consideration remains the refugee status of those on board; a refusal to take account of their claims, either on the specious basis that they have not 'entered' state territory or on the (disputed) ground that they are the responsibility of the flag or any other state, would not suffice to avoid liability for breach of the principle of non-refoulement. ${ }^{285}$

Because a port state's inaction could result in the stowaway being sent to persecution, any new treaty relating to stowaways should mandate that the port state bear ultimate responsibility for a stowaway. ${ }^{286}$

${ }^{283}$ See Refugees Without an Asylum Country, U.N. HCR Executive Comm., 30th Sess., No. 15, § h(iii) (1979), in U.N. HCR EXECUTTVE COMM., CONCLUSIONS ON THE INTERNATIONAL PROTECTION OF REFUGEES 31, 32 (1988) [hereinafter Conclusion No. 15] (stating that "[t]he intentions of the asylum-seeker as regards the country in which he wishes to request asylum should as far as possible be taken into account ${ }^{n}$ ).

284 GoodwIN-GILL, supra note 203 , at 85.

285 Id. at 86-87.

286 This system would avoid a worst-case scenario in which vessel captains, feeling responsible for the fate of the stowaway, try to rid themselves of the stowaway to avoid censure by their employers. A similar tragic situation has, in fact, arisen in the South China Sea, where the Thai and U.S. governments set up an anti-piracy program in 1981 that operates in conjunction with an international program run by the UNHCR. As authorities began to arrest and prosecute pirates, they also began to note a horrifying development. Although the number of attacks declined sharply, "more of the pirate attacks than ever before seemed intent, not just on robbery and 
Problems could arise, however, with making port states responsible for stowaways; many of the first port-of-call countries at which stowaways arrive are unwilling to assist them. Few of these nations are parties to the Stowaway Convention and many are not even parties to the 1951 Refugee Convention or the 1967 Protocol. Stowaways ultimately granted asylum in the United States are known to have been previously rejected by Singapore, India, Thailand, South Korea, Japan, Bahrain, Dubai, the United Arab Emirates, and Saudi Arabia. ${ }^{287}$ Most Chinese stowaways who have departed Hong Kong ports during the past two years go through Singapore, Taiwan, and/or Japan before their arrival in the United States. ${ }^{288}$ The countries through which stowaways and other asylum seekers pass are generally not very receptive toward them. ${ }^{289}$ However,

mayhem, but total massacre." Court Robinson, Pirate Attacks on Vietnamese Refugees Grow More Vicious, WORLD REFUGEE SURV. (U.S. Comm. for Refugees) 58, 58 (1989). Experts have suggested that "with the growing sophistication of investigation techniques, coupled with higher rates of arrests and convictions, pirates try to be sure to leave no witnesses." Id.

An equally grisly situation could arise if captains felt they would be penalized by their shipping companies (who would be responsible if the flag state had to accept the stowaway) for not having discovered the stowaway before leaving port. One would only hope that such action would be deterred by the humaneness of the captains or by the threat of criminal prosecution if authorities became aware of an incident. While those who commit piracy against the boat people are a wretched group, generally, captains of vessels with stowaways are civilized people who have behaved properly in the past.

287 See Johnson, supra note 212 , at B4 (noting that stowaways were denied asylum in Singapore, India, Thailand, South Korea, and Japan); U.S. Denies Stowaway Asylum, L.A. TIMES, Oct. 31, 1989, at P2 (noting that a stowaway, Tuan Van Nguyen, was denied asylum in Singapore, Bahrain, Dubai, the United Arab Emirates, and Saudi Arabia). Despite initial rejection by the U.S. State Department, Mr. Nguyen later was granted asylum by the INS, which overruled the State Department. See Vietnam Stowaway Granted Asylum, L.A. TMES, Nov. 1, 1989, at A27.

${ }^{288}$ See, e.g., Denn, supra note 212, at A11 ("The crew tried to leave the [two Chinese stowaways] at other ports in Taiwan and Japan but 'they refused to accept the ladies'....").

${ }^{289}$ See, e.g., Chinese Stowaways Indicted for Breach of Immigration Law, KYODO NEwS SERVICE, Oct. 24, 1990, available in LEXIS, Nexis Library ("Prosecutors . . . . indicted 15 Chinese stowaways on charges of violating immigration regulations."); Johnson, supra note 212, at B4 (reporting that, after being refused entry into Japan, three stowaways jumped into Japanese waters in an act of desperation and two of their bodies were later recovered); Nicholas D. Kristof, Taiwan Accused in Deaths of 25 Refugees at Sea, N.Y. TMES, Aug. 26, 1990, at 21 (reporting that 25 Chinese suffocated during forcible repatriation to China while locked in crowded cabins); Nicholas D. Kristof, Taiwan Is Ambivalent on Mainland Refugees, N.Y. TIMES, Feb. 8, 1991, at A12 (reporting that thousands of mainland Chinese have been deported from Taiwan); Molly Moore, Philippine Demands Strand Refugees on U.S. Navy Ship at Subic, WASH. Post, June 12, 1990, at A20 ("Philippine officials . . . have announced that they will 
an international consensus generated by the drafting and prospective ratification of a more effective stowaway convention could serve to modify the uninviting policies of these first port-of-call countries. This would be a welcome shift because it is more practical for port states, rather than flag states, to bear responsibility for stowaway asylum seekers arriving at their shores.

\section{The Role of the UNHCR}

Given the problems in obtaining asylum for stowaways in port states, the UNHCR should become involved immediately after a stowaway is discovered. A new stowaway convention should impose a duty on shipmasters to notify the UNHCR of a stowaway's presence, and a duty on port states to notify UNHCR authorities upon a stowaway's arrival. The UNHCR could then monitor the situation to ensure that stowaways are humanely treated aboard vessels, as required by international law. ${ }^{290}$

Notification would also allow the UNHCR to monitor asylum adjudication in the port states, and if those states refused to grant asylum to a stowaway, the UNHCR could intervene to try to find a country that would grant asylum. As the UNHCR Executive Committee noted, "[i]f necessary, UNHCR should be requested to assist in finding a durable solution." 291 The Committee has also concluded that "States should give favourable consideration to accepting, at the request of the Office of the [UNHCR], a limited number of refugees who cannot find asylum in any country. ${ }^{292}$

not allow U.S. warships-or other vessels-to leave refugees on their shores unless the country to which the ship is registered can guarantee the individuals will be resettled elsewhere within six months."); REFUGEE REP. (U.S. Comm. for Refugees, Washington, D.C.), June 22, 1990, at 5 ("The government of the Philippines has refused to allow 101 Vietnamese boat people aboard a U.S. naval supply ship in Subic Bay to disembark."); Steven R. Weisman, New Indignities for Refugees in Japan, N.Y. TMMES, Oct. 24, 1989, at A3 (noting that arrivals of Chinese and Vietnamese boat people have "rekindled the debate about how far Japan should go to fulfill its international obligations"). Interestingly, both Japan and the Philippines are parties to the 1951 Refugee Convention and 1967 Protocol. See UNHCR HANDBOOK, supra note 59, annex IV.

290 See MARTIN J. NORRIS, THE LAW OF SEAMEN $\$ \S 15,553,667$ (4th ed. 1985) (stating that a vessel owes a stowaway the duty "to afford him humane treatment while he .. . remains on board"); see also Buchanan v. Stanships Inc., 744 F.2d 1070, 1074 (5th Cir. 1984) (recognizing that stowaways are normally due humane treatment), rev'd on other grounds, 485 U.S. 265 (1988).

291 Stowaway Asylum-Seekers, supra note 3, at 6.

292 Conclusion No. 15, supra note $283, \S l$. 
While the UNHCR now intervenes on an ad hoc basis to find asylum countries for stowaways, ${ }^{293}$ it would be able to do so on a more systematic basis if shipmasters and port states were obligated to inform the High Commissioner about stowaways. A consistent program of intervention would not unduly burden the local offices of the UNHCR because they are already involved in many stowaway cases through their monitoring of stowaway arrivals and interviewing of stowaways aboard vessels in port states. ${ }^{294}$

Another concern the UNHCR could address is the fate of stowaways who are caught by ship captains prior to leaving foreign ports. If a stowaway is discovered while the vessel is still in port, she will usually be forced off and handed over to authorities who will presumably treat her as a defector. ${ }^{295}$ A new stowaway convention might impose a duty on shipmasters to contact the UNHCR, or at least a non-governmental organization, before the stowaway is forcibly removed from her vessel. Implementing this requirement would be difficult, however, because stowaways might be discovered just as the vessel is about to leave port, when the crew typically

${ }^{293}$ See Iraqi Deserter Winds Up in Brazil, UPI, Feb. 10, 1991, available in LEXIS, Nexis Library (recounting that stowaway asylum seeker in landed who Rio de Janeiro was "expected to be turned over to the Brazil office of the [UNHCR]"); Johnson, supra note 212, at B4; McAleenan, supra note 248, at 2; see also GoODWIN-GILL, supra note 203, at 85-86 (detailing UNHCR intervention in two cases involving stowaways in Australia, after Australia demanded a resettlement guarantee in one case and the UNHCR's promise to use its best efforts to effect resettlement in a third country in the other).

294 These activities are especially prevalent in Japan. See supra note 192 and accompanying text.

295 See MEDVID INCIDENT, supra note 66, at 18-22, 66-68 (speculating that after the Ukrainian seaman was forcibly returned to his vessel and later beaten by other crewmen, he was drugged before being re-released to U.S. authorities), see also McAleenan, supra note 248 , at 2 ("[W]e found a younger boy in a barrel on deck just as we were ready to sail. He was taken off and greeted rather roughly, I'm afraid. The soldiers were banging him around pretty good as they took him away."). One Ethiopian boy who remained on that vessel as a stowaway claimed that $\left.{ }^{\text {" }} \mathrm{t}\right] \mathrm{h}$ e last time the army talked with [him] was after he had been caught trying to sneak aboard a ship." The reporter noted that the boy's "legs are a patchwork of scars from being wrapped in chains for several weeks." Id. Another stowaway child who made it to the United States on that ship was forced to "'knee-walk' for a mile or more on the blistering sand ${ }^{n}$ by soldiers as punishment for trying to sneak aboard an Italian freighter in port. Id.

One young Ethiopian stowaway stated that "[p]eople who have attempted to flee Ethiopia as stowaways and are caught often disappear .... When they disappear, they are often killed." Young Stowaways Ask Asylum from Ethiopia, supra note 44, at B2. Such harsh treatment of prospective stowaways is of grave concern, given that attempting to emigrate is a crime in many countries. See HURST HANNUM, THE RIGHT TO LEAVE AND RETURN IN INTERNATIONAL LAW AND PRACTICE 51 (1987). 
works on a tight schedule and UNHCR personnel may be unavailable. In sum, the UNHCR should be notified of stowaways once they are discovered aboard vessels on the high seas so it can assist them in finding asylum countries. Where feasible, the UNHCR should also be notified of the existence of stowaways that are ejected from vessels in the ports where the stowaways boarded so that it can assist these asylum seekers as well.

\section{Heightened Duties Toward Child Stowaway Asylum Seekers}

One class of stowaways merits particular attention: stowaway children. These asylum seekers deserve special care from the international community and special consideration in any newly drafted stowaway convention. The UNHCR has repeatedly highlighted the special situation of refugee children. ${ }^{296}$ One captain's comments about the five children from Ethiopia who stowed away on his vessel demonstrate their precarious situation:

They are nice kids, but stowaways-especially kid stowaways-are a supreme pain. There's simply no place, no provisions for housing them, no really good way to take care of them. ... The paperwork, crew overtime, cables back and forth, putting attorneys to workall that has already cost the company several thousand dollars. ... You have to lock them up, you have to feed them, you have to coddle them. It's a mess. ${ }^{297}$

Nonetheless, this captain noted that "I guess I'd not like to see them sent back. There's not much family life there anymore. I think only two of them ... still have any kind of family intact. The others are essentially homeless. They have fled a pretty horrible scene." 298 The plight of these children brings to mind the Child-

${ }^{296}$ See Refugee Children, U.N. HCR Executive Comm., 38th Sess., No. 47, § c (1987), in U.N. HCR EXECUTIVE COMM., CONCLUSIONS ON THE INTERNATIONAL PROTECTION OF REFUGEES 105, 105 (1988) (reiterating "the widely-recognized principle that children must be among the first to receive protection and assistance") (emphasis omitted); Report of the Fortieth Session of the Executive Committee, U.N. HCR Executive Comm., 40th Sess., I 26, § h, U.N. Doc. A/AC.96/737 (1989) (calling upon "UNHCR to promote the best possible legal protection of unaccompanied minors").

${ }^{297}$ McAleenan, supra note 248, at 2 (quoting Bill Weiss, Captain of the grainfreighter, the Galveston Bay).

298 Id. For other accounts of child stowaway asylum seekers, see Young Stowaways Ask Asylum From Ethiopia, supra note 44, at B2 ("One hot evening this summer, two Ethiopian boys fled their homeland. By moonlight, they dived into the Red Sea, swam to a ship anchored offshore and climbed aboard."); Three Somali Stowaways Apply for Political Asylum in Tanzania, BRITISH BROADCASTING CORP., Jan. 10, 1989, available in LEXIS, Nexis Library ("Dar es Salaam Contacts are underway between the 
ren's Defense Fund motto: "Dear God, be good to me. The sea is so wide and my boat is so small." 299 But as the captain's comments convey, the children's problem, ironically, is that their vessels are so huge that they pose dangers to stowaways. ${ }^{300}$

Children asylum seekers are given special recognition in the Convention on the Rights of the Child ${ }^{301}$ which mandates that, with respect to a child who is seeking refugee status, signatories shall provide "co-operation in any efforts by the United Nations . . .

UN High Commission for Refugees, UNHCR, the national shipping agency company and the owners of a Greek vessel docked at Dar es Salaam port to determine the fate of three Somali teenagers discovered on board the cargo ship."); see also Treatment Protested, supra note 235, at 16 (reporting that a teenage boy arrived in Miami among a group of Haitian stowaways that was chained and caged aboard a cargo vessel); supra notes 167-68 and infra note 324 (describing incident in which two Ethiopian teenagers were sent from the United States to Gibraltar, even after they jumped ship twice).

${ }^{299}$ CDF REP. (Children's Def. Fund, Washington, D.C.), Dec. 1989, at 1; see also DAvid AdAM, The Edge OF GloRY: PRAYERS IN THE CELTIC TRADITION 33 (1985) (reciting similar language in the prayer of the Breton fishermen).

${ }^{900}$ Among UNHCR personnel, accounts of stowaways crushed or suffocated by cargoes abound. See, e.g., INS Grants Refuge to Vietnamese Stowaway, UPI REPORT, Oct. 31,1989 , available in LEXIS, Nexis Library (commenting on a stowaway who had made a plywood seat and lashed himself just above the ship's propeller, the captain noted that "if I filled the ballast he would be dead, if I didn't stop in Singapore [and run a lifeboat exercise during which the stowaway was spotted] he would be dead"); McAleenan, supra note 248, at 2 (noting that five stowaway children who were hiding in a locker for an anchor chain were particularly fortunate because "this particular anchor was not in use, or [else] they would have been 'scrambled eggs' "); Stowaways Killed, USA TODAY, June 20,1990, at 4A (reporting that 11 stowaways hidden in a cargo hold were killed by "a pesticide that was sprayed on the vessel's cargo of cocoa"); Two Stowaways Recount 3 Days of Terror in Freight Container, CHI. TRIB., July 7,1991 , at C19 (relating incident in which six stowaways suffocated in sealed freight container).

301 Convention on the Rights of the Child, Nov, 20, 1989, 28 I.L.M. 1456 [hereinafter Child Convention] (adopted without vote by U.N. General Assembly, G.A. Res. 25, U.N. GAOR, 44th Sess., 61st plen. mtg., Annex, U.N. Doc. A/Res/44/ 25 (1989)). At least seventy countries have now ratified it. See The Rights of the Child, HUM. RTS. NEwSL. (Centre for Human Rights, Geneva, Switz.), Jan. 1991, at 3; see also $i d$. at 2 (comment of Philip Alston, Professor of Law, that the Convention is uniquely comprehensive in that it "brings together, in one document, a statement of the rights of the child that were previously to be found only by searching through a score of different instruments in diverse areas such as juvenile justice, refugee law, humanitarian law, social welfare law, etc."); Gary B. Melton, Socialization in the Global Community: Respect for the Dignity of Children, 46 AM. PsYcHOL. 66, 70 (1991) ("The Convention is the first official bill of rights of children with a coherent, comprehensive vision of children's policy.'); of. Cynthia Price Cohen \& Hedwin Naimark, United Nations Convention on the Rights of the Child: Individual Rights Concepts and Their Significance for Social Scientists, 46 AM. PSYCHOL. 60, 60 (1991) ("Although the breadth of the Convention's protections is exceptional, what is especially interesting and innovative is the ultimate picture that the text draws of the child as an individual."). 
to protect and assist such a child and to trace the parents or other members of the family . . . in order to obtain information necessary for reunification with his or her family" and if family members cannot be found, the State must afford the child ${ }^{302}$ protection..$^{303}$

The preferred solution for child asylum seekers, under the Convention on the Rights of the Child, is family reunification. The UNHCR supports this policy and has been actively implementing it with respect to unaccompanied minors in Indochina. ${ }^{304}$ Serious problems, however, can arise when the child expresses a fear of persecution while the child's family, and sometimes the government of the country of origin, insist on her return and vow that the child will not face persecution. ${ }^{305}$ The government may be falsely assuring the international community of the child's safety while coercing the parents into asking for the return of their child by threatening the remaining family members. If the child comes from

302 Under the Convention, all persons under the age of 18 are considered children "unless, under the law applicable to the child, majority is attained earlier." Child Convention, supra note 301, art. 1, 28 I.L.M. at 1459.

${ }^{303} \mathrm{Id}$. art. 22, I 2, 28 I.L.M at 1465 (erroneously printed under art. 24). For a correct reprinting of this article, see BURNS H. WESTON, ET AL., BASIC DOCUMENTS IN INTERNATIONAL LAW AND WORLD ORDER 498, 503-04 (2d ed. 1990). Child asylum seekers also are protected by the more general provisions of the Convention. Article 2 requires that state parties "respect and ensure the rights set forth in the present Convention to each child within their jurisdiction without discrimination of any kind, irrespective of the child's status ...." Child Convention, supra note 301 , art. 2, I 1, 28 I.L.M. at 1459; see also Ilene Coln, The Convention on the Rights of the Child: What It Means for Children in War, 3 INT'L J. REFUGEE L. 100, 106 (1991) (maintaining that "UNHCR protection officers can and should assert [claims to all Child Convention rights] on behalf of refugee children").

${ }^{304}$ See Christine Mougne, The Tide is Tuming, RefugeEs, Dec. 1990, at 25 (stating that a Special Committee that decides on the cases of unaccompanied children has "placed particular emphasis on the principle of family reunification" and that hundreds of children have been returned to their families in Vietnam under UNHCR supervision). The UNHCR performs follow-up visits to the child's home to be assured of her well-being. See id.

${ }^{305}$ See, e.g., Young Stowaways Ask Asylum from Ethiopia, supra note 44, at B2, (reporting that two stowaway children insisted that they feared for their lives if returned to Ethiopia, even though their parents "had not indicated any fear that the boys would be harmed if they were returned" and a representative of the Ethiopian government had insisted that no punitive measures would be taken against them because, in his words, "[ $t]$ hey are small children, after all"). Reassuring statements by government officials can be troubling, particularly if the children come from a country like Ethiopia, whose government, until recently, forcibly conscripted children at an extremely young age. See generally 200,000 Youths Said to Be in World's Armies, N.Y. TIMEs, Aug. 7, 1988, $\S 1$, at 8 ("The world's armies include about 200,000 youths, some as young as 12 years of age ...."). 
a country with a poor human rights record, states should give specialized attention to the child's case. Furthermore, a party state must consider the child's opinion of her situation. ${ }^{306}$ To abide by these requirements, the state must disembark a stowaway child and trace her family to determine the best solution to her plight.

Stowaway children should also be granted at least temporary haven at the first port of call because children unaccompanied by parents may be reticent or may not be mature enough to express a fear of persecution. Effective investigation of the children's situation clearly requires disembarkation. One expert who treated children who had been kidnapped and recruited by Mozambican rebels when they were as young as six years old observed that these children were "psychologically numbed-often speechless, seemingly incapable of showing any kind of emotion other than a kind of unnerving, wait and see, stoicism. ${ }^{\text {307 }}$ These observations again raise the concern of asylum seeker reticence among those that have witnessed and experienced horror, a concern that is heightened when children are involved. The findings suggest that stowaway children must be disembarked immediately so they can tell their stories in a less intimidating forum to officials aware of their precarious psychological state. Other children may be too young to articulate a fear of persecution. In such cases, the UNHCR has urged that "objective factors such as the situation prevailing in the country of origin and the circumstances of family members there should be accorded greater weight." ${ }^{308}$

${ }^{306}$ See id. art. 12, 28 I.L.M. at 1461 ( ${ }^{(}(1)$ States Parties shall assure to the child who is capable of forming his or her own views the right to express those views freely in all matters affecting the child .... (2) For this purpose, the child shall in particular be provided the opportunity to be heard in any judicial and administrative proceedings .....").

${ }^{307}$ Neil Boothby, Living in the War Zone, WORLD REFUGEE SURVEY: 1989 IN REVIEW (U.S. Comm. for Refugees) 40, 41 (1990). Arn Chron Pond, a child during the Pol Pot years in Cambodia who was accorded refugee status by the United States, poignantly makes this point:

I have come to realize that $I$ am alive again. I am not just alive because bullets failed to reach my brain. I am not just alive because a stick missed my skull . . . . I am alive really only because finally and painfully after these years, I know that I can love again. I can feel the suffering of others, not just my own.

The World Seemed Strange, Silent and Slow to Move, WORLD REFugEe SURVEY: 1987 IN REVIEW (U.S. Comm. for Refugees) 13, 13 (1988); see also Margaret McCallin, The Convention on the Rights of the Child as an Instrument to Address the Psychological Needs of Refugee Children, 3 INT'L J. REFUGEE L. 82, 90 (1991) (describing the psychological impact of traumatic experiences on refugee children).

${ }^{308}$ Arthur E. Dewey, Refugee Children: Half the World's Refugees, REFUGEES, June 
Those countries, such as the United States, that are not parties to the Convention ${ }^{309}$ are still obliged to protect child asylum seekers because of their obligations under the 1951 Convention and the 1967 Protocol. ${ }^{310}$ Furthermore, these countries must recognize that "the Convention will rapidly-if it has not already-become the universal benchmark against which the performance of all countries with respect to the well-being of their children will be judged." ${ }^{111}$ The Convention is therefore in the process of becoming customary international law, which all nations are obliged to follow. 312

The United States, in particular, also has special obligations to child asylum seekers that have been imposed through common law. At least one federal court has determined that the "limited understanding and decision-making ability" of children and the "inherently coercive nature of INS processing require that the children be given some assistance in understanding their rights. "313 The court manclated that the INS ensure that children in its custody communicate with family members, friends, or with "an organization found on the free legal services list." 314 These special services are equally important in the child stowaway context,

\section{8 , at 16,17 .}

${ }^{309}$ The United States has signed but not ratified the Convention. It has argued that it cannot ratify the Convention because "it cannot see how to make its states comply, "while Great Britain, which also has not ratified the Convention, has stated that it has "trouble conforming to the convention's articles over immigration policy." Caroline Moorehead, Child Rights Campaign Starts Timidly; Rights and Wrongs, THE INDEPENDENT, Mar. 4, 1991, at 12, available in LEXIS, Nexis Library. Moorehead declared that "[t]he whole process [of implementing the Convention] becomes something of a mockery when apparently liberal democracies do not take part, while repressive regimes do." Id.

${ }^{310}$ See Cohn, supra note 303 , at 107 (noting that "all international treaties in force for a given state must be read together for maximum protection" of child asylum seekers).

311 The Rights of the Child, supra note 301, at 4; see also UNICEF, THE WORLD SUMMIT FOR CHILDREN 12 (1990) ("It is expected that the standards set by the Convention will become the point of reference for everyone concerned with the health, development and protection of children."); see also McCallin, supra note 307, at 83 (asserting that the Child Convention "represents world consensus on the minimum set of rights which governments must guarantee to children').

312 See supra note 271.

313 Perez-Funez v. INS, 619 F. Supp. 656, 664 (C.D. Cal. 1985); see also OrantesHernandez v. Meese, 685 F. Supp. 1488, 1509 (C.D. Cal. 1988) (including unaccompanied minors as a category of immigrants deserving enhanced protection), aff'd sub nom. Orantes-Hernandez v. Thornburgh, 919 F.2d 549 (9th Cir. 1990).

${ }^{314}$ Perez-Funez, 619 F. Supp. at 670. 
and if they are not feasible, immigration officials should at least be obligated to assist the child stowaway in contacting the UNHCR.

In sum, with the environment of renewed international commitment to children's rights, ${ }^{315}$ port states have become bound by customary international law and by treaty to shelter stowaway children, to assist them with family reunification and, if necessary, to grant them asylum. Countries, such as the United States, that have not ratified the Convention on the Rights of the Child should do so. Furthermore, any draft of a new stowaway convention should include provisions that recognize the special situation of stowaway children and mandate that nations provide special assistance to these asylum seekers.

\section{CONCLUSION}

To bring its policy regarding stowaways into compliance with its obligations under the 1967 Protocol and the Refugee Act of 1980, the U.S. Justice Department should amend its regulations regarding stowaways to require automatic disembarkation of all stowaways. Once they are disembarked, stowaways should not only have a right to an interview with the local district director and an asylum officer, if appropriate, but also the right to an exclusion hearing before an immigration judge, if asylum is denied at the district director level. To implement these changes, 8 C.F.R. $\$ 253.1(f)(1)$ should be amended to read: "( 1 ) If the alien is on a vessel or other conveyance, she shall be promptly removed from the conveyance." Removal from the vessel should not hinge, as it currently does, on whether an alien "makes [her] fear of persecution known to an immigration inspector or other official making an examination on the conveyance." ${ }^{\text {816 }}$ After removal, a stowaway should have the right to an interview with the district director, and the opportunity to file for asylum. If a stowaway alleged a fear of persecution to the district director, she would then have the right to have her application reviewed by an asylum officer, as is currently required. ${ }^{317}$

315 The World Summit for Children was held at the United Nations on Sept. 30, 1990. "For an entire day the chiefs rumbled and rhapsodized over the plight of ... children." Samuel Francis, Son of New World Order, WASH. Times, Oct. 24, 1990, at G2. One can only hope that "[a] successful World Summit [will] make the 1990s the decade in which the shameful large-scale deaths and widespread malnutrition of the world's children are consigned to history." UNICEF, GIVING CHILDREN A FUTURE: THE WORLD SUMMTT FOR CHILDREN 9 (1990).

${ }^{316} 8$ C.F.R. § 253.1(f)(1) (1991).

317 See id. $\$ 253.1(\mathrm{f})(2)$. 
Mandatory disembarkation would not translate into an assumption that all stowaways are asylum seekers. ${ }^{318}$ If the stowaway did not allege a fear of persecution once disembarked and given adequate time to relate her history (with the assistance of an interpreter) to the district director and/or asylum officer, she could then be returned to the custody of the shipping line and removed from the United States.

The right to appeal a negative asylum decision at the district director level, 8 C.F.R. $\$ 253.1(f)(4)$, should also be amended to read:

(4) A decision denying asylum to an alien crewman or stowaway, but not an alien temporarily excluded under section 235(c) of this chapter, may be appealed directly to a special inquiry officer (immigration judge). Such appeal must be filed within ten days of the asylum officer's decision. From a decision of a special inquiry officer denying asylum, such alien may then file, within ten days of the special inquiry officer's decision, an appeal to the Board of Immigration Appeals.

Currently, the regulation denies stowaway asylum seekers the intermediate level of appeal to an immigration judge. ${ }^{319}$

Finally, the regulations should be amended to enable full UNHCR participation. Presently, under 8 G.F.R. § 208.6(a), “[a]n application for asylum or withholding of deportation shall not be disclosed except as permitted by this section, or at the discretion of the Attorney General, without the written consent of the applicant." ${ }^{\text {820 }}$ The section enumerating the exceptions to the $\S$ 208.6(a) disclosure limitations, 8 C.F.R. $\$ 208.6(c)$, should be amended to include the UINHCR among the exceptions. The new 8 C.F.R. $\$ 208.6$ (c)(3) could read: “(c) This section shall not apply to any disclosure to: (3) the United Nations High Commissioner for Refugees (UNHCR)." This change would be a recognition of the fact that the UNHCR is an inter-governmental organization with which the United States has agreed to cooperate on asylum matters. The current rules incorrectly categorize the UNHCR as a nongovernmental organization.

${ }^{318}$ Clearly, not all stowaways are meritorious asylum applicants; some are outright criminals. See, e.g., Tucked Above a Rudder: 2 Men and Cocaine, N.Y. TIMES, Jan. 29, 1991 , at $\mathrm{A} 1$ (reporting that police divers in the New York harbor discovered two stowaways with 366 pounds of cocaine in the air pocket of the rudder compartment on an oil tanker). Other stowaways are simply immigrants.

${ }^{319}$ See 8 C.F.R. \$ 253.1(f)(4) (1991).

${ }^{320} 8$ C.F.R. § 208.6(a) (1991). 
Congress and the Justice Department must realize that the current procedures for stowaway asylum seekers violate international law. The Justice Department should be pressured into action. While the Attorney General has the authority to "establish such regulations . . . as he deems necessary for carrying out his authority under the provisions"321 of the INA, these regulations clearly "cannot conflict with either the letter or the spirit of the Act unless [they] ha[ve] been authorized by some specific statutory directive." ${ }^{322}$ Congress has not authorized the Attorney General to distinguish among asylum seekers by according different groups of asylum seekers different rights; on the contrary, under INA § 208, the Attorney General is ordered to establish equal procedures for all asylum seekers "irrespective of such alien's status." ${ }^{\text {"323 }}$ If the Justice Department is unwilling to implement the above-suggested rules, Congress should intervene and amend the INA to accord similar rights to all stowaway asylum seekers.

If neither Congress nor the Attorney General amends the procedures for stowaways to require automatic disembarkation, the regulations should at least be amended to require that an asylum officer conduct the shipboard screening interview, accompanied by a qualified INS interpreter. The regulations should also require shipmasters to notify the UNHCR of a stowaway's presence, and should allow attorneys appointed by the UNHCR immediate access to the stowaway. Section 253.1(f)(1) could read:

(1) If the alien is on a vessel or other conveyance, an asylum officer and INS interpreter shall conduct a screening interview of such alien. If an attorney sent by UNHCR is ready and willing to assist the stowaway, she shall be permitted to board the vessel along with the asylum officer and interpreter. If the alien makes a fear of persecution known to the asylum officer, she shall be promptly removed from the conveyance.

The previous suggestions for amending 8 G.F.R. $\S 253.1(f)(4)$, regarding the right to appeal asylum decisions, and 8 C.F.R. $\S 208.6(\mathrm{c})$, regarding release of information about asylum applicants to the UNHCR, would still apply in the above alternative. In this situation, an additional section requiring notification of the UNHCR by shipmasters, in addition to their present duty to notify the INS

321 INA § 103(a), 8 U.S.C. § 1103(a) (1988).

322 Sannon v. United States, 427 F. Supp. 1270,1275 (S.D. Fla. 1977), vacated without opinion, 566 F.2d 104 (5th Cir. 1978).

${ }^{323}$ INA § 208(a), 8 U.S.C. § 1158(a) (1988). 
under 8 C.F.R. $\S \S 231.1(a), 251.1$ (a), would have to be added to 8 C.F.R. $\S 253.1$. At the same time, it would be helpful if the UNHCR facilitated the task of the pro bono attorney by releasing documents to the attorney prior to the stowaway's arrival. To safeguard the stowaway's privacy interest, the UNHCR could secure a written agreement from the attorney regarding the use of the information.

With respect to all of the above alternatives to mandatory disembarkation, if the Attorney General does not implement them, Congress could again implement similar requirements by statute. If the United States refuses to implement any of the above suggestions by statute or regulation, its cursory treatment of stowaways will continue to be in violation of international and domestic law. By forcing the stowaway to languish aboard the vessel and ultimately possibly sending her back to persecution, the United States would be directly responsible for her fate. A U.S. policy that accords stowaways rights equivalent to those of other asylum seekers would enable the United States to take the lead in policy changes toward stowaways on an international level.

If the United States implemented fair procedures for stowaways, it could then organize a draft committee for a new stowaway convention under the auspices of the United Nations. It would be most practical for such a convention to rest ultimate responsibility for a stowaway with the port state, not the flag state. Furthermore, such a convention should include a provision mandating special protection for stowaway children, and another section calling for all shipmasters to notify the UNHCR whenever a stowaway is discovered. In the interim, the United States could take the lead in protecting stowaways in the international arena by ratifying the 1957 International Convention Relating to Stowaways; with a tenth ratifying country, this Convention would go into effect and stowaways would have at least some protection internationally.

If the Justice Department shirks its duties, it will have to cope with the damage to its public image when a stowaway is unjustifiably expelled, or manages to get off the vessel through habeas proceedings or by swimming ashore. Attempting to justify to both the public and Congress why a stowaway was expelled to face persecution or drowned while attempting to swim ashore, would be more administratively burdensome than simply letting stowaways off their vessels, especially since shipping companies, not the U.S. government, must pay for a stowaway's detention. The media is always 
quick to learn of a stowaway's plight, ${ }^{324}$ and members of Congress are very sympathetic to stowaways imprisoned on their vessels. ${ }^{325}$ Furthermore, if a stowaway is returned to persecution or dies, Congress would not hesitate to investigate. ${ }^{326}$

In sum, according stowaways greater rights is not only required by international and domestic law, but is also a wise policy decision. Those who would hesitate to grant stowaways greater rights must recall that the very act of stowing away is a desperate move; the

324 When a teenage Ethiopian stowaway jumped ship, for the second time, on July 4, 1990 in Morehead City, North Carolina and attempted to swim four miles to shore, the local news immediately reported his story. He was missing for two days and presumed drowned, but luckily, after he had swum two miles, he managed to hoist himself onto the anchor of a U.S. Navy vessel. The U.S. authorities simply returned him to his vessel. Because this vessel never made it into port, the stowaway child headed off with the vessel to the next port of call, Gibraltar. See supra notes 167-68. A hauntingly similar situation arose this summer when two stowaway asylum seekers "jumped into the ocean about a mile from Miami Beach ... and tried to swim to shore. [They] were returned to the ship from [INS] custody and were chained to the deck.... As news of their treatment spread in Miami's Haitian-American community, a crowd gathered at the docks to jeer officials." See Treatment Protested, supra note 235 , at 16.

In another incident, a television reporter in New Orleans

received a tip that 16 Jamaican stowaways had been hosed down in their cells by harbor police on a night when it was 40 degrees. Several had to be hospitalized for chills and fever. After [the reporter's] report, the FBI began investigating. When it was learned the stowaways were to be shipped back to Jamaica, [the reporter] chartered a helicopter and found the barge carrying the stowaways downriver. After calls to authorities, the barge was stopped and the stowaways taken into custody. A federal grand jury [was] investigating the incident.

Local TV Joumalism; Special Report, INFORMATION ACCESs Co., Aug. 26, 1985, available in LEXIS, Nexis Library. The barge was "intercepted by agents of the [FBI], the Coast Guard, and the INS" and the incident led to the Lynch litigation, described supra note 243.

${ }^{325}$ See David Lyons \& Lizette Alvarez, Haitians Lose Appeal to Stay, MIAMI HERALD, July 30, 1991, at 2B (reporting that allegations of mistreatment of several stowaways "prompted U.S. Sen. Bob Graham, D-Fla., to ask U.S. Attorney General Richard Thornburgh to investigate the incident in Miami, as well a similar one in Tampa. Graham stated that '[t]he actions of both ships' crews that resulted in Haitians being shackled, chained and caged are despicable." ); Vietnam Stowaway Granted Asylum, supra note 287, at A27 (reporting that, after being denied asylum in several ports, a stowaway who had landed in Providence, Rhode Island was granted asylum by the INS "after lobbying by Sen. Claiborne Pell (D-R.I.) and other members of the Rhode Island congressional delegation"). In another incident, staff members in Sen. Jesse Helms's office assisted the author during July 1990 in locating an attorney willing to assist the two Ethiopian stowaways on their vessel near the Morehead City port. See supra notes 167-68.

326 The myriad hearings concerning the forcible return of the seaman Medvid attest to this assertion. See supra notes 66-67, 122. 
image of a stowaway detained aboard an enormous vessel, moving hopefully from port to port, yet being denied entry at each stop (as well as perhaps ultimately being returned to persecution) should provide sufficient motivation for action. 